\title{
Entidades de abrigo de crianças e adolescentes do município de Vitória - ES: aproximação de uma realidade social
}

\section{Mônica Gomes Pereira Tosta}

Dissertação apresentada ao Programa de Pós-Graduação em Saúde Pública da Faculdade de Saúde Pública da Universidade de São Paulo para obtenção do título de Mestre em Saúde Pública.

Área de Concentração: Serviços de Saúde Pública

Orientadora: Profa. Dra. Maria Cecília Focesi Pelicioni

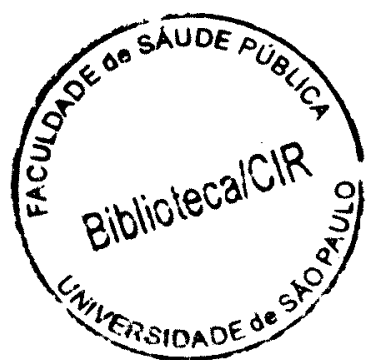


Autorizo, exclusivamente para fins acadêmicos e científicos, a reprodução total ou parcial desta dissertação, por processos fotocopiadores. Ao usá-lo, cite a fonte.

Assinatura:

Data:

$$
45665 / 2005 \text { doc }
$$


Dedico este trabalho aos meus pais, Marina e Ariovaldo, ao meu irmão, Alexandre, ao meu marido, Cláudio, e às minhas amadas filhas, Natália e Lorena, por me proporcionarem a felicidade da vida em família.

Aos que vivem sem as suas famílias. 


\section{AGRADECIMENTOS}

A Deus

Aos meus pais, Marina Gomes Pereira e Ariovaldo Pereira

Ao meu marido, Cláudio Alexandre Tosta

Às minhas filhas, Natália Pereira Tosta e Lorena Pereira Tosta

À minha orientadora, Professora Dra. Maria Cecília Focesi Pelicioni

Ao Professor Dr. João Alvécio Sossai

Aos Professores Dr. Paulo Capel Narvai e Dr. Roberto Augusto Castellanos Fernandez

Às Professoras Dra. Fumika Peres e Dra. Roseli Fischmann

A todos os docentes do Mestrado Interinstitucional em Saúde Pública

Aos colegas de turma do Mestrado Interinstitucional em Saúde Pública

À Diretora do CAIJ/MPES, Dra. Patrícia Calmon Rangel Teixeira

Ao Diretor Geral da FAESA, Professor Alexandre Nunes Theodoro

À Assistente Social Mara Regina Trés Altoé Filgueiras

Às Psicólogas Fernanda Rossi e Aline Bernardes Bastos de Oliveira

À Professora Dra. Edinete Maria Rosa

Às acadêmicas de Psicologia Camila S. Nogueira, Maria Thereza R. Borges e Naitê

R. Monteiro

À Biblioteca da FSP/USP, na pessoa da profissional Gisele Luiza Cano

À Biblioteca da FAESA Campus II, na pessoa da Bibliotecária Virgínia Maria Kretli de Castro e das profissionais Alessandra M. Patuzzo, Denúzia G. R. Martins, Gleides Maria Martins e Melayne B. Azevedo

À Professora Ms. Patrícia Lima Peres

À acadêmica de Comunicação Social Thaiza Rodrigues Mota

Ao Professor Márcio Kill

À responsável e aos trabalhadores da entidade de abrigo do município de Vila Velha, onde foi realizado o pré-teste do instrumento de pesquisa

Às responsáveis e aos trabalhadores das entidades de abrigo do município de VitóriaES

Às crianças e aos adolescentes institucionalizados no município de Vitória-ES

A todos que direta ou indiretamente contribuíram para a realização deste trabalho 


\section{RESUMO}

Tosta MGP. Entidades de abrigo de crianças e adolescentes do município de Vitória - ES: aproximação de uma realidade social. São Paulo; 2004. [Dissertação de Mestrado - Faculdade de Saúde Pública da USP].

Trata-se de um estudo descritivo, de caráter exploratório, sobre o perfil, a formação educacional e a realidade de trabalho dos profissionais em exercício nas sete entidades de abrigo existentes no município de Vitória-ES e os seus possíveis reflexos na vida das crianças e adolescentes institucionalizados. Discutiu-se a problemática do abandono, da violência familiar e da institucionalização de crianças e adolescentes, realizando-se uma abordagem histórica das medidas de proteção destinadas às crianças. Foram mencionadas as legislações que garantiam os direitos das crianças e adolescentes e destacada a importância do convívio familiar, na promoção de um desenvolvimento saudável e no processo de formação dos indivíduos, assim como na sua inserção social. Os dados foram coletados por meio da aplicação de entrevistas semi-estruturadas a 67 profissionais, em seus locais de trabalho, no período de setembro a dezembro de 2003. Para caracterizar as crianças e adolescentes institucionalizados em um dado momento histórico, utilizaram-se dados secundários do último levantamento do Centro de Apoio Operacional da Infância e da Juventude (CAIJ) do Ministério Público do Estado do Espírito Santo, realizado de outubro a dezembro de 2002. Verificou-se a necessidade de implantação de um programa de qualificação e de educação continuada para os profissionais das entidades de abrigo. Sugeriram-se algumas formas de participação dos diversos segmentos da sociedade, de modo a contribuir com a qualidade da atenção destinada às crianças e adolescentes institucionalizados e apresentou-se uma proposta de curso de formação básica para os profissionais.

Descritores: Entidade de abrigo. Institucionalização de criança e adolescente. Qualificação profissional. 


\section{SUMMARY}

Tosta MGP. Entidades de abrigo de crianças e adolescentes do município de Vitória - ES: aproximação de uma realidade social. [Children's and teen's homes in the county of Vitória - ES: approximation of a society's reality]. São Paulo (BR); 2004. [Essay of a Master Degree - Faculdade de Saúde Pública da Universidade de São Paulo Brazil].

It is about a descriptive study, with exploratory character, of the profile, the educational background and the reality of the professionals working at seven homes in the county of Vitória - E.S., besides its possible results in the lives of the related children. The problems concerning the abandon, the familiar violence and the insertion of these children and teenagers have been discussed. A historical approach of the protection actions concerning children has been made. It has been mentioned the law that preserve teen's and children's rights as well as the importance of living with the family with the purpose of healthy development in an individual growth and their insertion onto society. Data was collected in semi-structured interviews with 67 professionals in their working environment, from september to december 2003. So that the intern children and teens could be refered to in a certain historical spot, secondary data of the latest research - october to december 2002 - from "Centro de Apoio Operacional da Infância e da Juventude" - (CAIJ) - Childhood and Youth Operation Support Center, in the state of Espírito Santo - have been used. From that, the need for a professional's qualification and educational programm has appeared. The participation of several segments of society has been suggested with the purpose of improving the quality of the attention towards intern children and teens. Also, the proposition of a basic course for the professionals has been presented.

Contents: Homes. Insertion of children and teens. Professional improvement. 


\section{ÍNDICE}

1. APRESENTAÇÃO 1

2. INTRODUÇÃO 4

3. REVISÃO DA LITERATURA $\quad 8$

3.1 Histórico das medidas de proteção às crianças e legislação pertinente 8

$\begin{array}{lll}3.2 & \text { Família e violência familiar } & 19\end{array}$

3.3 Institucionalização de crianças e adolescentes 27

3.4 Trabalhadores das entidades de abrigo e formação de educadores 33

4. OBJETIVOS 42

5. DEFINIÇÃO DE TERMOS

6. METODOLOGIA 44

7. ANÁLISE E DISCUSSÃO DOS RESULTADOS 48

$\begin{array}{lll}7.1 & \text { Capacidade instalada e distribuição dos trabalhadores } & 48\end{array}$

$\begin{array}{lll}7.2 & \text { Crianças e adolescentes institucionalizados } & 49\end{array}$

$\begin{array}{lll}7.3 & \text { Identificação dos abrigos } & 55\end{array}$

7.3.1 Sobre as responsáveis $\quad 56$

7.3.2 Sobre o abrigo 56

$\begin{array}{lll}\text { 7.3.3 Sobre o plano de trabalho } & 61\end{array}$ 
$\begin{array}{lll}7.4 & \text { Trabalhadores das entidades de abrigo } & 77\end{array}$

$\begin{array}{ll}\text { 7.4.1. Informações sobre saúde } & 90\end{array}$

7.4.2. Informações sobre o trabalho desenvolvido nos abrigos 97

$\begin{array}{ll}\text { 7.4.3. Programa de educação continuada } & 111\end{array}$

8. CONCLUSÕES 115

$\begin{array}{ll}\text { 9. CONSIDERAÇÕES FINAIS } & 121\end{array}$

10. SUGESTÕES 122

11. REFERÊNCIAS 126

\section{ANEXOS}

Anexo 1 - DECLARAÇÃO UNIVERSAL DOS DIREITOS DA CRIANÇA Al

Anexo 2 - ROTEIRO DE ENTREVISTA PARA RESPONSÁVEIS A3

Anexo 3 - ROTEIRO DE ENTREVISTA PARA FUNCIONÁRIOS A7

$\begin{array}{ll}\text { Anexo } 4 \text { - PROPOSTA DE CURSO A10 } & \end{array}$ 


\section{LISTA DE FIGURAS}

Figura 1: Capacidade instalada, por abrigo 48

Figura 2: Distribuição dos entrevistados, por abrigo 49

Figura 3: Número de crianças e adolescentes institucionalizados, por sexo

Figura 4: Número de crianças e adolescentes, por faixa etária 52

Figura 5: Número de crianças e adolescentes, por idade, na data da institucionalização

Figura 6: Distribuição das crianças e adolescentes, por tempo de institucionalização

Figura 7: $\quad$ Participação dos trabalhadores na avaliação da situação das crianças e adolescentes

Figura 8: Participação dos entrevistados no programa de preparação para o desligamento das crianças e adolescentes $\quad 74$

Figura 9: Número de trabalhadores das entidades de abrigo, por sexo

Figura 10: Participação das crianças e adolescentes na execução das tarefas diárias do abrigo, segundo depoimento dos entrevistados

Figura 11: Número de entrevistados, por situação trabalhista

Figura 12: Grau de satisfação dos entrevistados com o trabalho que desenvolviam no abrigo

Figura 13: Percepção dos trabalhadores, em relação ao seu desenvolvimento profissional dentro do abrigo

Figura 14: Percepção da necessidade de desenvolvimento de um programa de educação continuada 


\section{LISTA DE QUADROS}

Quadro 1: Organização dos abrigos quanto ao público atendido, por sexo e faixa etária

Quadro 2: Categorias profissionais constantes no quadro de funcionários dos abrigos

Quadro 3: Categorias profissionais dos voluntários que atuavam nos abrigos

Quadro 4: Tipos de atendimento realizados fora das entidades de abrigo

Quadro 5: Participação na elaboração do Plano de Trabalho dos abrigos

Quadro 6: Formas de recepção e acolhimento das crianças e adolescentes

Quadro 7: $\quad$ Outros cursos freqüentados pelos trabalhadores dos abrigos

Quadro 8: Temas sugeridos para um curso de educação continuada 


\section{LISTA DE TABELAS}

Tabela 1: Forma de participação dos entrevistados na avaliação da situação das crianças e adolescentes

Tabela 2: $\quad$ Motivos da falta de participação na avaliação da situação das crianças e adolescentes alegados pelos entrevistados

Tabela 3: Formas de participação dos entrevistados no acolhimento de crianças e adolescentes

Tabela 4: Forma de participação dos trabalhadores na preparação para o desligamento das crianças e adolescentes

Tabela 5: Distribuição dos trabalhadores dos abrigos, por faixa etária

Tabela 6: Distribuição dos trabalhadores, segundo a função que exerciam nos abrigos

Tabela 7: Tempo de exercício da função nos abrigos

Tabela 8: Atividades desenvolvidas pelos trabalhadores nos abrigos

Tabela 9: Formas de participação das crianças e adolescentes na execução das tarefas diárias do abrigo

Tabela 10: Freqüência com que os trabalhadores tinham contato com as crianças e adolescentes

Tabela 11: Grau de instrução dos entrevistados

Tabela 12: Cursos freqüentados pelos trabalhadores

Tabela 13: Significado de saúde para os entrevistados

Tabela 14: Principais queixas das crianças e adolescentes em relação à saúde fisica

Tabela 15: Principais queixas das crianças e adolescentes em relação às questões afetivas

Tabela 16: Postura dos trabalhadores diante dos problemas relatados pelas crianças e adolescentes 
Tabela 17: Problemas de saúde que as crianças e adolescentes mais apresentavam, na opinião dos entrevistados

Tabela 18: Formas de contribuição para a manutenção da saúde das crianças e adolescentes, na opinião dos trabalhadores

Tabela 19: Opinião dos 67 trabalhadores entrevistados, em relação à situação do abrigo

Tabela 20: Dificuldades encontradas no exercício da função, segundo relato dos entrevistados

Tabela 21: Causas das dificuldades encontradas no exercício da função, de acordo com os entrevistados

Tabela 22: Sugestões dos entrevistados para melhorar as condições de trabalho

Tabela 23: Opinião dos entrevistados sobre o seu relacionamento interpessoal no ambiente de trabalho

Tabela 24: Opinião dos trabalhadores sobre as relações interpessoais com as crianças e adolescentes

Tabela 25: Motivos que levaram os entrevistados a trabalharem em um abrigo

Tabela 26: Motivos que mantêm os entrevistados trabalhando em um abrigo

Tabela 27: Conhecimentos que gostariam de adquirir para melhorar a execução das suas atividades 


\section{APRESENTAÇÃO}




\section{APRESENTAÇÃo}

Esta breve apresentação tem por objetivo situar o leitor no contexto que levou a autora a se interessar pela questão da institucionalização de crianças e adolescentes, das entidades de abrigo e de seus trabalhadores, além de informá-lo sobre as importantes parcerias que foram estabelecidas para que se obtivesse êxito na presente pesquisa.

A autora graduou-se em Odontologia e, por interessar-se mais especificamente por questões relacionadas à saúde das crianças e à problemática social, aprofundou seus estudos, em nível de pós-graduação, nas áreas de Odontopediatria e Odontologia em Saúde Coletiva. Trabalhou em Unidade Básica de Saúde em Brasília, durante cinco anos e meio, onde atuou como cirurgiã-dentista e, por duas oportunidades, foi chefe interina da mesma Unidade. Atuou em clínica particular por um período de oito anos. Ainda em Brasília, foi docente em curso de graduação de Odontologia, nas disciplinas de Odontopediatria e Clínica Integrada.

Ao vir residir no Estado do Espírito Santo, em 1997, passou a atuar como profissional administrativa em uma instituição de ensino superior, onde participou, tanto da elaboração, como da supervisão, de projetos de cursos de graduação, além de viabilizar convênios e parcerias para a realização das atividades práticas e de estágio dos referidos cursos, e, atualmente, trabalha na coordenação adjunta do Centro de Pós-Graduação. Na mesma instituição, atuou como docente da disciplina de Odontologia Social e Preventiva, realizando atividades de campo junto à comunidade. A conjugação de trabalho administrativo e docente fez surgir a necessidade de conhecimentos mais específicos na área de educação, o que levou a autora a freqüentar um curso de pós-graduação em Psicopedagogia.

A experiência educacional, profissional e pessoal tornou-se mais completa com a oportunidade de poder realizar, no curso de Mestrado em Saúde Pública, um trabalho que pudesse incluir aspectos sobre educação e saúde, sobretudo em um 
Com a pesquisa pretendeu-se caracterizar as entidades de abrigo, contextualizar a realidade de trabalho e identificar o perfil, a qualificação profissional e as opiniões sobre saúde das pessoas responsáveis pela educação e pelos cuidados das crianças e adolescentes institucionalizados, no município de Vitória - ES.

Para obter acesso e permissão para realizar uma investigação em entidades supervisionadas pelo Poder Jurídico do Estado, a pesquisadora buscou o apoio do Ministério Público do Estado do Espírito Santo (MPES), por meio da Direção do Centro de Apoio Operacional da Infầncia e da Juventude (CAIJ).

Na oportunidade, a equipe técnica do CAIJ estava em fase de elaboração de um projeto de pesquisa que, coincidentemente, tinha por objetivo investigar as características dos abrigos e suas propostas didático-pedagógicas, além de observar a estrutura fisica dos mesmos.

Compreendendo que as pesquisas se complementavam, a Direção do CAIJ propôs que os instrumentos de pesquisa fossem unidos e que ambas acontecessem como uma única pesquisa. A autora entendeu que a ampliação do estudo permitiria uma melhor visão e compreensão do contexto que envolvia o tema e que em nada prejudicaria o enfoque pretendido, pois os objetivos iniciais seriam respeitados e, ainda, enriquecidos.

Devido ao conhecimento técnico e à experiência na área, o CAIJ disponibilizou a Assistente Social de seu quadro de funcionários e uma estagiária para participarem da pesquisa.

Também participou da pesquisa, como voluntária, a Psicóloga que trabalhava em um dos abrigos e que já fazia parte do grupo de pesquisa do CAIJ. 
O estudo contou, ainda, com o apoio da instituição de ensino superior em que a autora trabalha, por perceber-se que, em um futuro próximo, a instituição poderá colaborar por meio da realização de projetos e de medidas educativas, cumprindo, assim, um importante e fundamental papel social.

A instituição colaborou, também, com a disponibilização de uma professora que, além de Psicóloga, ministrava a disciplina Metodologia de Pesquisa, e de três estagiárias, estudantes de Psicologia, que participaram como entrevistadoras e colaboraram na organização dos resultados.

A autora entendeu este trabalho como um ponto de partida para possíveis ações a serem realizadas na área da infância e da juventude e na área de formação de educadores, pois consistiu no primeiro estudo dessa amplitude realizado em entidades de abrigo do município de Vitória - ES e, também, do estado do Espírito Santo.

Agradeço a todos que oportunizaram e colaboraram para a realização deste estudo, que tanto me fez crescer como ser humano.

Mônica Gomes Pereira Tosta 


\section{INTRODUÇÃO}




\section{INTRODUÇÃO}

As crianças, desde os primeiros anos de sua vida, necessitam de atenção, contato físico e carinho para o seu bom desenvolvimento físico e mental. As condições de vida, os cuidados, a proteção, o amor, a orientação e a compreensão que recebem influenciarão diretamente na sua formação e na sua qualidade de vida e saúde, inclusive mental.

Para suprir suas necessidades, crianças precisam conviver num ambiente familiar sadio, que deve ser preferencialmente o das famílias nas quais nasceram (famílias naturais). No entanto, nos casos de impossibilidade de mantê-las inseridas nas suas famílias naturais, ou na ausência destas, é importante que as funções de atendimento sejam delegadas às famílias substitutas, como previsto no Estatuto da Criança e do Adolescente.

Todavia, nem sempre esse encaminhamento é possível, seja por impedimento jurídico ou outros, tais como mitos ou preconceitos da sociedade. Neste caso, crianças privadas de sua rede familiar são encaminhadas para entidades de abrigo onde deveriam permanecer por um curto espaço de tempo, mas, dependendo das circunstâncias, podem ficar até que se tornem adultas.

Desse modo, por mais bem estruturados que sejam os abrigos, pelo fato de oferecerem uma assistência em massa, dificilmente poderão suprir a atenção e o carinho que podem ser proporcionados por uma família, natural ou substituta.

Diante desse contexto, os efeitos da privação do convívio familiar na vida de crianças e adolescentes merecem atenção, pois esses indivíduos, independentemente de qualquer decisão técnico-jurídica, continuam carregando dentro de si necessidades físicas, psicológicas e sociais, além de sonhos e expectativas, características dessa faixa etária. Agregam-se a isso os sentimentos gerados pela própria situação de rejeição, como o pessimismo e a baixa auto-estima, entre outros. 
Assim, na tentativa de atender às necessidades de crianças e adolescentes, torna-se importante que eles sejam estimulados a participarem das atividades do cotidiano de um lar, incluindo alimentação, higiene, educação, religiosidade, responsabilidade e sociabilidade.

Para que a permanência de crianças e adolescentes seja adequada, é de fundamental importância que os profissionais responsáveis pelo cuidado e educação deles tenham envolvimento e qualificação suficientes para colaborarem com a formação de indivíduos saudáveis, educados, responsáveis, honestos, independentes, sociáveis, de bom caráter, com identidades próprias e felizes, além prepará-los para a vida em sociedade.

A literatura consultada demonstrou que, apesar de um passado histórico de desvalorização das crianças, já há muitos anos se tem se buscado implementar medidas sociais, educacionais e jurídicas com a finalidade de protegê-las, muito embora, repetidamente, fatores políticos e econômicos, entre outros, tenham dificultado o sucesso das ações.

Mesmo diante da relevância do tema, existem poucos trabalhos que tratam especificamente da questão de crianças e adolescentes institucionalizados e, também, do exercício profissional dos trabalhadores de entidades de abrigo.

No entanto, é imperiosa a necessidade de se desenvolver ações sociais e educacionais em benefício de crianças e adolescentes, principalmente aqueles que vivem em situação de risco social, de modo a oferecer condições para alterarem os rumos de suas vidas. Paralelamente, é também importante o apoio a famílias carentes de modo que possam manter os filhos sob seus cuidados, em condições dignas.

Mas, para que haja ação, há necessidade de planejamento, e para tornar possível um planejamento eficiente e responsável, é preciso que existam informações para embasá-lo. 
Como não foi localizado estudo realizado nesse campo, no município de Vitória e no Estado do Espírito Santo, pretendeu-se, com este trabalho, buscar dados que retratassem a situação existente nas entidades de abrigo da capital capixaba, de modo a fornecer subsídios para futuros estudos e planejamento de ações.

Vale ressaltar que a aproximação de entidades de abrigo precisa ser cuidadosa e respeitosa, pois são locais onde coexistem histórias de vida marcadas por sofrimentos e perdas, receios, insegurança, sonhos e desejos, esperanças, muitas vezes frustradas. Soma-se a isso, o fato dos abrigos serem observados, para não dizer, fiscalizados, pelo poder público. Assim, a complexidade dessa realidade faz com que, muitas vezes, os envolvidos não desejem falar sobre o assunto, principalmente, com pessoas de fora do seu círculo de relacionamento. E, ainda, dependendo da forma de abordagem e do propósito, o acesso às entidades pode ser negado, pelos responsáveis.

Sendo assim, tem-se a consciência das limitações do estudo, pois não foi possível observar a rotina diária das entidades, por um tempo suficiente para se chegar a outras conclusões, além das relatadas nos próximos capítulos, e, também, as conversas com as crianças e adolescentes não foram aprofundadas.

Entende-se que outras investigações sobre o tema devam ocorrer, mas após se conquistar a confiança das pessoas, por meio de um real envolvimento com as questões que lidam com suas vidas pessoais, no caso dos institucionalizados, e na vida profissional, no caso dos trabalhadores.

Este estudo foi norteado pelo Estatuto da Criança e do Adolescente (ECA), seguindo suas orientações quanto às medidas de proteção em abrigos, buscando-se verificar se os direitos garantidos e, sobretudo, se as necessidades físicas, psíquicas e sociais das crianças e adolescentes institucionalizados, de alguma forma, estavam sendo atendidos. 
Considerou-se importante investigar o tempo que as crianças e adolescentes têm permanecido privados do convívio familiar, as situações sociais, educacionais, familiares e de saúde desses indivíduos, por entender-se que são aspectos muito relevantes durante a fase de desenvolvimento, que refletirão, futuramente, na vida adulta.

Pretendeu-se, ainda, verificar o perfil, a qualificação profissional, a realidade de trabalho dos profissionais em exercício nas entidades de abrigo do município de Vitória - ES e a satisfação deles em relação às atividades desenvolvidas, além de suas opiniões sobre a saúde das crianças e adolescentes e a participação na vida dos mesmos. A intenção foi analisar se esses trabalhadores estavam preparados para o cumprimento da missão de cuidar e educar crianças e adolescentes, em situação de risco social.

Mesmo tratando-se de uma primeira aproximação, considera-se que as informações levantadas poderão fundamentar ações educacionais e, por conseqüência, sociais.

A revisão da literatura, apresentada no capítulo seguinte, busca contextualizar a temática para, em seguida, serem apresentados os resultados alcançados. 
REVISÃO DA LITERATURA 


\section{REVISÃO DA LITERATURA}

Neste capítulo, buscou-se inserir o tema da institucionalização de crianças e adolescentes, ressaltando-se a necessidade de preparar educadores para trabalhar em entidades destinadas a protegê-los, cuidá-los e educá-los, durante o período em que necessitam permanecer afastados de suas famílias.

O passado histórico, embora não tenha sido o foco da pesquisa, e seja, aqui apresentado, de forma breve e objetiva, auxiliou na compreensão da origem dos problemas de abandono, adoção e institucionalização de crianças.

Destacaram-se os documentos e legislações que garantem os direitos das crianças e adolescentes, com maior ênfase para a Declaração Universal dos Direitos da Criança, a Constituição Federal de 1988, o Estatuto da Criança e do Adolescente (ECA) e a Lei Orgânica da Assistência Social (LOAS).

Procurou-se mostrar o importante papel da família no processo de desenvolvimento e na saúde do indivíduo, e as consequêencias negativas, no caso de negligência e/ou violência familiar, que podem culminar com a institucionalização de crianças e adolescentes.

Por fim, porém não menos relevante, abordou-se a situação dos trabalhadores das entidades de abrigo, ressaltando-se as questões relativas à formação desses recursos humanos.

\subsection{Histórico das medidas de proteção às crianças e legislação pertinente}

A retrospectiva histórica mostra que as crianças foram vítimas da desvalorização ao longo de muitos anos, não se limitando àquelas das famílias menos favorecidas, mas, também, incluindo as das famílias mais ricas (SANTANA 2000). 
Segundo a autora, cabia ao pai a decisão de aceitar o filho ao nascer, levantando-o nos braços, ou de rejeitá-lo, deixando-o no chão e o abandonando. Mais uma vez a rejeição não era uma particularidade dos pobres. Entre os ricos ela era motivada pela ganância na divisão dos bens e o objetivo era reduzir o número de herdeiros.

Na Idade Média, o índice de mortalidade infantil preocupava os líderes governamentais, devido à necessidade de defesa dos países e de mão-de-obra. Somente cerca de $20 \%$ das crianças sobreviviam e, entre as abandonadas, apenas $10 \%$ chegavam aos vinte anos. Diante da situação, uma das medidas implementadas foi a de recompensar as famílias que adotassem crianças abandonadas.

Apenas em fins do século XIII, a criança adquiriu o valor de um produto em extinção.

No Brasil, no periodo da colonização, as mulheres que aqui chegavam representavam força de trabalho e objeto de prazer dos senhores brancos. Conseqüentemente, os primeiros brasileiros foram fruto desses relacionamentos marcados pela violência, pelo estupro, e não por histórias de amor.

Além disso, os colonizadores trouxeram consigo doenças estranhas aos nativos, o que fez crescer a mortalidade geral, tornando muitas crianças órfãs.

Como uma das primeiras manifestações de valorização da criança, em 1738, a Capitania do Rio de Janeiro criou o primeiro asilo para crianças no país (SOUZA NETO 2000; SANTANA 2000), o que representava uma medida de proteção, como nos tempos de hoje representam as entidades de abrigo, muito embora, os atuais motivos de encaminhamento para instituições não tenham a orfandade como razão principal. 
A primeira significante norma em defesa dos direitos da criança foi a Lei do Ventre Livre, de 28 de setembro de 1871, que tornou libertos os filhos das escravas. Mas, embora procurasse defender os direitos da criança negra, trouxe outras formas de prejuízo, ressaltando-se a vida em condições de pobreza (SOUZA NETO 2000; SANTANA 2000).

Durante três séculos e meio, as iniciativas em relação às crianças, no Brasil, foram quase que totalmente de caráter religioso. Nas ações implementadas, constava a criação de casas para alojar as crianças (SOUZA NETO 2000; SANTANA 2000).

A única instituição de assistência social colonial, além das ajudas de cunho religioso, era a esmola. Havia o pressuposto de salvação por meio dessa prática, além de ser uma forma de ocultar a desigualdade social e econômica (SOUZA NETO 2000).

A partir do século XVIII, chamava a atenção o número de crianças deixadas nas ruas pelas mães, durante a noite, sendo, muitas vezes, devoradas por animais ou vítimas das intempéries ou da fome (SOUZA NETO 2000; MARCILIO 2001; ROQUE e FERRIANI 2002).

Entre as causas de abandono estavam a ocultação de adultério, a pobreza, a morte ou doença dos genitores e a saída do pai de casa (SOUZA NETO 2000; MARCILIO 2001).

Para amenizar a situação dos enjeitados, em 1726, na Bahia, foi instituída a denominada "roda dos expostos". "Consistia de um equipamento que girava através de uma parede onde se colocava a criança enjeitada ou exposta, que era recebida por alguém do outro lado, sem que se pudesse ver quem colocava nem quem a recebia" (SANTANA 2000, p.21), garantindo-se, assim, o anonimato do expositor e evitandose o aborto e o infanticídio (MARCILIO 2001; ROQUE e FERRIANI 2002). 
Durante o século XVIII, foram implantadas mais duas rodas dos expostos: uma no Rio de Janeiro, em 1738, e outra em Recife, em 1789. No início do Império foi instalada a roda de São Paulo (1825). Durante o século XIX foram implantadas mais nove rodas (MARCILIO 2001).

Antes da existência da roda, as crianças abandonadas deveriam ser assistidas pelas Câmaras Municipais, que alegavam falta de recursos para assumi-las. A maioria dos bebês abandonados acabava sendo acolhida por familias substitutas, como "filhos de criação", tanto por espírito de caridade, como, em muitos casos, para utilizá-los, quando maiores, como mão-de-obra fiel e gratuita, sem direito à herança (SOUZA NETO 2000; MARCILIO 2001).

$O$ alto índice de mortalidade infantil das crianças colocadas no sistema de roda chegou a $70 \%$ e preocupou os médicos higienistas da época, levando-os a sugerirem o redimensionamento das ações e a desestimular a alternativa de assistência da Casa dos Expostos (SANTANA 2000; MARCILIO 2001).

O movimento teve a adesão de juristas, que passaram a pensar em novas leis para proteger a criança abandonada e para corrigir uma incômoda questão social, que era a adolescência infratora (MARCILIO 2001).

Apesar do movimento contra a roda dos expostos, as mais importantes sobreviveram até o século XX (MARCILIO 2001).

O sistema de roda, apesar de deficitário, foi importante na história da construção de políticas públicas de atenção à criança desvalida, pois a partir dele observou-se a participação da opinião pública, de profissionais de saúde e a reflexão sobre alternativas de atendimento à criança (SANTANA 2000).

Da metade do século XVIII ao início do século XIX, os discursos de médicos e políticos incentivavam as famílias a responsabilizarem-se pela criação dos filhos (SANTANA 2000). 
Em 1762, com a publicação de Émile, Rousseau disseminou uma nova concepção de família, embasada no novo conceito de amor materno (SANTANA 2000), pois até então a família cumpria as funções de assegurar a transmissão da vida, dos bens e do nome, sem penetrar no campo da sensibilidade (ARIÈS 1981).

No final do século XIX, a culpa pelo abandono e falta de proteção da criança era lançada sobre as famílias. Na primeira metade do século $\mathrm{XX}$, as condições econômicas e a desagregação familiar eram apontadas como as principais causas de abandono (SOUZA NETO 2000; SANTANA 2000; ROQUE e FERRIANI 2002).

Como tentativa de mudar o modelo vigente na época, em 1921 o governo criou o "Serviço de assistência e proteção à infância abandonada e ao delinqüente". Em 1927, foi aprovado o Código de Menores, que demonstrava avanço ao prever a vigilância à saúde e de valorizar, pelo menos teoricamente, a formação educacional da criança e do adolescente (menor) (SANTANA 2000; ROQUE e FERRIANI 2002).

A partir de 1930 foram criadas associações filantrópicas para assistir a infância desamparada, fundamentadas na ciência para substituir o modelo da caridade, mas sem abandonar inteiramente os preceitos religiosos. $\grave{A}$ filantropia coube organizar a assistência dentro de novas exigências sociais, políticas, econômicas e morais (MARCILIO 2001).

Na década de 1940, o Departamento Nacional da Criança normatizou o funcionamento e a qualidade do atendimento em creches (SOUZA NETO 2000).

Em 1941, no governo Getúlio Vargas, foi implantado o Serviço de Assistência a Menores (SAM), cuja função era organizar os serviços de assistência. O Serviço foi marcado pela corrupção e maus tratos aos meninos (SANTANA 2000). 
Em 1964, em substituição ao SAM, o governo militar instituiu a Fundação Nacional do Bem-Estar do Menor (FUNABEM), com o objetivo de implantar a política nacional do bem-estar do menor. A FUNABEM era representada nos estados pela Fundação do Bem-Estar do Menor (FEBEM). Como a FUNABEM tão somente reproduziu o modelo carcerário-punitivo prejudicial ao desenvolvimento das crianças e adolescentes, foi extinta em 1990 (SOUZA NETO 2000; SANTANA 2000).

Na década de 1970, surgiram as Organizações Não Governamentais (ONGs), instituições sem fins lucrativos, que funcionam sem articulação com a política de ação social do governo e que tentam preencher parte da lacuna deixada por esta. Muitas ONGs dedicam-se à melhoria das condições de vida de crianças e oferecem serviços como creches, abrigos, entre outros (SANTANA 2000). E essa é a realidade no município de Vitória-ES, pois todas as entidades de abrigo são mantidas por Organizações Não Governamentais.

Em 1979, foi aprovado o novo Código de Menores, que tratava a criança como sujeito de direito e da humanização da atenção dirigida a ela. A inovação foi a eliminação da denominação "menor abandonado e delinqüente" (SANTANA 2000; ROQUE e FERRIANI 2002).

Em 1982, surgiu a Pastoral da Criança, cujo trabalho busca a construção de uma cultura centrada no respeito e na valorização da vida (SANTANA 2000), princípios estes essenciais em ações na área social.

No ano de 1985, teve início o Movimento Nacional de Meninos e Meninas de Rua (MNMMR), que via a criança e o adolescente como sujeitos de direitos, que deviam participar da construção da sociedade e de suas vidas (SANTANA 2000).

O MNMMR é uma Organização Não Governamental, composta por uma rede de educadores e voluntários, que tem por objetivo a defesa dos direitos da infância e da adolescência. É um movimento de natureza política, social e cultural (MNMMR 2004). 
Promulgada em 05 de outubro de 1988, a Constituição Federal assegura direitos às crianças e adolescentes. Em seu Artigo 227, estabelece:

É dever da família, da sociedade e do Estado assegurar à criança e ao adolescente, com absoluta prioridade, $o$ direito à vida, à saúde, à alimentação, à educação, ao lazer, à profissionalização, à cultura, à dignidade, ao respeito, à liberdade e à convivência familiar e comunitária, além de colocá-los a salvo de toda forma de negligência, discriminação, exploração, violência, crueldade e opressão.

No Parágrafo $1^{\circ}$, o mesmo Artigo diz, ainda, que "o Estado promoverá programas de assistência integral à saúde da criança e do adolescente, admitida a participação de entidades não governamentais ..."

Em relação à responsabilidade dos pais, a Constituição determina, em seu Parágrafo 229, que "os pais têm o dever de assistir, criar e educar os filhos menores..."

Segundo MARCILIO (2001), a Constituição de 1988 inseriu na sociedade brasileira os Direitos Internacionais da Criança, proclamados pela ONU na década de 1950.

Mais precisamente, a Declaração Universal dos Direitos da Criança (Anexo 1) foi proclamada no dia 02 de novembro de 1959 , e aborda a situação da criança abandonada em dois de seus princípios. 


\section{O Princípio VI prega que:}

A criança necessita de amor e compreensão, para o desenvolvimento pleno e harmonioso de sua personalidade; sempre que possível, deverá crescer com o amparo e sob a responsabilidade de seus pais, mas, em qualquer caso, em um ambiente de afeto e segurança moral e material; salvo circunstâncias excepcionais, não se deverá separar a criança de tenra idade de sua mãe...

Em continuidade, delega à sociedade e às autoridades públicas a obrigação de cuidar do então denominado menor abandonado.

Em seu Princípio IX declara que "a criança deve ser protegida contra toda forma de abandono, crueldade e exploração ..."

Para tratar mais especificamente sobre as questões relativas às crianças $\mathrm{e}$ adolescentes, em 13 de julho de 1990 , foi sancionada a Lei $n^{\circ} 8.069$, que dispõe sobre o Estatuto da Criança e do Adolescente (ECA).

O ECA constituiu-se em um marco no redirecionamento da atenção à infância e adolescência no país e no reconhecimento do direito à cidadania, independentemente da classe social de origem (PINO 1990; SANTANA 2000; MARCILIO 2001; ROQUE e FERRIANI 2002).

O ECA garante à criança e ao adolescente o direito à vida e à saúde, o direito à liberdade, ao respeito e à dignidade, o direito à convivência familiar e comunitária.

Em relação ao direito à convivência familiar, o Artigo 19 diz que "toda criança ou adolescente tem direito a ser criado e educado no seio da sua família e, excepcionalmente, em família substituta ..." 
Entre outras condições, nos casos de falta, omissão ou abuso dos pais ou responsáveis são aplicáveis medidas de proteção à criança e ao adolescente, como prega o Artigo 98.

Uma das medidas de proteção citadas no Artigo 101 é o abrigo em entidade.

Consta ainda do Artigo 101, em seu Parágrafo único, que “o abrigo é medida provisória e excepcional, utilizável como forma de transição para a colocação em familia substituta, não implicando privação de liberdade.“

O Artigo 92 do Estatuto prevê o seguinte:

As entidades que desenvolvam programas de abrigo deverão adotar os seguintes princípios:

I - preservação dos vínculos familiares;

II - integração em família substituta, quando esgotados os recursos de manutenção na família de origem;

III - atendimento personalizado e em pequenos grupos;

IV - desenvolvimento de atividades em regime de coeducação;

V - não desmembramento de grupos de irmãos;

VI - evitar, sempre que possível, a transferência para outras entidades de crianças e adolescentes abrigados;

VII - participação na vida da comunidade local;

VIII - preparação gradativa para o desligamento;

IX - participação de pessoas da comunidade no processo educativo.

O Artigo 93 diz que "as entidades que mantenham programas de abrigo poderão, em caráter excepcional e de urgência, abrigar crianças e adolescentes sem 
prévia determinação da autoridade competente, fazendo comunicação do fato até o $2^{\circ}$ dia útil imediato."

Os instrumentos de operacionalização do Estatuto são os Conselhos Municipais de Direitos da Criança e os Conselhos Tutelares, nos quais a sociedade civil organizada passa a desempenhar importante papel na deliberação e controle das ações relativas aos direitos da criança e do adolescente e no atendimento direto a eles (PINO 1990; SANTANA 2000; MARCILIO 2001; ROQUE e FERRIANI 2002), o que caracteriza o avanço da legislação, embora, na prática, discuta-se a preparação dessas pessoas para a tomada de decisões e a habilidade na condução dos fatos.

Mais recentemente, em 07 de dezembro de 1993, foi sancionada a Lei $n^{\circ}$ 6.742 - Lei Orgânica da Assistência Social (LOAS), que em seu Artigo $2^{\circ}$ inclui entre os objetivos da assistência social a proteção à família, à infância e à adolescência, e o amparo às crianças e adolescentes carentes.

Apesar da existência de leis que garantem os direitos da população infantojuvenil, "a crise econômica, política e social sofrida pela sociedade brasileira vem aumentando seu empobrecimento, agravando a exclusão social e privando de direitos fundamentais uma parcela cada vez maior da população." (SILVA e col. 2001).

A partir dessa constatação, deve-se ressaltar o objetivo da LOAS que diz respeito à proteção à família, pois não há como direcionar o olhar somente para as crianças e adolescentes e se esquecer de que eles estão inseridos em um contexto familiar e social, que servirá de referencial ao longo de suas vidas.

Segundo SANTANA (2000, p.34), "para que esses direitos possam ser assegurados efetivamente, faz-se necessária uma mudança do próprio sistema vigente, uma reorganização social e econômica, através de uma prática política mais justa, em que a vida seja valorizada e o bem-estar de toda a população se torne uma prioridade." 
Considera-se que cabe, também, à sociedade em geral, compartilhar responsabilidades e cumprir, cada um, a parte lhe couber, no sentido de garantir uma vida digna para todos.

MELLO (1999) acrescenta a importância do aspecto educacional e propõe linhas de ação com a intenção de transformar a universidade em um foro de discussão e de transformação da lei em um instrumento de promoção de direitos. São elas:

- ensinar responsabilidade junto com as técnicas;

- envolver os alunos em trabalhos de extensão;

- romper as barreiras que separam as especialidades;

- incluir no currículo noções básicas de direitos humanos;

- incentivar a criatividade dos alunos e desenvolver neles a humildade necessária ao exercício profissional;

- transformar a ética em um princípio ativo;

- enfim, fornecer consciência e conhecimento.

Ao proporcionar uma sólida formação técnica e humanística aos profissionais, as universidades estarão dando uma boa contribuição à sociedade. Mas a contribuição no campo da educação, não deve restringir-se ao nível superior, devendo ocorrer, também, nos níveis de educação básica e educação profissional.

A colaboração pode ser, ainda, ampliada, por meio do estabelecimento de parcerias e pela execução de projetos, como o exemplo que segue:

No espaço antes ocupado pela extinta FEBEM de Minas Gerais, em Belo Horizonte, teve início um projeto de atendimento a crianças e adolescentes portadores de necessidades especiais e crianças e adolescentes em situação de risco pessoal ou social. $\mathrm{Na}$ área existem oito casas do Programa Casas Lares e uma casa do Programa Casa de Passagem. O projeto conta com a parceria do Governo Estadual, da Prefeitura, da Polícia Militar, da APAE, do SESC e de uma Fundação ligada aos três principais clubes mineiros de futebol (FAAC), cada qual com o seu papel e a sua 
responsabilidade definida. Duas escolas, uma estadual e uma municipal, recebem os alunos portadores de necessidades especiais e, em contrapartida, os alunos que necessitam de reforço escolar contam com o Apoio Pedagógico do Projeto. Há uma equipe com profissionais da área social, de saúde e de educação. São realizadas atividades educacionais, culturais, esportivas e de lazer, além de festas que estreitam os laços com a comunidade e faz com que, a população, também, se aproprie do espaço, o que contribui para a inclusão social dos educandos (ESCOLA DE ADMINISTRAÇÃO DE EMPRESAS DE SÃO PAULO 2000).

O exemplo ilustra bem os temas abordados neste capítulo, pois a medida aproveitou o espaço, antes ocupado para a execução de uma política pouco ou nada resolutiva, para a implantação de um projeto amplo e moderno, pautado em parceria, e que tem como propósito garantir benefícios a crianças e adolescentes, de acordo com o previsto na legislação em vigor.

A contextualização histórica e referente a aspectos legais, teve como objetivo situar no tempo a origem de problemas, como o abandono, a adoção, as casas de proteção (entidades de abrigo), a violência sexual, as desigualdades sociais e econômicas, a justificativa do poder público sobre a falta de recursos, o surgimento das ONGs e a dificuldade de cumprimento das previsões das leis. Problemas que, entre outros, ainda se fazem presentes nas famílias e na sociedade do século XXI e que se constituem em grandes desafios.

\subsection{Família e violência familiar}

A importância depositada na família pode ser percebida ao se atribuir a ela a principal responsabilidade por apresentar o mundo social à criança e por contribuir para a sua formação. É por meio dos padrões culturais oferecidos, ou seja, valores, sentimentos e idéias que o indivíduo aprenderá a se comportar socialmente e também incorporará hábitos, modos de vida e maneiras de reagir afetivamente. Em suma, os pais funcionam como modelos e os padrões de comportamento oferecidos orientarão 
o indivíduo diante da vida (DIAS 1992; MENEZES 1995; VIVES 1995; MAURO 1998; WAGNER e COL 1998).

$\mathrm{Na}$ relação entre pais e filhos deve haver espaço para se conversar de forma amigável, fundamentada e sincera, pois o desenvolvimento de conceitos e valores relacionados à honestidade, lealdade, cooperação, respeito ao outro e a si mesmo, entre outros, seguramente minimizarão a chance de surgirem problemas futuros (ZAGURY 1996). E esses conceitos e valores são fortemente influenciados pela familia.

Nesse caso, é importante definir o que se entende como família, embora existam distintas maneiras de se compreender a sua constituição. Para Mauro (1998), a definição de família pode ser segundo a sua amplitude: família nuclear, composta por pai, mãe e filhos; pode ser família ampliada por consangüinidade; família ampliada por laços matrimoniais; ou ainda, família acrescida de conhecido e pessoa da localidade. Já no Estatuto da Criança e do Adolescente (Artigo 25), a família natural é definida como a comunidade formada pelos pais ou qualquer deles e seus descendentes.

Neste trabalho, considera-se como familia, tanto o grupo formado pelo pai, mãe (ou um deles) e filho(s), como também aquele em que há um outro responsável pela(s) criança(s) ou adolescente(s), que assuma o papel dos pais, tanto em relação aos cuidados, educação e formação, como também na ligação afetiva.

Apesar de haver muitas diferenças entre as famílias, a instituição família, por sua força estrutural e pelos laços sentimentais, prepondera na educação dos filhos. $O$ padrão de relacionamento estabelecido entre a criança e seus pais, a experiência de amor e carinho, ou a falta deles, influencia e modela a forma como a criança se relacionará com os outros quando adulto, e influencia a sua auto-estima e a sua saúde mental (CARIOLA e JAEHN 1985; DIAS 1992; MENEZES 1995; MONTEIRO e col. 1995; SILVA e col. 2001). 
Além da importante função da família de proporcionar a satisfação das necessidades de amor entre seus componentes, há outras necessidades específicas de cada fase. $\mathrm{Na}$ infância, a responsabilidade familiar é principalmente a de nutrição, proteção e socialização, enquanto que na adolescência, há maior necessidade de apoio e orientação do que dos cuidados anteriormente citados, por caracterizar-se como uma fase de importantes mudanças preparatórias para a vida adulta (MAURO 1998; ARPINI 1999; DE ANTONI e KOLLER 2000).

No caso de crianças e adolescentes institucionalizados, esse papel é transferido para os profissionais que lá atuam, principalmente, para os educadores, por terem contato mais direto com as crianças e adolescentes, embora se entenda que, no espaço institucional, todos possuam responsabilidade de educar.

Ao educar, é necessário dar liberdade com limites, cuidar, observar, prover contato afetivo permanente, dialogar, ensinar o bom senso e o respeito ao próximo, seguir passo a passo a evolução das necessidades e das modificações da criança e do adolescente (MAIA 1998; WAGNER e col. 1998).

Dessa forma, educar não é um processo simples, uma vez que exige dedicação, carinho, determinação, compreensão, paciência, equilíbrio. Torna-se, ainda, tarefa mais complexa, quando delegada a uma pessoa que não pertença à família, como nos ambientes institucionais.

Porém as dificuldades não acontecem somente no ambiente externo. Também, dentro do contexto familiar, existem situações em que a família não assume as suas responsabilidades e rejeita a criança. A rejeição pode ser por um dos pais ou por ambos. Para NERY $(1998$, p.30), a receptividade a uma criança "está condicionada ao grau de consciência, ao nível de educação, às condições financeiras e à cultura familiar dos pais futuros".

Em outros casos, o fato de não dispor de recursos para satisfazer as necessidades básicas da família gera conflitos no ambiente familiar, que acabam 
também por expor a criança (DIAS 1998; PAPALIA e OLDS 1998). Nessa situação, a criança pode se tornar vítima da negligência, da violência e, também, do abandono.

Uma boa relação familiar é fundamental e insubstituível na promoção do desenvolvimento saudável do indivíduo, principalmente pelo atendimento das suas necessidades afetivas. No entanto, o inverso pode ocorrer se essa relação for marcada por experiências negativas, como a violência familiar.

A violência familiar é aquela que acontece dentro do lar e cujas raizes estão associadas ao contexto histórico, social, cultural e político em que se insere. Apesar de estar intimamente relacionada à posição de poder do adulto frente à criança, não pode ser compreendida somente como uma questão decorrente de conflitos entre pais e filhos. A violência familiar pode ocorrer na forma de violência física, sexual, psicológica, de negligência e de abandono (DE ANTONI e KELLER 2000; SILVA e col. 2001; ROQUE e FERRIANI 2002).

De acordo com SILVA e col. (2001), a violência física corresponde ao uso de força física no relacionamento com a criança ou adolescente. A violência sexual está relacionada ao ato ou jogo hetero ou homossexual entre um adulto e uma criança ou adolescente. A violência psicológica consiste em uma ação negativa do adulto sobre a criança como, por exemplo, rejeitar, isolar ou aterrorizar. A negligência é a omissão da família em suprir as necessidades físicas e emocionais de uma criança ou adolescente, excetuando as situações originárias da carência de recursos sócioeconômicos.

Para PAPALIA e OLDS (1998), os índices de violência física e psicológica são similares para meninos e meninas, mas é quatro vezes mais provável que as meninas sejam vítimas de abuso sexual. A negligência ocorre mais comumente, acontecendo em $70 \%$ dos casos em que as vítimas são os adolescentes.

CARVALHO (2002) relata dados de uma pesquisa realizada pelo Conselho Tutelar de Niterói - RJ, sobre a prevalência de maus tratos em crianças e 
adolescentes. Foram analisados 2.035 prontuários, dos quais $56,0 \%$ relataram casos de maus tratos, sendo que $\mathbf{8 4 , 5 \%}$ dos mesmos ocorreram na própria casa das crianças e adolescentes, e, em $50,0 \%$ dos casos, os agressores eram os pais. A violência física e o abuso sexual foram os mais comuns, com incidências de $82,9 \%$ e $17,0 \%$, respectivamente. Segundo os resultados da pesquisa, $62,5 \%$ das ocorrências aconteceram mais de três vezes com a mesma vítima, significando a reincidência do fato.

DE ANTONI e KOLLER (2000) obtiveram resultados semelhantes em um estudo realizado em Porto Alegre, em que $80 \%$ dos casos de violência denunciados ocorreram na casa da vítima, sendo os pais biológicos ou adotivos os responsáveis pela agressão, na maioria dos casos. Os números em relação aos casos de abuso sexual chamam ainda mais a atenção, pois em $90 \%$ das ocorrências o agressor ocupava a função paterna.

Segundo essas autoras, a violência familiar e os maus-tratos ocorrem em todas as classes sociais, sendo que nas classes média e alta, os eventos são "abafados" e resolvidos pelos familiares, não tendo o mesmo desfecho que nas classes menos favorecidas. Por outro lado, há autores, como PAPALIA e OLDS (1998), que afirmam que a renda familiar tem relação inversa à negligência e ao abuso sexual, físico e psicológico, ou seja, nas classes mais baixas é mais freqüente do que nas classes altas.

Em relação ao comportamento, as crianças violentadas choram mais, recusam o contato físico e, freqüentemente, apresentam atraso na fala. Podem se tornar mais retraídas ou agressivas, ter falta ou excesso de apetite, insônia ou muito sono, enurese noturna e recusa de freqüentar a escola. Quando adultas tendem a ser medrosas, ansiosas, deprimidas, irritadas ou agressivas. As vítimas de abuso sexual parecem ter uma necessidade de afeição maior que a média, o que as torna mais susceptiveis aos molestadores. As meninas violentadas sexualmente tornam-se preocupadas com sexo em uma proporção maior que as não violentadas (PAPALIA e OLDS 1998; CARVALHO 2002). 
MONTEIRO e col. (1995) e DIAS (1998) consideram que a experiência de violência na infância pode repercutir na vida adulta, prejudicando o desenvolvimento intelectual e o relacionamento social.

Seguindo a mesma linha, KLAUS e col. (2000) afirmam que as experiências da infância afetam a forma como o indivíduo age na sua maternidade ou paternidade.

Em consonância, CÉLIA (1998) relata que quem foi vítima de abusos, maus tratos e negligência poderá repetir o mesmo com seus filhos, o que é reforçado por PAPALIA e OLDS (1998), pois quem foi privado de bons pais, algumas vezes não sabe como ser bom pai ou mãe para seus filhos.

MONTEIRO e col. (1995) verificaram, em estudo realizado em Campinas $\mathrm{SP}$, que $63,3 \%$ dos pais que agrediram fisicamente seus filhos foram vítimas de violência na infầncia.

Mas o fato de uma criança ter sofrido violência não a leva inevitavelmente a se tornar agressora, quando adulta. Dois terços de crianças vítimas de violência tornam-se bons pais ao crescerem (PAPALIA e OLDS 1998).

Por esse motivo, CÉLIA (1998) ressalta a importância de realizar um trabalho junto às gestantes, procurando conhecer dados sobre a sua infância. E o mesmo deveria ser feito junto aos pais, sempre que possível.

Algumas crianças têm a capacidade de se recuperar (superar) de situações negativas, que afetariam o desenvolvimento emocional da maioria das crianças, mantendo-se criativas, independentes e com consciência do seu próprio valor; são as chamadas, por diversos autores, de crianças resilientes (ALVAREZ e col. 1998; PAPALIA e OLDS 1998; DE ANTONI e KELLER 2000). Mas, para JUNQUEIRA e DELANDES (2003), não se é resiliente para toda e qualquer situação e nem a todo o momento. A resiliência não é um processo estanque, uma vez que o indivíduo pode 
se apresentar resiliente diante de uma situação, mas não frente à outra. Assim, sugerem que o ideal seria falar da capacidade do indivíduo de, em determinados momentos e circunstâncias, lidar com a adversidade (SANTOS e BASTOS 2002).

Em estudo realizado por ALVAREZ e col. (1998), sujeitos considerados resilientes enfatizaram a importância da maternagem, ou seja, de um apego seguro: irmãos; parentes; outras pessoas; instituição. Foi ressaltada, também, a paternagem exercida pela instituição, entendida como o fator educativo de "mostrar o caminho". Os sujeitos expressaram, ainda, o desejo pelo direito à equidade e não à exclusão, buscando, ativamente, criar sentido para suas próprias vidas.

Na tentativa de definir apego seguro, pode-se dizer que é a confiança no amor de uma pessoa, confiança de ser compreendido e de ter suas necessidades satisfeitas, sentimento do mundo como um local seguro. A satisfação repetida das necessidades físicas e emocionais desenvolve o sentimento de confiança e de competência no indivíduo (KLAUS e col. 2000; CARVALHO 2000).

CARIOLA e JAEHN (1985) relatam que a criança que encontra um bom lar, após o período de privação, começa a perder os sintomas de rejeição, de ansiedade e de apatia adquiridos. $\dot{E}$ por isso que existe a expectativa de que crianças e adolescentes institucionalizados sejam inseridos em lares substitutivos, mas, certamente, desde que o retorno ao lar de origem não seja mais possível, pois, uma vez resolvida a situação que deu origem ao ato da institucionalização, a preferência é a volta à família original.

No entanto, as famílias vítimas da pobreza e da exclusão tendem a manter os seus filhos em uma vida também de exclusão, embora nem sempre aconteça desta forma. Segundo CARVALHO e GUARÁ (1994), no caso de crianças deslocadas de seu contexto familiar, há uma propensão de se culpabilizar a família, apesar de tratarse da mesma família esquecida pelas diferentes políticas sociais ao longo da história. Por este motivo, enfatizam que é necessário superar a visão de que a família é 
incapaz, incompetente, desestruturada ou culpada. Em lugar de tecer críticas, deve-se criar condições para a manutenção da vida em família.

ARPINI (1999) considera como situação de risco a falta de garantias mínimas de proteção, amparo e sobrevivência, que garantam ao indivíduo o direito à cidadania, desde aspectos econômicos até questões sociais e familiares. Assim, há a necessidade do estabelecimento de uma política social que vá além do assistencialismo emergencial, mas que vise eliminar o problema do desemprego, de moradia, saúde e educação, modificando desta forma o quadro social (WEBER 1996b).

WINNICOTT (1999), ao abordar o tema da criança privada da vida familiar, faz recordar que a prioridade de uma comunidade deve ser manter os seus membros saudáveis, e considera que apenas as crianças criadas em seus próprios lares apresentam condutas satisfatórias e compensadoras. Ressalta que a prioridade na atenção deve ser o fornecimento, à família, de condições básicas em termos de moradia, alimentação, vestuário, educação e lazer.

Para que a família tenha condições de se manter e de suprir as necessidades de sua criança e/ou adolescente, é preciso garantir, à mesma, proteção jurídica e econômica, além de apoio psicossocial.

Entretanto, na vida prática, as questões nem sempre são encaminhadas da forma desejável e, ainda hoje, em pleno século XXI, diante de um mundo globalizado e de grandes debates e avanços tecnológicos, não se conseguiu por fim ou reduzir as injustiças e a desigualdade social. E, por conseqüência, crianças e adolescentes continuam sendo encaminhados para entidades de abrigo. 


\subsection{Institucionalização de crianças e adolescentes}

Segundo dados da FUNABEM, no final da década de 1970, havia no Brasil 15 milhões de crianças e adolescentes abandonados, o que representava mais de $10 \%$ da população brasileira (DIAS 1992).

Em termos numéricos, a situação da institucionalização apresentou avanços, mas, em relação aos aspectos operacionais, ainda, encontra-se semelhança com o passado.

Como exemplo, pode-se citar os questionamentos de KOSMINSKI (1993), que se mantêm muito atuais, ao analisar a situação das crianças internas em uma Unidade Educacional da FEBEM/SP:

- Se, na infância, as relações sociais são geradas a partir de vínculos afetivos, que relações as crianças podem estabelecer em uma situação de submissão, mediada pela burocracia?

- Ao suprir a carência material das crianças, estar-se-ia criando um novo tipo de sociabilidade, pobre em afetividade?

- Como enfrentar a dupla exclusão: da família e da sociedade?

O autor diz, ainda, que em uma situação de institucionalização, “... as necessidades da criança encontram-se submetidas ao controle dos funcionários, sendo todas elas tratadas da mesma forma e obrigadas a executar as mesmas atividades em conjunto, sob vigilância." (p.158)

As instituições suprimem o senso crítico, a criatividade e a capacidade de iniciativa das crianças, que acabam por fazer o que é determinado e não o que desejam em um determinado momento. Predominam as regras e não as contingências. Tudo é estabelecido previamente e sem a participação dos institucionalizados (GOFFMAN 2001; WEBER 1996b). 
A identidade da criança institucionalizada passa a ser construída a partir de duas forças contraditórias: o processo de padronização imposto pela instituição e a afirmação da sua individualidade, pela busca da resistência, para defender e preservar seus valores, expressa nos pequenos gestos de rebeldia; é uma questão de sobrevivência. A agressividade resulta das condições adversas a que o indivíduo é submetido, pois ambiente e indivíduo influenciam um ao outro, em um processo contínuo de desenvolvimento e de mudança (GOMIDE 1996; SILVA 1997; WENDLAND 2001; SANTOS e BASTOS 2002).

Nesse meio de cobranças e pressões, está em jogo a desestruturação ou não da personalidade do indivíduo, que se dá à medida que ele cede às exigências do meio e incorpora valores que deveria repudiar (SILVA 1997).

Aqui cabe a definição e a reflexão de GOFFMAN (2001) sobre o que é uma instituição total, um híbrido social, que em parte é uma comunidade residencial e em outra é uma organização formal. As instituições totais funcionam como estufas para mudar pessoas, em que cada uma passa a ser um experimento natural sobre o que se pode fazer ao indivíduo.

KOSMINSKI (1993) relata que alguns aspectos chamaram a sua atenção durante a visita realizada à citada Unidade Educacional: as crianças disputavam quem seguraria as mãos dos visitantes, "grudando" neles; havia ausência de desordem, a disciplina se sobrepunha à individualidade; não havia objetos de uso pessoal; as crianças não tinham a posse sequer das roupas que usavam; a falta de atividades aumentava a impressão de abandono.

MARTINS NETO (2001) observou comportamento hostil, agressividade, ansiedade e agitação em crianças institucionalizadas e atribuiu a carência afetiva exagerada ao sentimento de rejeição vivenciado. BORGES (1981) considerou a ambivalência de sentimentos e de atitudes das crianças carentes de afeto. Por um lado elas necessitam de contatos afetivos, por outro receiam ser novamente 
frustradas. A conseqüência é procurarem afeto e carinho, mas também agredirem e serem hostis.

Outros problemas são gerados pelo elevado número de crianças, pelo tratamento massificado, pela rotatividade dos funcionários, pelas transferências de uma instituição para outra, baseadas em critérios independentes da vontade das crianças, entre outros. As transferências impedem a formação de relações sociais duradouras, tanto com os funcionários como com as outras crianças (KOSMINSKI 1993; WEBER 1999).

Para WEBER (1996b, 1999), a impossibilidade de formação e manutenção de vínculos afetivos em uma instituição é a base dos prejuízos no desenvolvimento e na saúde das crianças.

A autora relata que a preocupação com os efeitos prejudiciais da institucionalização é relativamente recente, e as críticas ao sistema como despersonalizante datam do início do século XX, nos Estados Unidos e na Europa. No entanto, apenas na década de 1970, um movimento de desinstitucionalização ganhou volume, enfatizando a necessidade da inserção da criança em uma família e em uma comunidade.

Visando analisar os efeitos da institucionalização ou da vida familiar no sorriso de crianças e adolescentes, por considerá-lo um indicador de felicidade, GOMIDE (1996) realizou um estudo para avaliar a diferença no nível de sorriso de crianças que vivem em uma instituição, em uma favela e em um prédio de classe média.

Os dados indicaram que as crianças da favela que mantêm relações familiares, mesmo sem boas condições materiais, sorriem tanto quanto as crianças de classe média, e os dois grupos sorriem, significativamente, mais que as crianças da instituição. 
A autora considera o resultado como sugestivo de que uma vida social e afetiva satisfatória seria a base para um bom desenvolvimento emocional e para a possibilidade de felicidade.

A história de vida das crianças, anterior à institucionalização, de modo geral é caracterizada por perdas e sofrimentos. Diante de situações como condições precárias de vida, problemas de saúde, violência em família, separação dos pais, entre outras, a alternativa tem sido a institucionalização (KOSMINSKI 1993; WEBER 1996a; WEBER 1996b).

Segundo WEBER (1999), a maioria das crianças chega às instituições por meio de suas próprias famílias, normalmente monoparentais (só a mãe presente). As famílias, que inicialmente pensam em utilizar a instituição como uma situação provisória, desaparecem, mas continuam detentoras do pátrio poder. Nesses casos, a criança não pode ser colocada em uma família substituta. Algumas vezes, não existem documentos sobre as crianças e, muito menos, dados sobre a sua história de vida. Essas situações constituem-se fatores causais de uma permanência mais longa na entidade de abrigo.

Para KOSMINSKI (1993), a institucionalização constitui um ato de violência, pois corresponde à desapropriação da vida anterior à da instituição. O que ocorre é uma brusca ruptura entre passado e presente, somada à incerteza do futuro.

Nos casos de violência familiar, a institucionalização pode ser entendida como mais uma violência ao seu desenvolvimento emocional e psicológico (DE ANTONI e KELLER 2000).

WEBER (1999) considera essencial que a criança, como detentora de direitos, tenha acesso à sua própria história e à sua realidade atual, pois o desconhecimento da sua situação leva a tecer fantasias sobre suas perspectivas futuras. 
A falta de história de vida é uma perda séria para a criança. Sendo assim, é urgente reunir todos os fragmentos de informações sobre a vida da criança até aquele momento. Mesmo que a criança não deseje saber os fatos naquele momento, detalhes poderão ser necessários algum tempo depois (WINNICOTT 1999).

A situação é agravada pelo fato das instituições não se dedicarem à manutenção dos vínculos familiares e à realização de um trabalho no sentido de tentar retornar as crianças e os adolescentes às suas famílias de origem (WEBER 1995).

CARIOLA e JAEHN (1985) citam um trabalho que comparou o desenvolvimento de crianças que viveram em instituição até três anos, com crianças colocadas em lares substitutos antes de um ano de idade. As crianças do primeiro grupo, quando tinham de 10 a 14 anos de idade, apresentavam deficiências na função intelectual e no desenvolvimento da linguagem, reduzida concentração, eram socialmente imaturas, insaciáveis de afeto e sem capacidade de formar vínculo. Por isso, o retorno à família de origem ou a inserção em família substituta deve ocorrer no menor prazo possível, prevenindo-se, assim, problemas de saúde e de inserção social.

Utilizando o mesmo método do referido trabalho, no estudo realizado pelas autoras em instituições de quatro cidades do estado de São Paulo, as crianças não apresentaram alterações intelectuais e afetivas. Tal fato foi atribuído à valorização do desenvolvimento físico e emocional das crianças observadas nas instituições que participaram do estudo, à assistência realizada por profissionais das Faculdades de Medicina e Psicologia da região, tanto no aspecto orgânico como psicossocial, e ao fato de as crianças terem sido institucionalizadas com mais de um ano de idade, tendo passado o primeiro ano de vida em companhia da própria mãe ou da mãe substituta. $O$ resultado alcançado demonstra a importância do estabelecimento de uma rede de apoio, com o objetivo de minimizar os prejuizos decorrentes da institucionalização. 
Os dois estudos destacam a influência do convívio familiar durante o primeiro ano de vida.

Uma forma de proporcionar o direito de convivência familiar e comunitária àqueles que não têm mais a possibilidade de voltar ao convívio de sua família de origem é a adoção. Porém, segundo DIAS (1992) e WEBER (1995), apesar de existirem centenas de pessoas desejando adotar uma criança e milhares de crianças desejando uma família substituta, há um forte fator que interfere no encontro das duas partes: o preconceito existente na sociedade, seja ele consciente ou não. WEBER (1995) cita que o sentido moderno de adoção implica em adoções tardias, ou seja, de crianças mais velhas; em adoções morais, de crianças com necessidades especiais ou com graves problemas de saúde; e em adoções inter-raciais. Apesar da relevância do tema, a adoção não constitui foco deste trabalho.

Em atenção aos princípios do Estatuto da Criança e do Adolescente, as entidades de abrigo têm o dever de criar condições para que os vínculos familiares sejam preservados, e nos casos em que não há a possibilidade de retorno à família de origem, devem buscar a inserção da criança ou adolescente em uma família substituta. No entanto, para que os profissionais das entidades tenham a consciência de que, mais do que um compromisso jurídico, existe um compromisso social, e que, além do discurso, deve haver uma prática direcionada a possibilitar à criança ou adolescente o convívio familiar, por todos os beneficios que esse convívio proporciona, é necessário que tenham conhecimento suficiente para mensurar a importância de suas ações na vida dessa clientela.

A outra face da institucionalização, é que, para as crianças e adolescentes, a instituição pode significar o primeiro espaço social que lhes ofereça a oportunidade de resignificar suas trajetórias de vida, estruturando suas rotinas e oferecendo-lhes novos modelos de socialização. Nesse espaço, o educador assume a figura central na rotina dos institucionalizados, por ser quem responde a suas demandas de cuidado e de afeto. A instituição se reveste, então, de uma natureza quase substituta à familia e 
a casa, o que faz aumentar a responsabilidade dos profissionais (SANTOS e BASTOS 2002; MEDEIROS e col. 2002).

$\mathrm{O}$ abrigo deve ser um espaço em que as crianças e adolescentes possam fazer a travessia de uma realidade de mal-estar para outra de bem-estar social. Porém, as práticas assistenciais podem ser avaliadas como sendo um bem e um mal simultaneamente, dependendo da forma como cada usuário delas se apropria para solucionar suas necessidades (SOUZA NETO 2002).

No caso, o chamado usuário, ainda, encontra-se na infância ou adolescência, e, mesmo que já tenha idade para compreender a situação, de acordo com a sua história de vida, seu modo de ser e dos instrumentos que tem capacidade para fazer uso, poderá ter ou não condições para atravessar a realidade social. Nessa circunstância, cabe aos adultos responsáveis pelo mesmo, conduzi-lo ou auxiliá-lo a percorrer o trajeto, em segurança. Mas, para que isso seja possível e aconteça de modo eficiente, os trabalhadores do abrigo necessitam adotar uma profissional, ou seja, devem possuir uma bagagem além da experiência de vida, precisam de conhecimentos específicos na área psicossocial e educacional. Diante de tão grande responsabilidade, a formação de recursos humanos para atuarem junto às crianças $e$ adolescentes em entidades de abrigo se faz necessária.

\subsection{Trabalhadores das entidades de abrigo e formação de educadores}

A dinâmica de trabalho em entidades de abrigo, pela própria natureza das atividades e pela complexidade dos fatos, constitui-se em uma tarefa árdua e exige que seus executores estejam preparados para enfrentá-la, certamente, com o apoio de uma equipe multiprofissional, envolvida e competente, para que os objetivos sejam alcançados de forma satisfatória.

No entanto, durante um trabalho realizado na FEBEM/SP, em 1984, DIAS (1992) observou a existência de um número inadequado de atendentes, ou seja, pessoas responsáveis pelos cuidados diários com as crianças. A relação era de um 
atendente para cada quinze crianças, na faixa etária de, aproximadamente, 5 a 11 anos. Esta relação inadequada gerava uma demanda de cuidados básicos para os monitores e técnicos, prejudicando as suas atuações específicas.

Situação semelhante foi observada por WEBER (1996a), em pesquisa realizada no Paraná. Havia reduzido número de funcionários para lidar diretamente com as crianças e faltavam técnicos especializados.

WINNICOTT (1999) considera que o número limitado de pessoas disponíveis para o cuidado com as crianças pode ser consideravelmente aumentado, se houver a utilização de pessoas "intermediárias" que, por um lado, lidem com as autoridades superiores e, por outro, mantenham contato com as pessoas que executam o trabalho junto às crianças, reconhecendo os seus pontos positivos e os seus êxitos, possibilitando que o processo educativo aconteça e que seja uma tarefa interessante, debatendo as razões dos fracassos e estando acessíveis para proporcionar alívio, quando necessário. A assistência à criança é um trabalho de tempo integral e deixa a pessoa com poucas reservas emocionais para enfrentar as tarefas administrativas. Inversamente, a pessoa capaz de lidar com as questões administrativas, dificilmente, será eficaz no cuidado com as crianças.

Além da questão do número insuficiente de trabalhadores, ANAF e PAIVA (2000) entendem que a instituição guarda, em si, e nos indivíduos que a compõem, uma série de conflitos, quer sejam de ordem individual, interpessoal, intergrupal ou hierárquico.

Exemplificando o exposto, as autoras relatam que, no trabalho que realizaram em uma entidade de abrigo, observaram que não havia uma definição clara do papel dos funcionários e que o fato de as educadoras residirem no local de trabalho, afastava-as do convívio social. Observaram, ainda, que esse isolamento era uma forma de encobrir frustrações de ordem afetiva, havendo, algumas vezes, o rompimento com a vida sexual. 
Diante da situação percebida, as autoras indicaram a necessidade de reflexão sobre os seguintes aspectos: uma educadora sem a sua individualidade bem definida não teria como passar esta noção às crianças; as educadoras, não enfrentando as suas perdas, não teriam como trabalhar as histórias de perdas das crianças; negando a sua sexualidade, não saberiam como agir diante da emergente sexualidade das crianças institucionalizadas.

O exemplo torna-se oportuno, na medida que faz refletir que os conflitos pessoais e grupais não podem chegar a interferir negativamente na vida das crianças e adolescentes, o que gera a necessidade de haver espaço no grupo para se debater o tema e buscar alternativas de ajuda, tanto do sentido de prevenir, como de trabalhar os possiveis conflitos existentes.

Quanto à dinâmica de atendimento, BAZON e BIASOLI-ALVES (2000b) destacam aspectos que educadores e trabalhadores sociais buscaram romper, com a operacionalização de princípios educativos, em alguns serviços de atenção a crianças e adolescentes. Eram eles:

- distanciamento dos técnicos da realidade cotidiana da instituição;

- ausência de metas a serem alcançadas;

- confusão metodológica e falta de embasamento dos trabalhadores;

- ausência de atividades programadas;

- superficialidade das poucas atividades propostas;

- falta de percepção da dimensão educativa inerente às atividades de rotina;

- ênfase em atividades de profissionalização, sem conexão com as potencialidades da clientela e com o mercado de trabalho;

- constante atribuição do fracasso institucional à falta de recursos materiais e às dificuldades da clientela.

Para se garantir um atendimento de qualidade às crianças e adolescentes, era necessário rever as antigas práticas e propor programas que atendessem as necessidades da clientela. 
Os princípios que deveriam ser respeitados para se garantir o enfoque educativo, segundo as autoras acima citadas, eram:

- visão do indivíduo como sujeito;

- expressão do afeto como mediador das relações e como fator essencial à ocorrência da aprendizagem;

- "com-vivência com a criança" por meio de atividades do dia a dia;

- construção de um relacionamento baseado no diálogo e na extinção de mecanismos de dominação;

- participação das crianças, adolescentes e profissionais na elaboração das normas de convivência;

- reconstrução do ambiente, visando uma organização mais justa e igualitária, erradicando as formas de opressão e alienação;

- garantia de acesso a instrumentos necessários para o indivíduo se nortear no mundo e agir sobre ele;

- consideração do profissional "monitor", como peça essencial do processo educacional, tomando a sua formação como condição imprescindível à qualificação do trabalho na área.

Contudo, os esforços não foram suficientes para por fim às práticas assistencialistas e correcionais-repressivas, mas forneceram pistas rumo às mudanças no plano jurídico e operacional.

$\mathrm{Na}$ busca de reversão desse contexto, o Estatuto da Criança e do Adolescente (ECA) e a Lei Orgânica da Assistência Social (LOAS) sugerem práticas de atenção direta, em consonância com princípios educativos de promoção do indivíduo e de seus direitos.

Todavia, ainda se observa uma justaposição das tradicionais práticas assistencialistas, somente com vestígios de caráter social e educacional. Nesse caso, a implantação de um programa de qualificação e de contínua formação dos 
profissionais de entidades de abrigo aparece como um caminho para a melhoria da atenção prestada a crianças e adolescentes e, conseqüentemente, para a educação e a viabilização de oportunidades em suas vidas.

Na falta ou insuficiência de formação específica, o profissional da área de atenção psicossocial tende a reproduzir os moldes da educação recebida, no nível informal, familiar, utilizando seus referenciais pessoais de educação e cuidados, executando, assim, um trabalho permeado por subjetividade (BAZON 2001).

BAZON e BIASOLI-ALVES (2000a) chamam a atenção para as questões relativas à formação e reciclagem do pessoal encarregado pelos cuidados e pela educação cotidiana das crianças e adolescentes institucionalizados. Inicialmente, o profissional, denominado monitor, pela natureza do seu trabalho é um educador. Além disso, embora se atribua um caráter insignificante às tarefas realizadas por esse profissional, compartilhar experiências com as crianças e adolescentes pode tanto promover o desenvolvimento psicossocial e sua saúde integral, como prejudicá-los. Ao adulto cabe apoiar e estimular o desenvolvimento cognitivo, social e emocional, e somado a isso, cabe ao educador "transitar" pelos diversos universos e singularidades das crianças e adolescentes (LORDELO 1998; SANTOS e BASTOS 2002).

Mais do que explicações teóricas, os educadores necessitam ser conduzidos em suas ações diárias, de modo a compreender o impacto que suas ações podem ter, além de receberem apoio nas suas dificuldades, principalmente no que diz respeito ao desgaste emocional e ao sentimento de impotência ou onipotência, dependendo da situação (FARIA e STANISCI 1990; BAZON e BIASOLI-ALVES 2000a). No entanto, vivenciam a escassez de oportunidades de formação, acompanhamento ou supervisão e reciclagem. Quando ocorre um treinamento, normalmente, não decorre do levantamento das necessidades sentidas pelos profissionais na rotina institucional. O maior investimento tende a ser destinado ao trabalho de intervenção, desenvolvido por especialistas, como psicólogos, assistentes sociais, pedagogos, entre outros. 
$\mathrm{Na}$ fase de planejamento de um treinamento é importante observar os objetivos que se pretende alcançar e, principalmente, os conhecimentos prévios, as habilidades, as atitudes, os valores e a prática dos profissionais (PELICIONI 1995). O referencial teórico-prático deve ser condizente com os ideais de transformação (BAZON 2001).

Alguns países, como o Canadá e a França, têm se empenhado na formação dos educadores, sejam de nível técnico ou universitário, pois entendem que a qualidade dos serviços destinados às crianças e adolescentes em situação de risco está diretamente relacionada ao valor do seu quadro funcional (BAZON e BIASOLIALVES 2000a).

De um modo geral, nas entidades de abrigo não existem diretrizes claras, especificando as exigências para a seleção de pessoal e para sua inserção em processo de aperfeiçoamento contínuo (FARIA e STANISCI 1990).

E essa é a realidade dos abrigos de Vitória -ES: a admissão de trabalhadores não se dá por um processo de seleção bem definido; não há uma preparação que anteceda o início das atividades; assim como não há previsão de cursos de formação e de educação continuada.

BAZON e BIASOLI-ALVES (2000b) realizaram um trabalho de formação teórico-prática dos profissionais de uma entidade de abrigo em Ribeirão Preto - SP e na etapa de diagnóstico da situação resultante observaram, entre outros aspectos positivos, os seguintes resultados:

\section{Quanto aos objetivos da entidade:}

- ampliação da noção basicamente assistencial para uma de cunho educacional;

- estabelecimento de objetivos claros e específicos, associados à análise das necessidades das crianças e adolescentes. 


\section{Em relação à clientela:}

- compreensão da clientela como estando em processo de desenvolvimento;

- percepção das características individuais, rompendo com a política do "tudo igual para todo mundo";

- visão dos problemas como componente do "material de trabalho".

Quanto ao programa desenvolvido e aos métodos didáticos empregados:

- inclusão de atividades essencialmente lúdicas;

- implantação da filosofia de promoção do desenvolvimento integral;

- utilização dos eventos de rotina como momentos de aprendizagem.

Em relação à organização temporal e espacial:

- estabelecimento de metas para a desinstitucionalização de determinadas crianças;

- estabilização da rotina;

- organização espacial visando favorecer a privacidade/intimidade e também a vida em grupo.

Quanto ao relacionamento com a comunidade:

- intensificação do intercâmbio com as famílias, com as escolas, com a vizinhança e com os recursos da comunidade, sobretudo os de lazer.

Em relação ao papel do profissional, à convivência e às responsabilidades:

- percepção, por parte dos profissionais, do papel de educadores e da necessidade de um aperfeiçoamento profissional;

- estabelecimento de regras de convivência;

- definição de responsabilidades, considerando competências e interesses.

Os resultados alcançados pelas autoras confirmam a importância do desenvolvimento de atividades de formação dos profissionais que atuam em entidades de abrigo, pois permite, a partir de reflexões, a identificação das dificuldades vivenciadas e a construção conjunta das novas práticas, o que muito contribui com a qualidade da atenção que é destinada às crianças e adolescentes.

No entanto, para o êxito de um processo de capacitação é necessário um processo anterior de recrutamento e seleção de profissionais, capaz de definir o perfil 
(pessoal e profissional) exigido para o exercício das funções, incluindo tanto os técnicos, como os voluntários e o corpo administrativo (FARIA e STANISCI 1990).

Segundo PELICIONI (1995), há a necessidade de uma avaliação sistemática dos recursos humanos, tanto para corrigir intervenções inadequadas, como, também, para assegurar melhor atendimento.

NERY (1998) enfatiza a educação como a base para promoção do ser humano, o que reforça a necessidade de capacitar profissionais educadores e da área de saúde para atender à demanda social carente, principalmente a marginalizada. PINO (1990) cita que é tarefa de todos, sociedade civil e política, resgatar o princípio da igualdade de direitos e de oportunidade para as crianças e adolescentes, mas sobretudo dos educadores, cujo trabalho principal é a formação de novas gerações.

Um programa de educação continuada, voltado para os profissionais das entidades de abrigo, ao mesmo tempo em que beneficia os profissionais por meio de novos conhecimentos, de oportunidades para refletir tanto situações pessoais como profissionais, de maior segurança nas suas ações, de crescimento profissional, de realização, de valorização, entre outros aspectos positivos, beneficia as crianças e adolescentes, pois a aprendizagem é o caminho que permite ao sujeito transformar-se e transformar seu contexto (FEUERWERKER e col. 2000).

COSTA NETO e col. (1995) definem educação continuada como um processo organizado, permanente, sistematizado, direcionado a clientes institucionais, tendo em vista a real necessidade dos usuários. E para que o processo ensino-aprendizagem esteja vinculado com situações da prática e baseado em problemas da vida real, entende-se que a produção do conhecimento deva se dar de forma dinâmica, por meio da ação-reflexão-ação, ou seja, do aprender fazendo (FEUERWERKER e col. 2000). 
Esta moderna metodologia baseia-se na construção do conhecimento, uma vez que o processo de aprendizagem do adulto se dá pelo enfrentamento de desafios e de problemas (FEUERWERKER e col. 2000).

Somada à necessidade de um programa de educação continuada, a existência de uma política, que vise à melhoria do grau de satisfação do profissional, é essencial para se atingir maior qualidade na prestação de serviços (LENZI e CORRÊA 2000).

Mais uma vez, percebe-se a necessidade do estabelecimento de ações de decisão política, para dar sustentabilidade e qualidade na atenção destinada às crianças e adolescentes institucionalizados.

Nessa etapa, entende-se que os principais aspectos relacionados ao tema foram abordados, contextualizando-se a problemática, sem, contudo, ter-se a pretensão de esgotar o assunto.

Passa-se, então, à apresentação dos objetivos do estudo e da metodologia utilizada no desenvolvimento da pesquisa. 


\section{OBJETIVOS}




\section{OBJETIVOS}

Diante da escassez de literatura específica e de dados sobre a institucionalização de crianças e adolescentes e, também, sobre os trabalhadores que atuam em entidades de abrigo no Estado do Espírito Santo, pretendeu-se, com esta pesquisa, em parceria com o Centro de Apoio Operacional da Infância e da Juventude do Ministério Público do Estado do Espírito Santo (CAIJ/MPES), realizar uma aproximação dessa realidade, iniciando-se pelo município de Vitória. Entendeu-se que o primeiro estudo deveria ocorrer na capital do estado, de modo que os resultados pudessem tornar-se referência para o desenvolvimento de trabalhos futuros nos demais municípios capixabas.

Para viabilizar a investigação dessa realidade social, foram estabelecidos os seguintes objetivos:

- Caracterizar as sete entidades de abrigo existentes no município de Vitória - ES;

- Contextualizar a realidade de trabalho nas entidades de abrigo, referente aos aspectos administrativos;

- Identificar o perfil e a qualificação dos trabalhadores em exercício nos abrigos do município de Vitória-ES;

- Levantar a opinião dos trabalhadores sobre: a dinâmica de trabalho nas entidades de abrigo; a saúde das crianças e adolescentes institucionalizados;

- Propor alternativas para a melhoria do programa de atendimento às crianças e adolescentes. 


\section{DEFINIÇÃO DE TERMOS}




\section{DEFINIÇÃO DE TERMOS}

Com base no que foi exposto nos Títulos I e II, do Livro II do Estatuto da Criança e do Adolescente (ECA) de 1990, neste trabalho o termo entidade de abrigo ou, simplesmente, abrigo deve ser entendido como a entidade de atendimento para a qual são encaminhados crianças e adolescentes, em caráter provisório, por falta, omissão ou abuso dos pais ou responsáveis e que lhes deve oferecer medidas de proteção.

Apesar de ser utilizada no ECA a nomenclatura entidade de abrigo, o termo instituição é mais usualmente utilizado na literatura específica. Sendo assim, neste trabalho a palavra instituição é utilizada como sinônimo de entidade de abrigo. Conseqüentemente, a expressão crianças e adolescentes institucionalizados deve ser considerada como sinônimo de crianças e adolescentes sob medida de proteção em abrigo. 
METODOLOGIA 


\section{METODOLOGIA}

\section{TIPO DE ESTUDO}

O presente estudo caracteriza-se como uma pesquisa descritiva, de caráter exploratório, por tratar-se de uma primeira aproximação da realidade das entidades de abrigo da capital do Estado do Espírito Santo.

\section{POPULAÇÃO DE ESTUdO}

Participaram da pesquisa os trabalhadores que, à época do estudo, exerciam atividades nas sete entidades de abrigo do município de Vitória - ES, com a frequêencia mínima de uma vez ao mês, independentemente da existência de um contrato formal.

Em termos geográficos, as sete entidades estavam distribuídas em cinco diferentes bairros do município de Vitória - ES.

Do total de 73 trabalhadores, 67 participaram da pesquisa. Cinco trabalhadores não foram entrevistados porque estavam gozando férias ou estavam em licença no período da coleta de dados e um, por fazer parte do grupo que realizou a pesquisa.

De cada abrigo, foram entrevistados: a pessoa responsável e todos os funcionários em exercício.

Foram, também, apresentadas informações sobre 91 crianças e adolescentes institucionalizados, utilizando-se de dados secundários.

\section{INSTRUMENTOS E NATUREZA DOS DADOS}

Os dados primários foram coletados por meio de entrevistas semi-estruturadas, por permitirem a obtenção de respostas o mais próximo possível da realidade. 
Optou-se pela coleta de dados por meio de entrevista, em função das vantagens oferecidas pela técnica para este tipo de pesquisa, dentre elas: maior possibilidade de evitar recusa por parte do informante; maior flexibilidade de esclarecer as perguntas, como garantia de ser compreendido; oportunidade de observar a expressão corporal e facial do entrevistado, atitudes e condutas, assim como tonalidade de voz e ênfase ao responder (GIL 1994; MARCONI E LAKATOS 1996).

Foram utilizados dois roteiros de entrevista. $O$ primeiro roteiro foi aplicado com o profissional responsável por cada uma das entidades, com o propósito de conhecer as características dos abrigos e de levantar dados sobre aspectos administrativos, para poder contextualizar o ambiente de trabalho dos profissionais e de estada provisória das crianças e adolescentes (Anexo 2).

O segundo roteiro foi aplicado a todos os trabalhadores, inclusive os responsáveis pelas entidades. Por meio dele pretendeu-se conhecer o perfil, a qualificação profissional e as questões relativas à realidade de trabalho das pessoas responsáveis pela educação e pelos cuidados das crianças e adolescentes institucionalizados no município de Vitória - ES, além de suas opiniões sobre a dinâmica das entidades, sobre as relações interpessoais, a saúde das crianças e adolescentes e sua percepção sobre a necessidade ou não de implantação de um programa de formação continuada (Anexo 3).

Embora a institucionalização de crianças e adolescentes seja um processo muito dinâmico e influenciado historicamente por fatores sociais, familiares e jurídicos complexos, decidiu-se traçar o perfil das crianças e adolescentes abrigados nessas entidades em um dado momento, baseando-se em dados secundários do último levantamento realizado pelo Centro de Apoio Operacional da Infância e da Juventude (CAIJ) do Ministério Público do Estado do Espírito Santo (MPES), no período de outubro a dezembro de 2002. 


\section{PROCEDIMENTOS}

Dos documentos cedidos pelo CAIJ/MPES utilizaram-se os dados referentes ao sexo das crianças e adolescentes, data de nascimento, data de ingresso na entidade e data da coleta e realizou-se, pela primeira vez, a análise das informações obtidas.

A coleta de dados primários foi feita durante os meses de setembro, outubro e novembro de 2003 e dela participaram oito entrevistadoras, incluindo a pesquisadora, que foram preparadas, por meio de ampla discussão e estudo sobre o tema, para aplicação dos instrumentos de pesquisa. As entrevistas ocorreram nos locais de trabalho dos entrevistados, na maioria das vezes, durante o horário de expediente.

Para assegurar validade e precisão aos instrumentos de coleta de dados, foi realizado um pré-teste, antes de sua aplicação definitiva (Gil 1994). Nessa fase, por indicação do CAIJ, foram entrevistados os profissionais de um abrigo do município de Vila Velha - ES, situado na Grande Vitória, por apresentar características semelhantes aos abrigos de Vitória - ES. Após o pré-teste, foram feitas adequações no roteiro de entrevista destinado a todos os profissionais: uma questão foi retirada por ser considerada redundante, outra teve o enunciado modificado para torná-la mais clara e foram incluídas quatro questões para especificar a situação de saúde das crianças e adolescentes. Não houve modificação no roteiro destinado aos responsáveis.

Os abrigos foram contatados por meio de uma carta, que explicava os propósitos e a relevância da pesquisa, ressaltando a importância da colaboração dos entrevistados. A primeira visita a cada abrigo não foi previamente agendada. Temia-se que isso pudesse influenciar na dinâmica natural da vida diária da entidade.

Todos os participantes foram solícitos, porém em duas entidades as profissionais que atenderam as pesquisadoras pediram que voltassem em um outro dia, previamente agendado. No primeiro caso, foi devido à ausência da coordenadora naquele dia, o que gerou insegurança quanto à autorização por parte da funcionária. Posteriormente, fez-se 
contato telefônico com a coordenadora, que prontamente agendou uma data para a realização das entrevistas.

No segundo caso, embora a pessoa que recepcionou as pesquisadoras tenha se identificado como componente da coordenação do abrigo, optou por não autorizar, antes de telefonar para uma outra componente da coordenação, possivelmente hierarquicamente acima dela. Esta segunda pessoa, após se fazer referência à carta, proceder-se aos esclarecimentos sobre a pesquisa e se pedir autorização para participação, justificou que preferia agendar um outro dia, porque gostaria de informar às crianças, com antecedência, que receberiam visita. Explicou, ainda, que, na prática, a entidade funcionava como o lar daquelas crianças e que não considerava bom para as mesmas que recebessem visitas, sem serem avisadas.

Todos os entrevistados concordaram em assinar o termo de consentimento informado, após serem esclarecidos os objetivos da pesquisa e lhes ser garantida a preservação de suas identidades, pois foram utilizadas apenas as iniciais dos nomes para controle dos documentos.

As respostas foram registradas manualmente, no momento da entrevista. Diante da complexidade que envolvia o tema da pesquisa, optou-se por não utilizar aparelho gravador, por acreditar-se que poderia gerar constrangimento, insegurança e, talvez, até recusa por parte dos participantes, o que interferiria nos resultados da pesquisa.

Após a fase de coleta de dados, as informações geradas, a partir de cada questão, foram organizadas, de acordo com a semelhança das respostas, e, quando cabíveis, inseridas em figuras, quadros e tabelas.

Optou-se por apresentar a análise dos resultados juntamente com a discussão dos mesmos, com o objetivo de proporcionar melhor compreensão das informações, de possibilitar a comparação com opiniões e resultados obtidos por outros autores e, ainda, de conferir maior dinamicidade à leitura. A análise e a discussão dos resultados são apresentadas no próximo capítulo. 
ANÁLISE E DISCUSSÃO DOS RESULTADOS 


\section{ANÁLISE E DISCUSSÃO DOS RESULTADOS}

Apresenta-se, a seguir, a análise e discussão dos resultados obtidos na pesquisa.

\subsection{Capacidade instalada e distribuição dos trabalhadores}

Os abrigos possuíam capacidade instalada para atender a um total de 109 crianças e adolescentes, distribuídos como apresentado na Figura 1:

Figura 1: Capacidade instalada, por abrigo ( $\mathrm{N}=109)$.

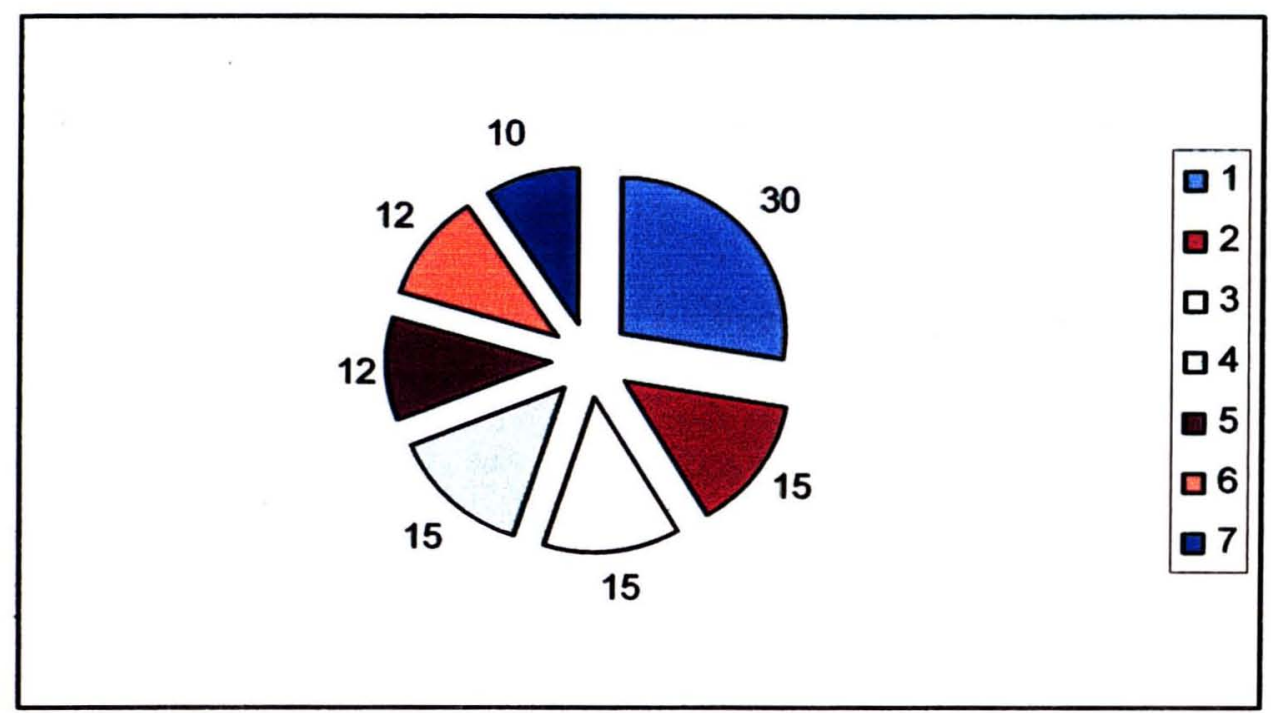

No período do levantamento de dados, um abrigo estava atendendo a um número de crianças e/ou adolescentes igual à sua capacidade total, dois estavam atendendo a um número maior que a sua capacidade e quatro atendendo a um número menor que a sua capacidade.

A distribuição dos trabalhadores entrevistados, por abrigo, é apresentada na Figura 2: 
Figura 2: Distribuição dos entrevistados, por abrigo ( $N=67)$.

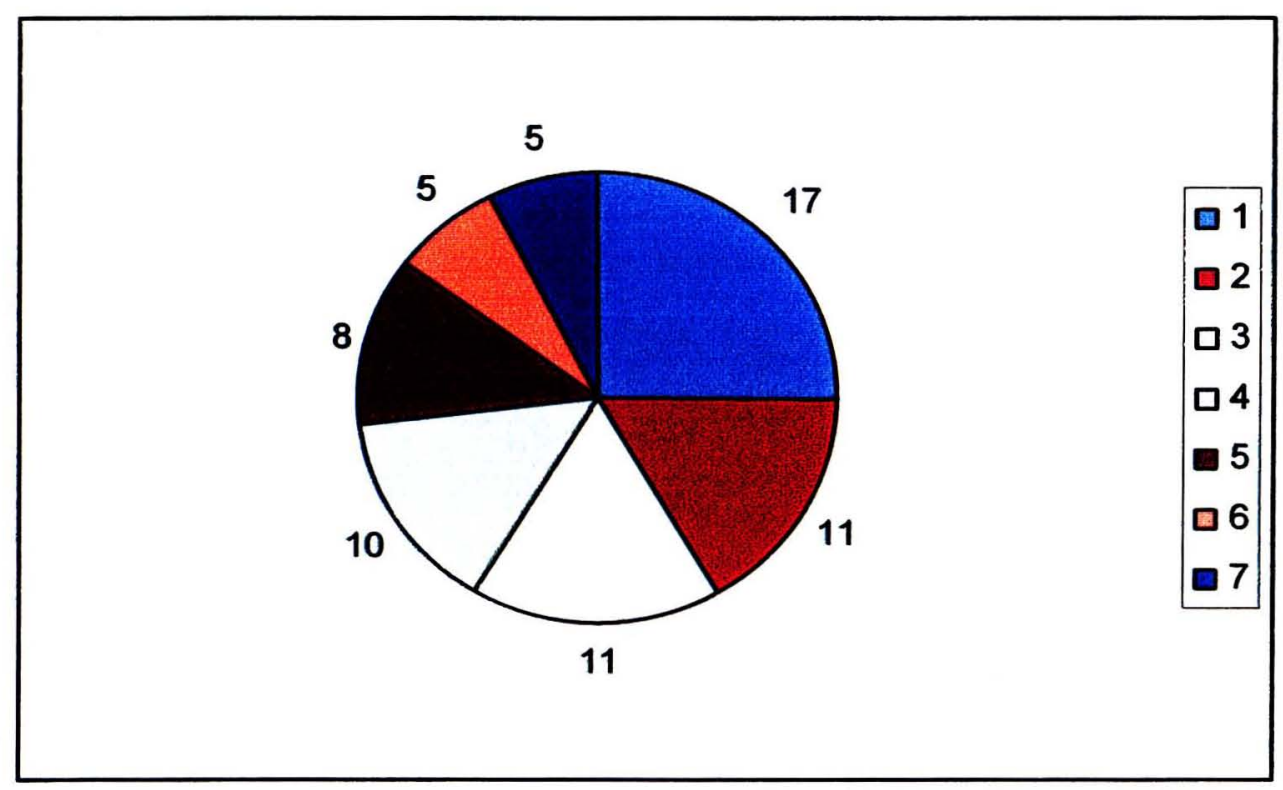

Em função do número de pessoas que trabalhavam nos abrigos, houve variação no número de entrevistados, tendo participado, respectivamente, 17 trabalhadores em uma entidade, 11, em dois abrigos, 10, em um abrigo, 8, em um outro e 5, em outras duas entidades.

\subsection{Crianças e adolescentes institucionalizados}

Como a chegada e a saída de crianças e adolescentes nas entidades de abrigo podem variar de um dia para o outro, dependendo das circunstâncias que levaram ao ato de institucionalização, da velocidade dos trâmites jurídicos e, também, devido à possibilidade de inserção em família substituta, os números apresentados sobre eles representam a realidade de um dado período de tempo, isto é, da época investigada, sem a pretensão de ser interpretada como sendo exatamente a realidade atual. Trata-se apenas de um retrato da dinâmica das entidades. 
Os resultados permitiram observar a variação que ocorre, principalmente, em relação à idade das crianças e adolescentes no ato da institucionalização e ao tempo de permanência das mesmas nas entidades de abrigo. A situação que deveria ser provisória na vida deles, na prática, é mais longa do que o previsto em lei e desejado pela sociedade.

As informações sobre a população atendida pelas entidades, o sexo e a faixa etária, a idade na data da coleta dos dados e no ato da institucionalização e, ainda, o tempo de institucionalização, foram organizadas em quadros, figuras e tabelas e são mostradas ao longo do texto. Antes, porém, apresenta-se a organização dos abrigos quanto ao público atendido, relacionando-se o sexo das crianças e adolescentes e a faixa etária estabelecida (Quadro 1).

\section{Quadro 1: Organização dos abrigos quanto ao público atendido, por sexo e faixa etária.}

\begin{tabular}{ccc}
\hline Abrigo & Sexo da população atendida & Faixa etária estabelecida \\
\hline 1 & Masculino & $6 \vdash 12$ anos \\
2 & Masculino & $7 \vdash 14$ anos \\
3 & Masculino & $14 \vdash 18$ anos \\
4 & Feminino & $0 \vdash 12$ anos \\
5 & Feminino & $12 \vdash 18$ anos \\
6 & Masculino e feminino & $0 \vdash 12$ anos \\
7 & Masculino e feminino & $0 \vdash 12$ anos \\
\hline
\end{tabular}

Quanto às características das crianças e adolescentes atendidos, cinco entidades recebiam crianças abandonadas, vítimas de maus tratos, negligência e violência sexual. Destas cinco, uma também recebia portadores de necessidades físicas especiais. Um abrigo recebia portadores de excepcionalidade mental, portadores de necessidades físicas especiais e portadores do vírus HIV. Um outro abrigo recebia somente portadores do vírus HIV. Estes dois últimos abrigos eram os que recebiam crianças e/ou adolescentes de ambos os sexos, ou seja, a característica da população atendida era definida por questões relacionadas à saúde e não ao sexo, como os demais.

Um dos abrigos, além do atendimento às crianças institucionalizadas, atendia a 102 (cento e dois) adolescentes nas suas famílias. 
Figura 3: Número de crianças e adolescentes institucionalizados, por $\operatorname{sexo}(\mathbf{N}=91)$.

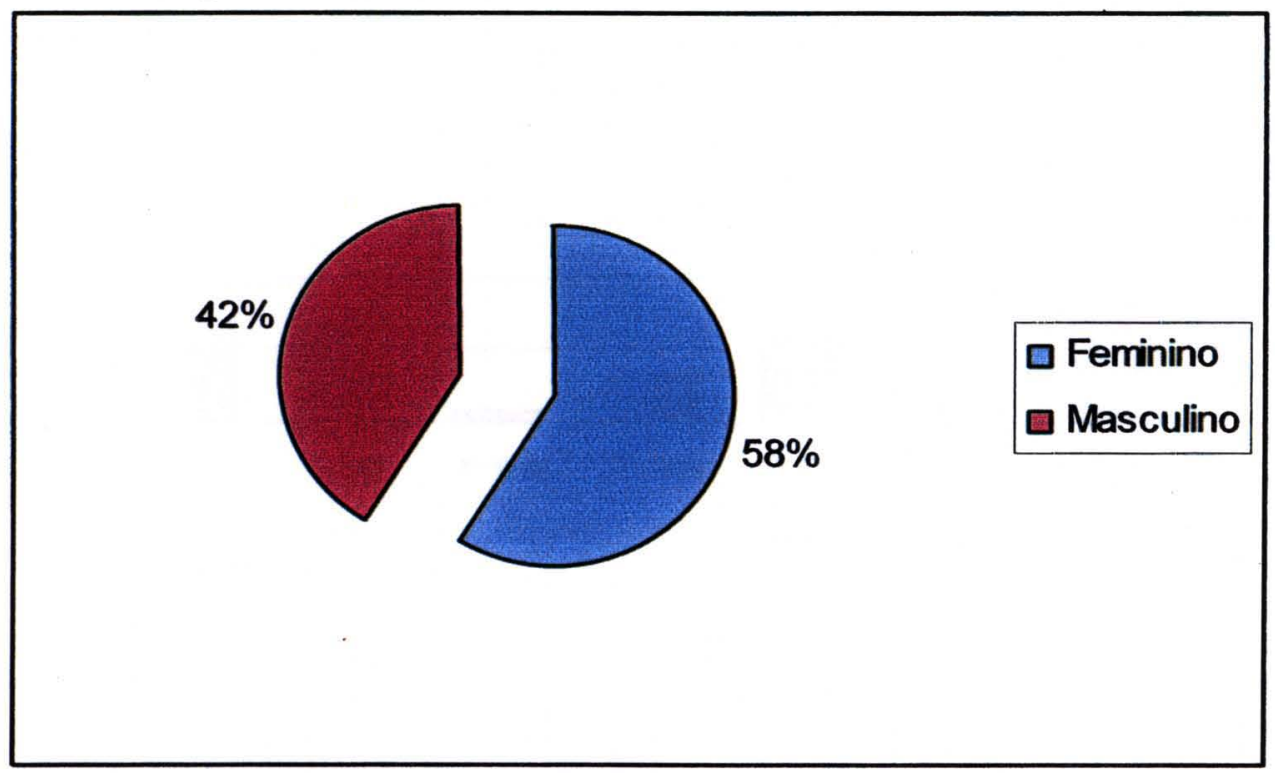

Fonte: CAIJ/MPES 2002

$\mathrm{Na}$ oportunidade do levantamento realizado pelo CAIJ/MPES, 91 crianças e adolescentes encontravam-se institucionalizados e mais da metade (58\%) pertencia ao sexo feminino (Figura 3); situação oposta à verificada por WEBER (1996b) no estado do Paraná.

Segundo PAPALIA e OLDS (1998), as meninas são as maiores vítimas no caso de abuso sexual, não havendo significativa diferença na ocorrência de maus tratos e nas demais formas de violência contra a criança e o adolescente, e isso talvez justifique os números encontrados nos abrigos de Vitória - ES. 
Figura 4: Número de crianças e adolescentes, por faixa etária ( $\mathrm{N}=91)$.

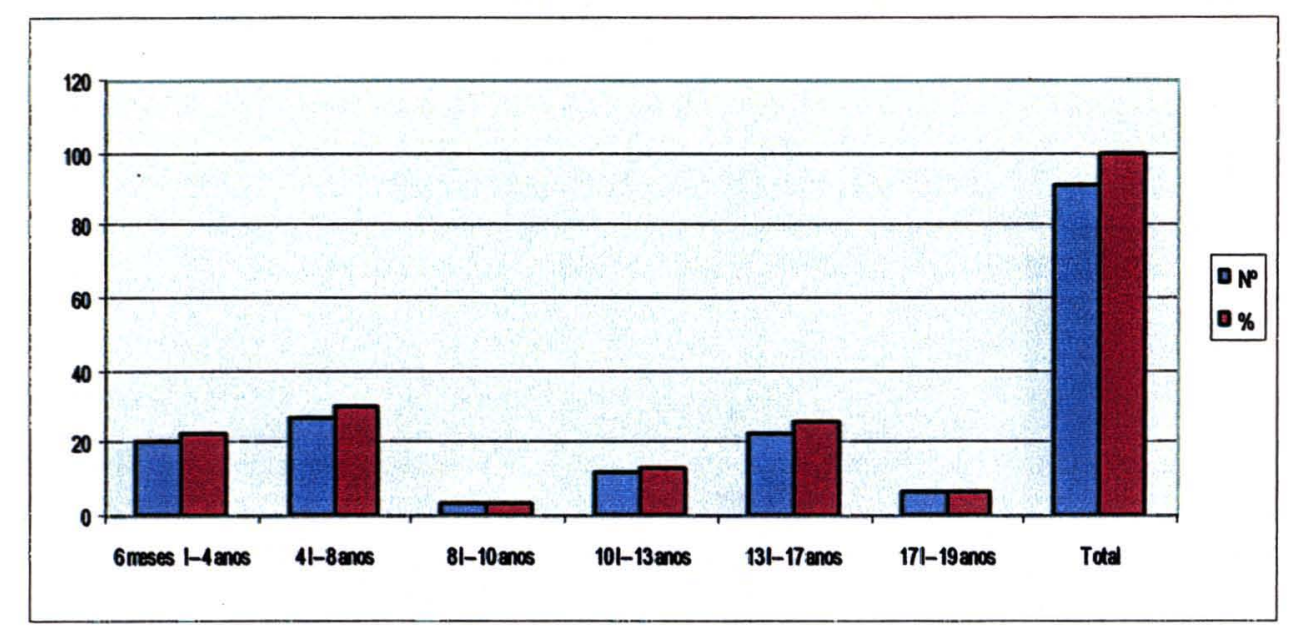

Fonte: CAIJ/MPES 2002

Do total de institucionalizados, somente 3 (3,3\%) crianças estavam com menos de um ano de idade, no período da coleta de dados (2002), não havendo criança com idade inferior a seis meses.

De acordo com a definição das fases da infância e da adolescência da Sociedade Brasileira de Pediatria (PERNETTA 1982), 22\% (20) das crianças institucionalizadas estavam na primeira infância (1mês $\vdash 4$ anos), 29,7\% (27), na segunda infância (4 anos $\vdash 8$ anos) e 3,3\% (3), na terceira infância ( 8 anos $\vdash 10$ anos), perfazendo um total de $55 \%$ de crianças.

Ainda em conformidade com a Sociedade Brasileira de Pediatria (PERNETTA 1982), 13,2\% (12) estavam na pré-adolescência (10 anos $\vdash 13$ anos), 25,2\% (23) eram adolescentes (13 anos $\vdash 17$ anos) e 6,6\% (6), adolescentes jovens (17 anos $\vdash 21$ anos), somando um total de $45 \%$ de pré-adolescentes e adolescentes.

A maior freqüência observada foi na faixa etária de 4 a 8 anos incompletos, seguida da faixa etária de 13 a 17 anos incompletos. 
Figura 5: Número de crianças e adolescentes, por idade, na data da institucionalização ( $\mathbf{N}=91)$.

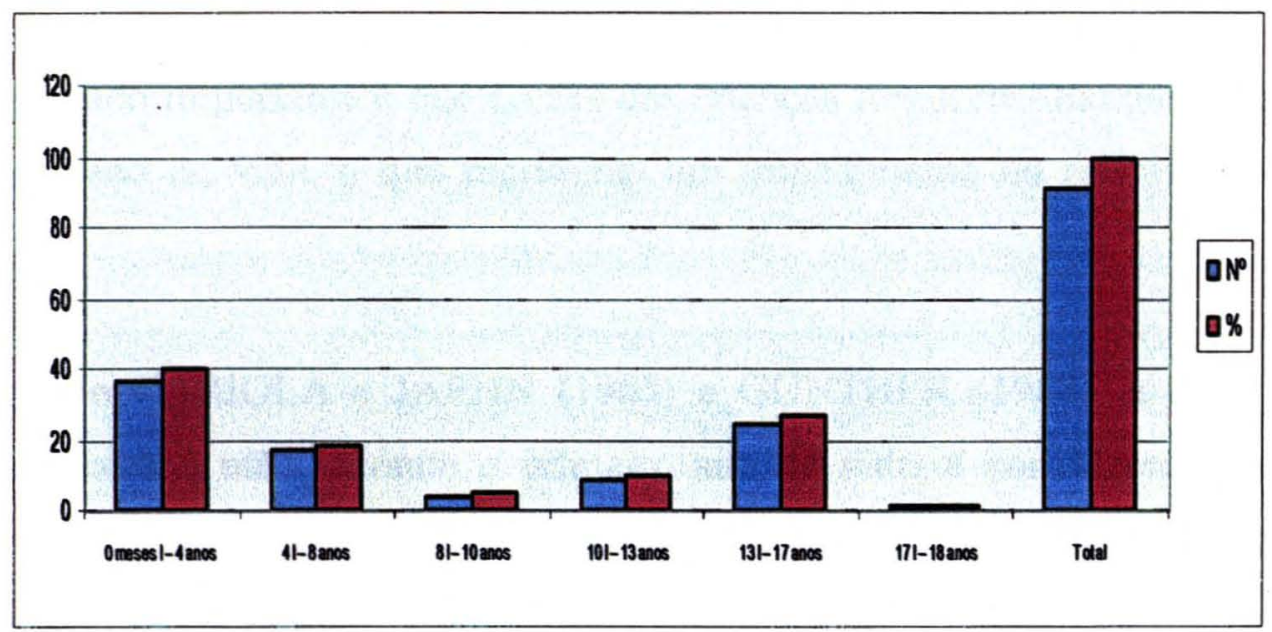

Fonte: CAIJ/MPES 2002

Do total de institucionalizados, $16,5 \%$ (15) ingressaram na entidade de abrigo antes de completar um ano de vida, 39,5\% (36), durante a primeira infância, 18,7\% (17), durante a segunda infância e 4,4\% (4), na terceira infância (Figura 5).

Entre aqueles com maior idade, nove (9,9\%) foram institucionalizados durante a pré-adolescência, vinte e quatro $(26,4 \%)$, na adolescência e apenas um $(1,1 \%)$ era adolescente jovem na data da institucionalização (Figura 5).

A maior freqüência foi observada na primeira infância, seguida da fase da adolescência. Estas duas fases da vida podem ser consideradas como críticas, em termos de risco pessoal e social.

Para MAURO (1998), DE ANTONI e KOLLER (2000) e LYRA e col. (2002), na infância, as fragilidades são inerentes da faixa etária, além de a criança apresentar um elevado grau de dependência em relação ao adulto, que necessita provê-la de cuidados e proteção. Já na adolescência, há menor necessidade de cuidados diretos, porém o diálogo é de fundamental importância. $\mathrm{O}$ adolescente é mais questionador e mais independente, o que pode gerar maior nível de atritos na família, podendo torná-lo vítima de violência e levá-lo a decidir sair de casa por conta própria, passando a vivenciar outros problemas, como fome, 
falta de moradia, entre outros, estando sujeito a inúmeros riscos, tanto internos (crise identitária), como externos.

Outro dado importante é que $16,5 \%$ das crianças foram institucionalizadas antes de completar um ano de vida, o que representa um impedimento no relacionamento com a família.

Segundo CARIOLA e JAEHN (1985) e GÜNTHER (1988), a falta de contato, especialmente com a mãe, durante o primeiro ano de vida, é considerada prejudicial ao desenvolvimento intelectual, social e afetivo, por ser uma fase de significativo desenvolvimento físico e emocional.

Figura 6: Distribuição das crianças e adolescentes, por tempo de institucionalização ( $\mathbf{N}=91)$.

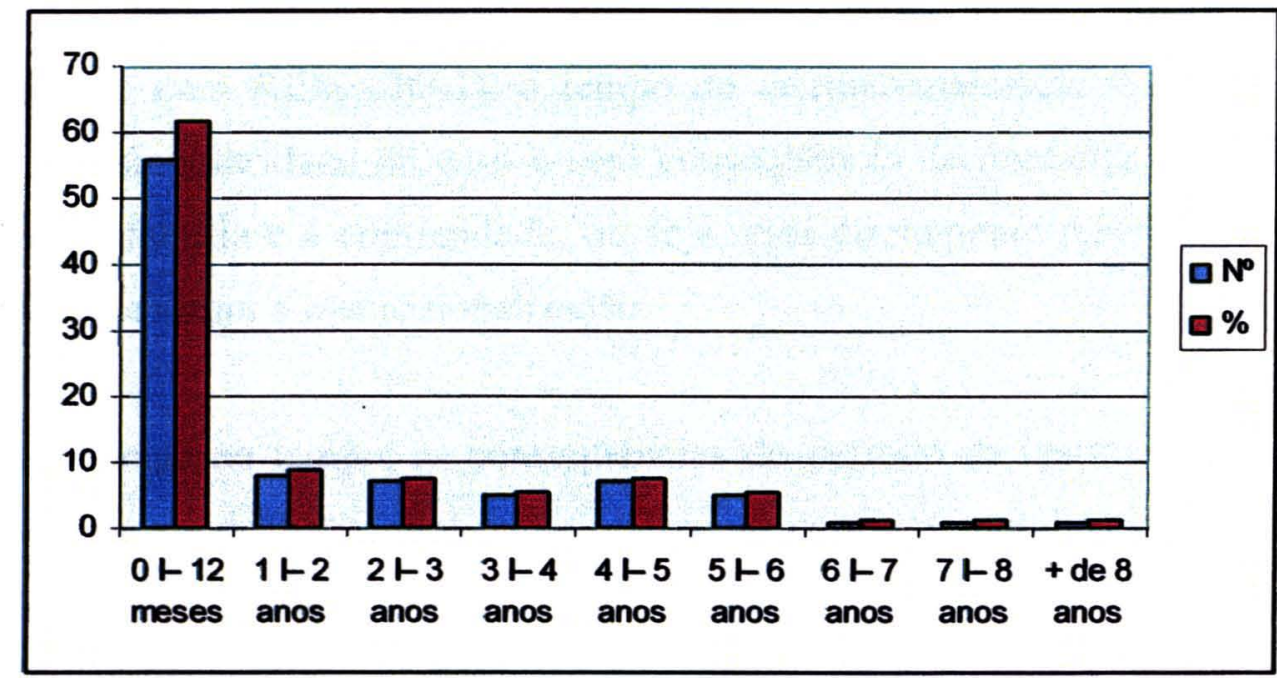

Fonte: CAIJ/MPES

Mais da metade $(61,5 \%)$ das crianças e adolescentes estava institucionalizada há menos de um ano e somente 3 (3,3\%) estavam institucionalizados há mais de seis anos, sendo que uma adolescente estava institucionalizada há 16 anos. Isso, provavelmente, ocorreu pelo fato de a menina ser portadora de deficiência mental, embora não fosse a única portadora desse tipo de deficiência encontrada nos abrigos estudados (Figura 6). 
Embora se saiba que o abrigo em entidade deve ser uma medida provisória e excepcional (Art. 101 do ECA, parágrafo único), na realidade, o tempo de permanência das crianças e adolescentes nas entidades é muito variável.

Segundo as responsáveis pelas entidades, em três abrigos, o tempo médio de permanência das crianças e adolescentes era de 1 a 2 anos e, em um abrigo, era de três anos. Em duas entidades, o tempo de permanência dependia de cada caso. As informações fornecidas foram, em parte, coerentes com os dados encontrados pelo CAIJ/MPES, pois as maiores freqüências ocorreram no período de até dois anos. Porém, freqüências de 7,7\% e $5,5 \%$ ocorreram nos períodos de dois a seis anos incompletos. Uma responsável não soube informar o tempo médio de permanência das crianças e adolescentes, o que é preocupante, pois trata-se de uma situação que pode influenciar diretamente o desenvolvimento, a saúde e a vida das crianças e adolescentes institucionalizados.

De acordo com REIS (2001), o tempo de institucionalização é determinado pela complexidade e singularidade do caso e será conseqüência da mudança das condições de proteção junto à família e à comunidade, ou seja, está diretamente relacionado à reversão dos motivos que levaram à institucionalização.

Paralelamente ao tempo, as conseqüências do período de institucionalização serão influenciadas pelo modo individual de se relacionar com essa condição e, também, serão reflexo da forma de condução por parte dos trabalhadores a que estão subordinados. Por isso, as condutas necessitam ser maduras e responsáveis, resultantes de conhecimento e experiência, além de fundamentadas em uma proposta pedagógica.

\subsection{Identificação dos Abrigos}

As informações fornecidas pelas responsáveis das sete entidades de abrigo foram importantes para a caracterização do perfil dessas gestoras e para a compreensão da forma de organização dos abrigos. 


\subsubsection{Sobre as responsáveis}

As sete responsáveis pelos abrigos eram do sexo feminino. Cinco exerciam a função de coordenadora, uma era a presidente da entidade e outra não especificou a sua função no abrigo, possivelmente por sua função estar vinculada à instituição mantenedora.

Quanto à escolarização, cinco concluíram o ensino médio, uma possuía curso superior incompleto e somente uma possuía curso superior completo. Tal resultado indica um baixo nível de escolarização, se avaliado o grau de conhecimento necessário para se estar à frente de entidades com tamanha responsabilidade social e educacional.

Em relação ao tempo de trabalho, quatro das sete gestoras atuavam há menos de dois anos no abrigo, sendo que uma delas trabalhava há apenas um mês.

Duas responsáveis trabalhavam há seis anos no abrigo, mas somente uma exercia a função por igual período, a outra exercia a função há menos de dois anos, assim como as quatro anteriormente citadas. Somente uma gestora trabalhava no abrigo e exercia a função há dez anos.

Pode-se questionar o critério de seleção para o exercício de função gerencial nas entidades de abrigo, pois, pelo menos na maioria dos casos, a formação educacional e o tempo de experiência não foram pré-requisitos para a indicação das responsáveis. Aliada à falta de qualificação de nível superior, o tempo de trabalho relatado parece insuficiente para se adquirir experiência em tal campo de atuação.

\subsubsection{Sobre o Abrigo}

Segundo as responsáveis, todos os abrigos eram regularmente constituídos e possuíam registro no Conselho Municipal de Direitos da Criança e do Adolescente, mas somente três possuíam Regimento Interno. 
Todas as entidades de abrigo eram Organizações Não Governamentais (ONGs), sendo quatro de natureza religiosa e três de natureza laica.

Quanto aos recursos obtidos para a manutenção dos abrigos e cobertura das despesas, seis abrigos aceitavam contribuições de doadores espontâneos e/ou realizavam campanhas eventuais, quatro recebiam contribuições de associados, quatro eram subvencionados por alguma Secretaria Municipal e três recebiam auxílio de outras ONGs.

Nos sete abrigos existiam prontuários individualizados das crianças e adolescentes, nos quais constavam documentos como: certidão de nascimento, cartão de vacina/saúde, documentos pessoais (C.I., CPF, título de eleitor), encaminhamento do Juizado ou outro, histórico clínico, relatórios de profissionais especializados, entre outros. Observou-se que havia uma variação dos documentos constantes em cada prontuário, devido à diversidade dos casos e das circunstâncias em que as crianças ou adolescentes chegavam aos abrigos. Em um abrigo, o prontuário possuía apenas informações relativas às condições de saúde.

Em mais de dois terços dos casos $(68,8 \%)$, os responsáveis pelo encaminhamento das crianças e adolescentes para os abrigos eram as autoridades judiciárias e os conselhos tutelares; situação diferente da encontrada por WEBER (1999), em que a maioria das crianças chegava às instituições levadas por suas próprias famílias. Nos demais $31,2 \%$ dos casos, o encaminhamento ocorria por ação do projeto social de abordagem a crianças e adolescentes de rua, pela família, pelo serviço social de hospitais ou por outro abrigo.

Para administração das entidades, realização das tarefas diárias, acompanhamento e cuidado das crianças e adolescentes, os abrigos contavam com um quadro de trabalhadores (Quadro 2): 


\section{Quadro 2: Categorias profissionais constantes no quadro de funcionários dos abrigos.}

\begin{tabular}{lc}
\hline Categorias profissionais & $\mathbf{N}^{\mathbf{O}}$ \\
\hline educador/monitor & 7 \\
trabalhador administrativo & 5 \\
motorista & 4 \\
assistente social & 3 \\
servente & 3 \\
mãe social & 2 \\
plantonista & 2 \\
responsável pela cozinha & 2 \\
responsável pela higienização das roupas & 2 \\
pai social & 1 \\
segurança & 1 \\
\hline Total & 32 \\
\hline
\end{tabular}

Pode-se observar que a única categoria profissional existente em todas as entidades era a de educador/monitor.

Cinco abrigos eram administrados por trabalhadores de seus quadros, enquanto dois eram administrados por pessoas das ONGs que os mantinham. Nestes dois casos, os trabalhadores exerciam as suas atividades fora dos abrigos e, por isso, participavam e vivenciavam menos a rotina do abrigo. Aqui cabe fazer algumas reflexões: como gerenciar vidas, sem, de perto, conhecê-las? Como saber que necessidades as crianças e adolescentes têm, sem conviver com eles? Como saber o que sentem, o que esperam do futuro, sem ter um contato mais próximo com eles? Como orientá-los e conduzi-los, sem saber por onde desejam ir ou onde pretendem chegar?

Quatro entidades contavam com motorista. Três possuíam em seus quadros assistentes sociais contratadas. Três entidades contavam com trabalhadores para exercer especificamente a função de servente e duas entidades contavam com responsáveis pela cozinha e higienização das roupas. 
Nos demais abrigos, os cuidados com a casa, com a alimentação e a roupa eram exercidos pelo pai e pelas mães sociais", pelos educadores/monitores, auxiliados pelas crianças e adolescentes.

Um abrigo contava com mãe social e outra contava com casal social, ou seja, pai e mãe social. Somente um abrigo contava com a proteção adicional de seguranças.

É importante observar que os abrigos não possuiam profissionais das áreas de psicologia e pedagogia contratados (Quadro 2). Alguns abrigos contavam com profissionais dessas áreas, mas que atuavam como voluntários (Quadro 3).

\section{Quadro 3: Categorias profissionais dos voluntários que atuavam nos abrigos.}

\begin{tabular}{ll}
\hline Categorias profissionais & $\mathbf{N}^{\mathbf{}}$ \\
\hline psicólogo & 2 \\
assistente social & 1 \\
pedagogo & 1 \\
estudante de psicologia (por meio de convênio) & 1 \\
\hline Total & $\mathbf{5}$ \\
\hline
\end{tabular}

Contando com a atenção de voluntários, um abrigo tinha o atendimento de um psicólogo, um assistente social e um pedagogo. Outro abrigo contava com um psicólogo. Um terceiro contava com atendimento psicológico realizado por meio de convênio, atendimento este realizado por quatro estagiários de psicologia (Quadro 3).

O trabalho voluntário, certamente, tem valor inestimável, pois demonstra a boa vontade de auxiliar o próximo. No entanto, a falta de um vínculo formal pode gerar, por motivos diversos, a descontinuidade do atendimento. No caso de crianças e adolescentes institucionalizados, percebe-se a necessidade de acompanhamento psicológico e educacional ininterruptos, o que, talvez, pudesse acontecer, se os profissionais pertencessem ao quadro de contratados.

\footnotetext{
" Pais e mães sociais são profissionais contratados para residirem nos abrigos, que têm, como atribuições, as funções naturais de pais e mães de famílias, ou seja, responsabilidades de cuidados com as crianças e com a "casa", proteção, orientação e outras.
} 
Como uma atenção complementar, as crianças e adolescentes, também, tinham acesso a atendimentos fora das instalações dos abrigos (Quadro 4).

\section{Quadro 4: Tipos de atendimento realizados fora das entidades de abrigo.}

\begin{tabular}{lc}
\hline Atendimento fora do abrigo & $\mathbf{N}^{\mathbf{0}}$ \\
\hline médico & 7 \\
odontológico & 7 \\
psicológico & 6 \\
fisioterápico & 2 \\
serviço social & 2 \\
fonoaudiológico & 1 \\
pedagógico & 1 \\
terapêutico ocupacional & 1 \\
\hline Total & $\mathbf{2 7}$ \\
\hline
\end{tabular}

Todos os abrigos contavam com atendimento médico e odontológico; seis, com atendimento psicológico; dois, com atendimento fisioterápico; dois, com atendimento de serviço social; um, com atendimento fonoaudiológico; um, com atendimento pedagógico; e um, com atendimento terapêutico ocupacional (Quadro 4).

Percebe-se que alguns tipos de atendimento são privilegiados em detrimento de outros, possivelmente, por maior oferta de profissionais em determinadas áreas, principalmente, no serviço público de atenção à saúde. No entanto, se o objetivo é promover atenção integral às crianças e adolescentes, todos deveriam ter direito de acesso aos profissionais, certamente, desde que suas necessidades individuais requisitassem. $O$ ideal seria o atendimento por equipe multidisciplinar, em trabalho integrado.

Porém, a realidade de dificuldade de acesso aos serviços não atinge somente os institucionalizados, mas a maioria da população brasileira, em função de uma realidade social instalada. 


\subsubsection{Sobre o Plano de Trabalho}

A organização da rotina diária dos abrigos pareceu semelhante. $O$ dia-a-dia era preenchido com idas à escola e atividades escolares ou de reforço, refeições, banhos, atividades religiosas e esportivas, auxílio nas tarefas da casa, entre outras. Pôde-se verificar uma sistematização das práticas, com definição de horários, como, por exemplo, para assistir televisão e descansar; regras, como para receber visitas; e "obrigações", como a execução de tarefas da casa, algumas vezes em regime de escala, para propiciar o revezamento.

Certamente que, no convívio social, há necessidade de serem estabelecidas regras para o bem viver. Isso acontece em qualquer grupo, seja escolar, familiar ou outro, inclusive o institucional. No entanto, é preciso observar como se dá a construção das regras, quem participa de sua elaboração e até que ponto elas são flexíveis e passíveis de avaliação e reformulação.

No que tange ao documento que norteia as ações nas entidades de abrigo, segundo as responsáveis, três entidades possuíam Plano de Trabalho* compatível com os princípios do Estatuto da Criança e do Adolescente (ECA), três não possuíam Plano de Trabalho e uma não soube informar. Aqui, mais uma vez, aparece a desinformação da gestora sobre tema de grande relevância.

\footnotetext{
* O Plano de Trabalho está previsto no Art. 91 do ECA, em seu Parágrafo único, e seus princípios previstos no Art. 92 do mesmo Estatuto.
} 


\section{Quadro 5: Participação na elaboração do Plano de Trabalho dos abrigos.}

\begin{tabular}{ll}
\hline \multicolumn{1}{c}{ Participação na elaboração do Plano de Trabalho } \\
\hline Abrigo 1 & $\begin{array}{l}\text { diretoria } \\
\text { assistente da mantenedora } \\
\text { responsável pelo abrigo } \\
\text { pedagoga da escola } \\
\text { comunidade }\end{array}$ \\
Abrigo 2 & $\begin{array}{l}\text { equipe técnica } \\
\text { crianças e adolescentes }\end{array}$ \\
Abrigo 3 & $\begin{array}{l}\text { diretoria } \\
\text { responsável pelo abrigo }\end{array}$ \\
\hline
\end{tabular}

Dos três abrigos que possuíam Plano de Trabalho, somente um contou com a participação de diferentes segmentos, envolvendo a diretoria, a assistente da mantenedora, a responsável pelo abrigo, a pedagoga da escola e a comunidade, embora se perceba que não houve a importante participação da equipe técnica e das crianças e adolescentes. Por outro lado, em outro abrigo, participaram somente a equipe técnica e as crianças e adolescentes. No terceiro abrigo, a elaboração ficou restrita à diretoria e à responsável pelo mesmo (Quadro 5).

A participação das crianças e adolescentes na elaboração de regras e propostas para as entidades de abrigo, embora ainda incipiente, representa grande conquista diante do observado por WEBER (1996b) e GOFFMAN (2001), que dizem que nas instituições tudo é previamente estipulado e sem a participação dos institucionalizados.

O Plano de Trabalho deve prever, além das normas de funcionamento do abrigo, a proposta pedagógica de atenção às crianças e adolescentes, o planejamento e acompanhamento individualizado de cada caso, a participação da comunidade no processo educativo, entre outros princípios previstos no Art. 92 do ECA. Neste caso, o ideal seria que todos os envolvidos na dinâmica das entidades de abrigo pudessem participar da elaboração do Plano de Trabalho, pois a participação na construção de um documento de tal importância leva ao maior comprometimento e envolvimento, além de torná-lo mais rico, por incluir diversos "olhares" sobre as questões ali abordadas. 
Para FARIA e STANISCI (1990), todos os agentes devem participar como coresponsáveis no planejamento, execução e avaliação das práticas institucionais.

Ao serem questionados sobre a participação na elaboração do Plano de Trabalho da entidade, $48(77,4 \%)$ trabalhadores informaram que não participaram e $14(22,6 \%)$ disseram ter participado. Porém, em dois casos, os trabalhadores afirmaram ter participado da elaboração do Plano de Trabalho, embora as responsáveis pelos respectivos abrigos tenham informado que não havia tal documento. Em outro caso, o trabalhador disse ter participado da elaboração, enquanto os demais colegas afirmaram não ter participado ou que o documento, também, não existia. Cinco trabalhadores disseram que não havia Plano de Trabalho no abrigo.

Embora somente três entidades possuíssem tal documento, todos os trabalhadores (67) foram questionados sobre como avaliavam o Plano de Trabalho do abrigo. Do total, 45 $(67,1 \%)$ disseram ser bom, $15(22,4 \%)$ avaliaram como regular e 2 (3\%) consideraram insatisfatório. Quatro (6\%) trabalhadores disseram que não havia Plano de Trabalho e 1 $(1,5 \%)$ não respondeu. Vale ressaltar que uma das pessoas que consideraram o Plano de Trabalho insatisfatório ocupava a função de coordenadora. Tal fato conduz a uma reflexão: quando um gestor não está satisfeito com um documento que orienta ações em determinada unidade, é praxe que se tome medidas no sentido de promover uma avaliação, juntamente com o grupo de trabalhadores, e propor a sua reconstrução. No entanto, parece que isso não era feito.

Os resultados obtidos nas questões sobre Plano de Trabalho demonstram que nem todos os trabalhadores tinham ciência do que era o documento, embora previsto em Lei e de amplitude e importância muito além das questões operacionais da vida diária. Pareceu haver confusão entre Plano de Trabalho e o estabelecimento de rotina de trabalho. 
Para verificar se os trabalhadores tinham conhecimento sobre o conteúdo do Estatuto da Criança e do Adolescente (ECA), foi questionado se eles participavam de reuniões de estudo sobre o mesmo. Trinta e sete trabalhadores $(61,7 \%)$ informaram que participavam de reuniões de estudo sobre o Estatuto e vinte e três $(38,3 \%)$ disseram que não participavam. Sete funcionários informaram que não eram promovidas tais reuniões.

No entanto, observou-se incoerência nas respostas, uma vez que, em seis dos sete abrigos, parte dos trabalhadores disse que participava e a outra afirmou não participar. Além disso, em quatro abrigos, alguns trabalhadores disseram que não havia reuniões de estudo, enquanto outros confirmaram a sua participação. Na tentativa de explicar a divergência nas respostas, pode-se pensar que, talvez, somente um determinado grupo dentro dos abrigos tivesse acesso a discussões sobre temas abordados no ECA, mas, também, pode ter acontecido uma tentativa de fazer parecer que havia debate sobre o tema, por saber que seria importante, mas que, de fato, não acontecia.

Ainda dentro das previsões do ECA (Art. 92, inciso III), para garantir o atendimento personalizado das crianças e adolescentes, é importante haver um plano individual de atendimento nos abrigos. No entanto, somente duas responsáveis confirmaram a existência de tal plano, três disseram não existir e duas não souberam informar. Nas entidades onde havia plano individual de atendimento, as responsáveis afirmaram que as crianças e adolescentes participavam da elaboração do mesmo, por meio de conversa, o que é de grande valia para os mesmos.

Segundo WEBER (1999), é importante para as crianças e adolescentes terem ciência de suas situações e poderem manifestar seus desejos e suas opiniões, de modo a terem, dentro do possível, o controle sobre o encaminhamento de suas próprias vidas, evitando que teçam fantasias sobre acontecimentos futuros. 


\section{Figura 7: Participação dos trabalhadores na avaliação da situação das crianças e adolescentes $(\mathbf{N}=\mathbf{6 5})$.}

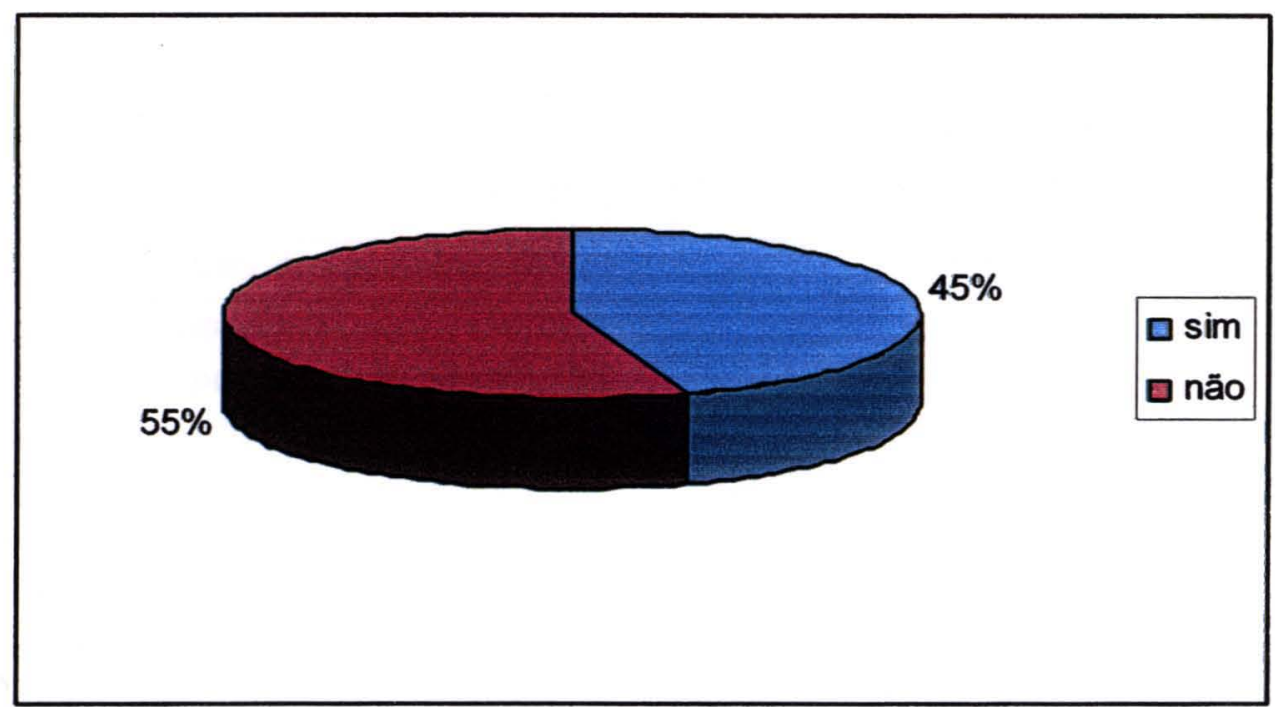

Questionados sobre a participação na avaliação das crianças e adolescentes, avaliação esta incluindo questões comportamentais, de relacionamento, escolares, de saúde, entre outras, $55 \%$ (36) disseram que não participavam e 45\% (29) afirmaram que participavam. Dois trabalhadores disseram que não havia esse tipo de avaliação (Figura 7).

Tabela 1: Forma de participação dos entrevistados na avaliação da situação das crianças e adolescentes.

\begin{tabular}{lcc}
\hline Forma de participação & $\mathbf{N}^{\circ}$ & $\%$ \\
\hline em reuniões com equipe & 12 & 40,0 \\
passando informações, por meio de relatórios ou verbalmente & 11 & 36,7 \\
discussão com outro trabalhador & 4 & 13,3 \\
encaminhando para outro trabalhador & 2 & 6,7 \\
individual e pessoalmente & 1 & 3,3 \\
\hline Total & $\mathbf{3 0}$ & $\mathbf{1 0 0 , 0}$ \\
\hline & \multicolumn{2}{c}{ (múltipla escolha) }
\end{tabular}

A forma de participação mais citada sobre a avaliação da situação das crianças e adolescentes foi a presença ativa em reuniões (40\%), seguida da participação pelo fornecimento de informações, por meio de relatórios ou verbalmente $(36,7 \%)$. Outros 
participavam discutindo as questões com colega de trabalho $(13,3 \%)$ ou encaminhando os casos para outros trabalhadores $(6,7 \%)$. Em um caso $(3,3 \%)$, o trabalhador discutia as questões diretamente com a criança ou adolescente (Tabela 1).

Tabela 2: Motivos da falta de participação na avaliação da situação das crianças e adolescentes alegados pelos entrevistados.

\begin{tabular}{lcc}
\hline Motivo da falta de participação & $\mathbf{N}^{\circ}$ & $\%$ \\
\hline por ser realizada por outro trabalhador & 27 & 75,0 \\
por estar há pouco tempo no trabalho & 3 & $\mathbf{8 , 3}$ \\
por incompatibilidade de horário & 2 & 5,5 \\
por exercer atividades externas & 1 & 2,8 \\
porque não é permitido & 1 & 2,8 \\
não foi especificado & 1 & 2,8 \\
não respondeu & 1 & 2,8 \\
\hline Total & $\mathbf{3 6}$ & $\mathbf{1 0 0 , 0}$ \\
\hline
\end{tabular}

Três quartos (75\%) dos trabalhadores que não participavam da avaliação das crianças e adolescentes justificaram que isso acontecia porque a avaliação era realizada por outro trabalhador. Outras justificativas citadas foram o pouco tempo de trabalho no abrigo $(8,3 \%)$ e o horário de trabalho $(5,5 \%)$, no caso, plantão noturno. A falta de participação alegada por um trabalhador foi o fato de exercer as suas atividades profissionais fora do abrigo e um outro trabalhador justificou não ser permitida a sua participação (Tabela 2).

Nas informações referentes à existência de plano de trabalho, de plano individual de atendimento e de avaliação das crianças e adolescentes, chamou a atenção o fato de uma responsável não saber se o primeiro documento existia, de duas não saberem se havia um plano de atendimento individual e de uma não participar da avaliação por exercer suas atividades fora do abrigo. Além de essenciais no processo de acompanhamento da vida das crianças e adolescentes, os documentos são previstos por Lei. Assim, caberia a todos os responsáveis terem ciência e controle sobre os mesmos, além de garantirem e valorizarem a participação de todos os trabalhadores do abrigo, em função da riqueza que diferentes percep̧̧ões podem proporcionar na construção de processos de atuação e de avaliação. $O$ fato ressalta a importância dos gestores trabalharem junto à sua realidade de atuação e não apenas de gerirem a distância, uma vez que as questões burocráticas não podem ser mais 
valorizadas do que o desenvolvimento cognitivo, físico, psicológico e social das crianças e adolescentes.

Outro aspecto observado, no que se refere a uma atenção personalizada, visando à preservação da individualidade e manutenção da identidade, foi que em todos os abrigos as crianças e adolescentes faziam uso de roupa habitual, não sendo utilizado uniforme. Além disso, as responsáveis disseram que haviam armários com compartimentos individualizados e, em um dos abrigos, existia um armário por quarto, para cada duas adolescentes. No entanto, houve relatos de que as roupas que pertenciam às crianças e adolescentes eram aquelas que haviam levado para as entidades, sendo, as demais, cedidas para uso durante a estada no abrigo.

Situação semelhante foi observada por KOSMINSKI (1993), na qual as crianças não tinham a posse das roupas que usavam, porém, ainda mais grave, uma vez que em um passado recente, elas não possuíam, sequer, objetos de uso pessoal.

Por considerarem importante, todas as responsáveis afirmaram que havia um processo de recepção e acolhimento na chegada das crianças e adolescentes aos abrigos, embora uma não soubesse de que forma acontecia este processo. Novamente, o desconhecimento reforça a necessidade do gestor vivenciar o dia-a-dia do abrigo.

Quadro 6: Formas de recepção e acolhimento das crianças e adolescentes.

\begin{tabular}{lc}
\hline Formas de recepção e acolhimento & $\mathbf{N}^{\circ}$ \\
\hline apresentação da casa & 3 \\
apresentação das outras crianças e adolescentes & 3 \\
providência de aposento, vestimentas e objetos pessoais & 3 \\
cuidados de higiene & 2 \\
alimentação & 1 \\
apresentação das normas da casa & 1 \\
conversa & 1 \\
preparação das crianças que já estão no abrigo & 1 \\
\hline Total & 15 \\
\hline
\end{tabular}


Em três abrigos, acontecia a apresentação da casa, a apresentação das outras crianças e adolescentes e a providência de aposentos, vestimentas e objetos pessoais. Dois abrigos promoviam os cuidados de higiene. Um abrigo oferecia alimentação; um conversava com os recém-chegados; um apresentava as normas da casa; e um preocupavase em preparar as crianças e adolescentes que já estavam no abrigo para receber os que iriam chegar (Quadro 6).

Dos 67 trabalhadores, $46(70,8 \%)$ disseram que participavam do acolhimento e 19 $(29,2 \%)$ não participavam ou ainda não tinham participado, por estar há pouco tempo na atividade. Dois trabalhadores disseram que não havia acolhimento.

Tabela 3: Formas de participação dos entrevistados no acolhimento de crianças e adolescentes.

\begin{tabular}{llc}
\hline Forma de participação & $\mathbf{N}^{\mathbf{0}}$ & $\%$ \\
\hline conversa / atenção / carinho & 18 & 22,5 \\
realização de cuidados de higiene / vestimenta & 14 & 17,5 \\
providência de alimentação & 12 & 15,0 \\
explicação das normas da casa & 10 & 12,5 \\
pela busca de informações sobre a história da criança ou adolescente & & \\
/ entrevista & 6 & 7,5 \\
apresentação da casa & 5 & 6,2 \\
apresentação das demais crianças/adolescentes & 4 & 5,0 \\
apresentando-se & 4 & 5,0 \\
participação não especificada & 3 & 3,8 \\
abrindo o portão & 1 & 1,3 \\
envolvendo-se com as questões escolares & 1 & 1,3 \\
preparando as crianças que já estão no abrigo & 1 & 1,3 \\
fazendo festa & 1 & 1,3 \\
\hline Total & $\mathbf{8 0}$ & $\mathbf{1 0 0 , 0}$ \\
\hline
\end{tabular}

As formas de participação citadas pelos trabalhadores foram coerentes com as informadas pelas responsáveis das entidades, percebendo-se uma maior preocupação em conversar, dar atenção e carinho (22,5\%), seguida por realização de cuidados de higiene e providência de vestimentas $(17,5 \%)$, providência de alimentação $(15,0 \%)$ e explicação das normas da casa (12,5\%), entre outras condutas (Tabela 3 ). 
Apesar da medida de proteção de abrigo em entidade ser necessária em determinados casos, por falta, omissão ou abuso dos pais ou responsáveis, é atribuição das entidades incentivar a preservação dos vínculos familiares. No entanto, em somente três das entidades de abrigo havia um programa de incentivo à preservação desses vínculos. Destes três abrigos, um incentivava somente as famílias que realizavam visitas, outro auxiliava financeiramente as famílias para estimular as visitas e o terceiro não especificou a forma de incentivo.

É importante que o incentivo aconteça, tanto em função das questões afetivas e emocionais, como numa tentativa de abreviar o tempo da criança ou adolescente na instituição. Caso contrário, lamentavelmente, a tendência é haver um afastamento, dificultando o regresso ao lar de origem.

No caso de quatro entidades, a participação dos pais e/ou familiares se dava por meio de visitas realizadas no próprio abrigo. Em um abrigo, a criança ou adolescente realizava visita na residência dos pais ou familiares. Em um abrigo, alguns pais ou familiares mantinham contato telefônico. Uma responsável não sabia a forma de participação dos pais e/ou familiares. No caso de dois abrigos, não havia participação dos pais e/ou familiares.

WEBER (1995) observou situação semelhante, ou seja, de um modo geral as instituições não se dedicavam à manutenção dos vínculos familiares e nem realizavam trabalho na tentativa de retornar as crianças e os adolescentes às suas familias de origem.

De acordo com o inciso II, do Art. 92 do ECA, deve-se promover a integração em família substituta, quando esgotados todos os recursos de manutenção na família de origem. Dessa forma, nas situações em que havia impossibilidade da reaproximação com a família, três abrigos estimulavam a adoção e a inserção em família substituta, por meio de contato e envio de relatório para o Juizado. Tal medida contribui, também, para garantir o caráter transitório do abrigo (Art. 101 do ECA, parágrafo único). Por outro lado, quatro entidades não adotavam medidas com essa finalidade. 
No que diz respeito à manutenção dos vínculos entre irmãos, o Art. 92 do ECA, em seu inciso $\mathrm{V}$, recomenda o não desmembramento de grupos de irmãos pelas entidades de abrigo. Desse modo, no caso de encaminhamento de grupos de irmãos, quatro entidades optavam pelo não desmembramento, incentivando a união dos mesmos.

Para KLAUS e col. (2000) e CARVALHO (2000), a manutenção do vínculo afetivo e a proximidade com um membro da família colaboram com o sentimento de confiança e competência do indivíduo, o que é de significativa importância, uma vez que a criança ou adolescente não rompe, de forma brusca e definitiva, os laços familiares.

Mas, por outro lado, um abrigo recebia os irmãos até uma determinada idade, e outro, separava os irmãos pelo sexo, fazendo prevalecer as suas formas de organização, em detrimento do recomendado pelo Estatuto da Criança e do Adolescente. Um abrigo nunca tinha vivenciado esse tipo de situação.

Ainda que previsto no inciso VI, do Art. 92 do ECA, que se deve evitar, sempre que possível, a transferência de crianças e adolescentes para outras entidades de abrigo, cinco responsáveis afirmaram que havia transferências de crianças e adolescentes para outros abrigos, apesar de ser um fato raro de acontecer. Três citaram que o maior motivo de transferência devia-se à idade, mas ocorria, também, por causa de ameaça sofrida por outra criança ou adolescente, pelo fato de a criança não ser soropositiva, por maior identificação com outro abrigo, por incompatibilidade com as regras do abrigo e por retorno ao município de origem. Uma responsável disse que não havia transferência e uma não respondeu.

Em seis abrigos havia, também, o recebimento de crianças e adolescentes de outros abrigos, pelos mesmos motivos já expostos. Uma responsável afirmou que não havia recebimento de crianças e adolescentes de outros abrigos. 
De acordo com KOSMINSKI (1993) e WEBER (1999), as transferências interferem na formação e manutenção de vínculos afetivos, tanto com os trabalhadores, como entre as crianças e adolescentes e, conseqüentemente, trazem prejuízos ao desenvolvimento e à saúde dos institucionalizados.

Para BORGES (1981),.essa realidade pode ser agravada, pelo fato de que crianças que sofrem privação de cuidado materno, por longo tempo, perdem a capacidade de estabelecer relações íntimas e duradouras com outras pessoas.

De acordo com o inciso VII, do Art. 92 do ECA, que incentiva a participação na vida da comunidade local, segundo as responsáveis, todas as entidades realizavam atividades para buscar proximidade com a comunidade. Considerando as diversas possibilidades, cinco entidades participavam de atividades religiosas; cinco delas realizavam festas, cafés, almoços e jantares; duas promoviam apresentações; e uma realizava oficinas de trabalhos manuais.

Segundo REIS (2001), os responsáveis por entidades devem buscar envolver a comunidade, informá-la e conscientizá-la da importância de sua participação no processo de inclusão social de crianças e adolescentes.

Dos 67 entrevistados, 35 (59,3\%) disseram que participavam das atividades desenvolvidas junto à comunidade, enquanto $23(39 \%)$ disseram não participar, e um trabalhador $(1,7 \%)$ não respondeu o questionamento. Em contradição aos colegas de trabalho, oito trabalhadores informaram que não eram desenvolvidas atividades com a comunidade. A incoerência entre as respostas deixa dúvidas quanto à integração com a comunidade.

As sete entidades incentivavam as crianças e adolescentes à prática religiosa, sendo que em seis delas, o incentivo se dava pela presença em missas ou cultos. Em cinco abrigos, o incentivo, também, acontecia pela inclusão nos grupos de catequese e grupos de 
jovens. Uma entidade promovia a leitura bíblica (não foi especificada de qual religião). Em um abrigo, $o$ incentivo era por meio da música.

Segundo as responsáveis, todas as entidades realizavam atividades de cultura e lazer. Os exemplos citados foram: idas a peças de teatro, teatro de fantoches, parques e lanchonetes. Além das saídas, também, recebiam visitas, como, por exemplo, a dos "doutores do riso". As crianças e/ou adolescentes de quatro das entidades praticavam atividades esportivas, fora da entidade.

A participação em atividades de esporte, cultura e lazer funciona como promotora de saúde e importante agente na prevenção de doenças, tanto físicas, como mentais, pois preserva o convívio em sociedade, o que significa inclusão social, e evita o que GOFFMAN (2001) chama de "desculturamento" ou "destreinamento", pelo afastamento da vida em comunidade, o que demandaria tempo de adaptação após o retorno à vida, fora da instituição.

Em relação aos estudos, todas as crianças e adolescentes de quatro abrigos freqüentavam a escola. Dois abrigos que não tinham a totalidade das crianças e adolescentes estudando justificaram problemas de saúde, dificuldade em conseguir vaga nas escolas e pouca idade para estudar à noite. Um abrigo não justificou o motivo.

Na opinião de SOUZA NETO (2002), o fato de freqüentar a escola com as demais crianças e adolescentes permite participar da vida da comunidade e é uma forma de integrálos na sociedade, além de reforçar o espírito de luta para o enfrentamento de desafios.

Pode-se compreender que alguns problemas de saúde, como determinadas patologias neurológicas, impeçam crianças de freqüentar a escola. Porém, os portadores de necessidades especiais devem ser inseridos em escolas, de modo a desenvolver suas habilidades e seu potencial, além de promover a sua inclusão social. Nesta e em todas as demais situações, deve haver empenho no sentido de garantir o direito de acesso à escola, como instituído pela Constituição Federal de 1988. 
Para ADORNO (1999), ter acesso à educação, ao lazer e à cultura é ter a possibilidade de um desenvolvimento saudável, pois a forma como os institucionalizados são tratados, reflete na qualidade e na perspectiva de vida deles. Porém, ressalta que, acontecer o inverso, é uma ameaça não só a eles, mas à sociedade, o que se caracteriza como um problema de saúde pública.

Segundo SANTOS e BASTOS (2002), os adolescentes necessitam, além de lugar seguro, atenção à saúde e educação, de ambientes oportunizadores, ou seja, que possibilitem a sua construção como sujeitos autônomos, com senso de identidade e capacidade de buscar respostas de enfrentamento, além dos recursos institucionais.

Por ser o abrigo em entidade uma medida de caráter provisório, após o período de encaminhamento das questões familiares e/ou juridicas que motivaram a institucionalização, faz-se necessária a preparação para o desligamento, como previsto no Art. 92 do ECA, inciso VIII.

A preparação para o desligamento consiste em uma importante etapa, pois, na maioria dos casos, ao sair do abrigo as crianças ou adolescentes retornam às suas famílias ou são inseridas em famílias substitutas. Na primeira situação, os problemas que levaram à institucionalização poderão estar solucionados ou minimizados, mas existe, também, a possibilidade de voltarem a acontecer, dependendo do fator que os gerou. No caso de inserção em família substituta, há a necessidade de uma fase de adaptação à nova realidade, que poderá acontecer de forma rápida e natural, mas que, também, poderá exigir um grande esforço até que a situação se estabilize. Em ambos os casos, o momento do desligamento é um momento tenso, como todos os momentos de ruptura, e, certamente, carregado de ansiedade e pleno de receios, sonhos e expectativas.

Segundo as responsáveis, a preparação para o dia do desligamento das crianças e adolescentes era realizada por cinco entidades. Em três delas, era realizada pela assistente social. Em uma entidade, era realizada pela psicóloga. Em outra entidade, buscava-se 
inserir os adolescentes no mercado de trabalho, para que pudessem se manter, ao saírem do abrigo. Em uma entidade não havia preparação para o desligamento e, em outra, a responsável não soube informar. Destaca-se que, apesar da relevância do momento do desligamento, uma entidade não tinha a preocupação de fazer a preparação e, mais uma vez, uma gestora desconhecia os procedimentos adotados.

Entre os entrevistados, 66\% (42) disseram que não participavam da preparação para o desligamento e $34 \%$ (22) disseram que participavam (Figura 8). Assim, verificou-se que a preparação para o desligamento, na percepção dos trabalhadores, ia além da citada pelas responsáveis, que focaram a responsabilidade como atribuição das assistentes sociais e psicólogas.

Figura 8: Participação dos entrevistados no programa de preparação para o desligamento das crianças e adolescentes ( $\mathbf{N}=64)$.

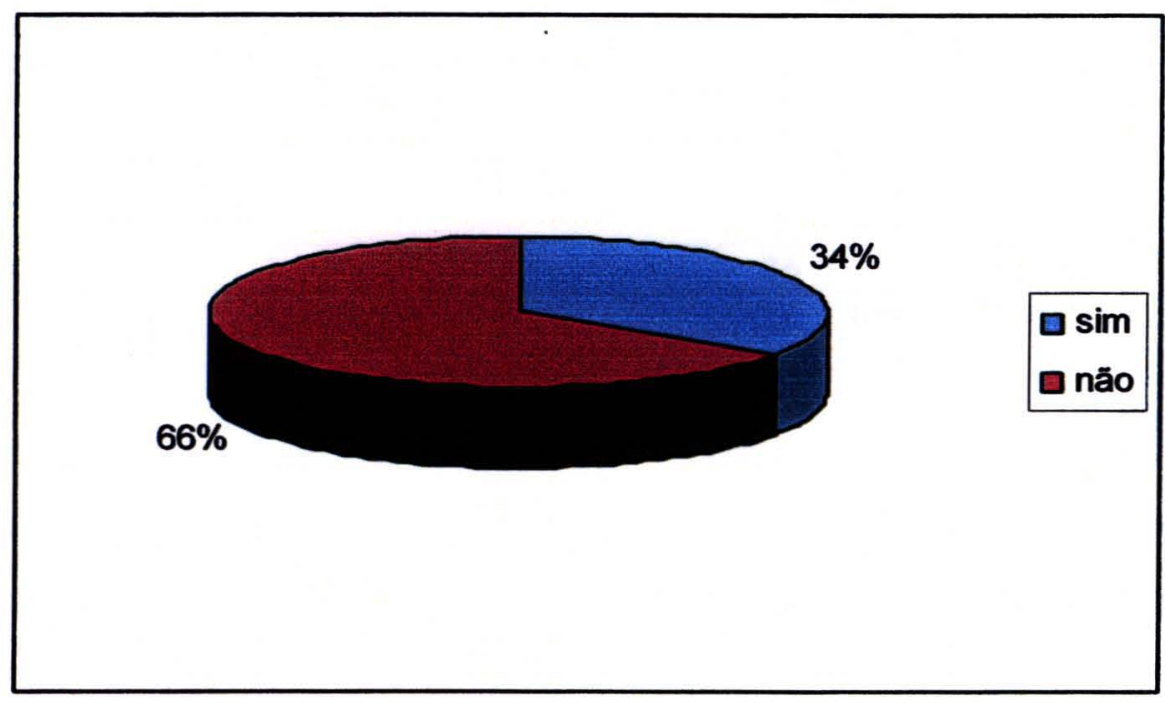

Três trabalhadores de diferentes abrigos informaram que não havia qualquer programa de preparação para o desligamento. Em um abrigo, aproximadamente, metade dos colegas de trabalho disse que participava do desligamento e a outra metade afirmou que não participava. Em outro abrigo, somente um funcionário disse que participava e todos os demais afirmaram que não participavam. Somente em um abrigo todos afirmaram não participar. 
As informações obtidas evidenciaram que, mesmo nos abrigos em que havia o cuidado de se preparar as crianças e adolescentes para o desligamento, não havia a participação da equipe como um todo. No entanto, a preparação para a nova etapa de vida deveria contar, tanto com a atenção especializada das assistentes sociais e psicólogas, como com a de todos os demais trabalhadores que conviveram com a criança ou adolescente durante o período de estada na entidade, principalmente, com a da pessoa com quem teve maior identificação e laço afetivo. Assim, no momento do desligamento, a criança ou adolescente seguiria o seu caminho com maior segurança, por saber que havia alguém que gostava dele e com quem poderia contar, em caso de necessidade.

\section{Tabela 4: Forma de participação dos trabalhadores na preparação para o desligamento das crianças e adolescentes.}

\begin{tabular}{lcc}
\hline Forma de participação & $\mathbf{N}^{\mathbf{o}}$ & $\%$ \\
\hline conversando & 13 & 50,0 \\
preparando para novas realidades & 5 & 19,2 \\
fazendo contato com a família & 2 & 7,7 \\
com festa & 2 & 7,7 \\
não especificada & 4 & 15,4 \\
\hline Total & $\mathbf{2 6}$ & $\mathbf{1 0 0 , 0}$ \\
\hline
\end{tabular}

$\mathrm{Na}$ preparação para o desligamento, a conversa era utilizada em $50 \%$ dos casos. Apenas cinco trabalhadores $(19,2 \%)$ tinham a preocupação de prepará-los para as novas realidades, de modo a serem independentes e estarem preparados para enfrentar, tanto o lugar onde estariam, posteriormente, quanto o mercado de trabalho, no caso dos adolescentes. Dois trabalhadores $(7,7 \%)$ faziam contato com a familia e dois $(7,7 \%)$, faziam festa de despedida. Quatro $(15,4 \%)$ entrevistados não especificaram a forma de atuação (Tabela 4).

Os motivos relatados pelos entrevistados para justificar a falta de participação na preparação para o desligamento das crianças e adolescentes foram os seguintes: dezoito $(42,9 \%)$ consideravam que não era sua atribuição; oito (19\%) disseram que não 
participavam, porque ainda não tinha ocorrido caso de desligamento, no período em que estavam trabalhando no abrigo; quatro $(9,5 \%)$ disseram que não estavam presentes nos momentos do desligamento, por trabalharem em regime de escala, em plantão noturno; três $(7,1 \%)$ alegaram que não eram convidados; três $(7,1 \%)$ não sabiam se havia programa de preparação; e dois $(4,8 \%)$ não se sentiam preparados emocionalmente para participar. Dois trabalhadores (4,8\%) alegaram motivos contraditórios, ou seja, um afirmou que o processo era gradativo e o outro, que não participava, porque era pego de surpresa com a informação do desligamento. Um trabalhador $(2,4 \%)$ disse que deveria haver um programa de preparação e outro $(2,4 \%)$ disse, apenas, que nunca participou, não justificando o motivo.

As justificativas apresentadas reforçaram a necessidade de esclarecimento das equipes, quanto à importância do processo de desligamento e do envolvimento de cada um de seus membros, não só como uma atribuição, mas, principalmente, como uma forma de carinho diante das expectativas geradas nessa fase de vida das crianças e adolescentes.

Ressalta-se que há, também, os que, ao se desligarem da entidade com 18 anos de idade, já possuem independência para buscar construir uma vida própria, fora de seus lares originais. Neste caso, a preocupação quanto à inserção no mercado de trabalho é plausível, pois não há como se manter sem trabalho e a conseqüente remuneração. Porém, nem sempre a remuneração é suficiente para enfrentar despesas como, por exemplo, de moradia. Assim, seria importante que, antes do desligamento, as futuras condições de vida do adolescente jovem fossem checadas, de modo a evitar que ele fosse "obrigado" a se submeter às imposições indesejáveis da vida fora da entidade.

Tão importante quanto verificar as condições de vida que as crianças e os adolescentes deverão enfrentar após o desligamento, é realizar um acompanhamento desses egressos, de forma a observar se os problemas que geraram a institucionalização estão resolvidos, se estão sendo bem tratados, se estão tendo acesso a estudo, se houve adaptação à família substituta, se mantêm o emprego, entre outros. Com esta preocupação, só cinco responsáveis afirmaram que havia acompanhamento dos egressos. 
Das cinco entidades que acompanhavam os egressos, três o faziam por meio de visitas domiciliares e uma ajudava as famílias a se manterem por, aproximadamente, 3 meses. Embora a responsável da outra entidade tenha afirmado que havia o acompanhamento, ela entendia que a competência para tal ação era do Juizado.

Considera-se que o acompanhamento, por meio de visitas e auxílio às famílias, seja importante, porém, não deve acontecer de forma isolada. Melhor seria realizar ações em conjunto, ou seja, as diversas instâncias envolvidas na questão - entidades, organizações, comunidade, governo, poder judiciário e outros - deveriam, de forma organizada e sistemática, colaborar para evitar a reincidência da institucionalização e prevenir a ocorrência de novos casos.

$O$ fato de uma entidade de abrigo compreender que o acompanhamento do egresso cabe ao Juizado, não a exime dessa responsabilidade. Somente delegar não é garantia do cumprimento do dever, pois há o risco da outra parte, também, compreender que não é sua atribuição e o acompanhamento terminar por não ser realizado.

\subsection{Trabalhadores das entidades de abrigo.}

Dos 67 trabalhadores entrevistados, a grande maioria (87\%) pertencia ao sexo feminino (Figura 9). Talvez isso possa ser explicado pelo fato de a maioria das atribuições de uma entidade de abrigo assemelhar-se à de uma casa, com a necessidade de cuidados educacionais e de higiene de crianças e adolescentes, arrumação e limpeza, manutenção de roupas e calçados, realização de refeições, tarefas estas culturalmente atribuídas a pessoas do sexo feminino. 
Figura 9: Número de trabalhadores das entidades de abrigo, por sexo $(\mathrm{N}=67)$.

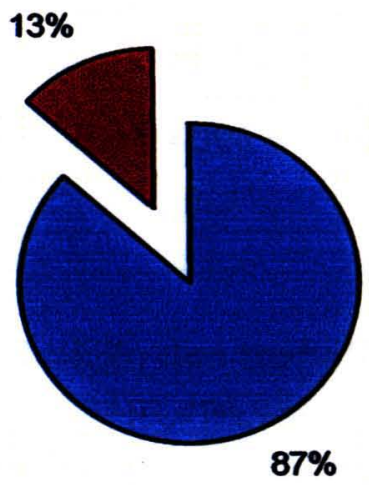

CRIVELLARI e MELO (1989) e LEITE e POSTHUMA (1996) consideram que as características ditas como próprias da mão-de-obra feminina são exigidas e apreciadas, no entanto, por serem avaliadas como “qualidades" e não como qualificação, já que são classificadas como naturais e não como adquiridas em cursos de formação profissional, não trazem às mulheres melhor classificação, nem maior remuneração.

Para BAZON (2001), a constatação de que a maioria dos trabalhadores é do sexo feminino, pode colaborar com a despreocupação em relação a uma formação específica para esse tipo de trabalho, que é considerado como sendo facilmente realizável por mulheres, uma vez que possuem habilidades naturais de cuidar de crianças e de educá-las. Porém, isso ocorre independente das especificidades da demanda, colocando em risco a qualidade do atendimento prestado.

Tabela 5: Distribuição dos trabalhadores dos abrigos, por faixa etária.

\begin{tabular}{lcc}
\hline Faixa etária & $\mathbf{N}^{\circ}$ & $\%$ \\
\hline menos de 20 anos & 1 & 1,5 \\
21 a 30 anos & 24 & 35,8 \\
31 a 40 anos & 14 & 20,9 \\
41 a 50 anos & 20 & 29,9 \\
mais de 50 anos & 8 & 11,9 \\
\hline Total & 67 & 100,0 \\
\hline
\end{tabular}


Em relação à idade dos trabalhadores, a maior freqüência observada foi na faixa etária de 21 a 30 anos (35,8\%), seguida pela faixa etária de 41 a 50 anos (29,9\%) (Tabela 5). O trabalhador mais jovem tinha 18 anos de idade e o que tinha mais idade estava com 57 anos.

Tabela 6: Distribuição dos trabalhadores, segundo a função que exerciam nos abrigos.

\begin{tabular}{lcc}
\hline Função & $\mathbf{N}^{\circ}$ & $\%$ \\
\hline educador (a) & 11 & 16,2 \\
babá & 7 & 10,3 \\
coordenador (a) & 7 & 10,3 \\
cozinheira & 6 & $\mathbf{8 , 8}$ \\
monitor (a) & 6 & 8,8 \\
auxiliar de educação & 5 & 7,4 \\
auxiliar de enfermagem & 5 & 7,4 \\
assistente social & 4 & 5,9 \\
auxiliar de serviços gerais & 4 & 5,9 \\
auxiliar administrativa & 3 & 4,4 \\
lavadeira & 2 & 2,9 \\
motorista & 2 & 2,9 \\
segurança & 2 & 2,9 \\
mãe social & 1 & 1,5 \\
pai social & 1 & 1,5 \\
secretária & 1 & 1,5 \\
supervisor (a) & 1 & 1,5 \\
\hline Total & $\mathbf{6 8}$ & $\mathbf{1 0 0 , 0}$ \\
\hline
\end{tabular}

Ao serem questionados sobre a função que exerciam nos abrigos, os trabalhadores incluíram-se em 17 funções (Tabela 6). Entre os entrevistados, estavam, também, profissionais voluntários, por estarem em atuação nos abrigos no período da coleta de dados. No entanto, nenhum psicólogo ou pedagogo foi entrevistado, embora isto não fosse desejado. 
Observando-se a distribuição dos trabalhadores por categoria, percebeu-se que $42,7 \%(16,2 \%+10,3 \%+8,8 \%+7,4 \%)$ exerciam as funções de educadores, babás, monitores e auxiliares de educação, que, na prática dos abrigos, são funções que realizam atividades similares. Porém, os dados foram apresentados na Tabela 6 de forma separada, para permitir a análise do papel desses trabalhadores junto às crianças e adolescentes.

É possivel que os trabalhadores tenham utilizado nomenclaturas diferentes, apenas porque nos abrigos em que trabalhavam tal denominação fosse usual, sem que ninguém tivesse refletido sobre o significado da palavra e sem que isso interferisse nas suas práticas profissionais. Mas, é possível, também, que a nomenclatura utilizada servisse para expressar, exatamente, o que se compreendia ter como atribuição.

As babás assim se definiram, por dedicarem sua atenção e seus cuidados às crianças mais novas.

No sentido estrito da palavra, educar significa criar condições para formação da inteligência e do espírito; cultivar a inteligência. Já monitorar ou monitorizar significa acompanhar; controlar; observar; fiscalizar; dirigir. Por fim, auxiliar é sinônimo de ajudar.

Na tentativa de definir as três funções, pelas nomenclaturas utilizadas, pode ser que alguns trabalhadores, os educadores, vejam-se como responsáveis pelo desenvolvimento da inteligência e da formação espiritual das crianças e adolescentes, enquanto os auxiliares de educação entendam-se como ajudantes dos primeiros, o que faz diminuir a sua responsabilidade. Por outro lado, existe a possibilidade de os monitores considerarem que devem agir de forma mais distante, atuando como observadores e controladores das situações.

Para BAZON e BIASOLI-ALVES (2000a), os monitores são, na sua essência, educadores, e assim devem ser, para que não sejam reproduzidos modelos que não 
obtiveram sucesso no passado. Indo além da função, todos os trabalhadores das entidades de abrigo, pelo contexto em que estão inseridos, devem ter a responsabilidade de educar.

De acordo com SOUZA NETO (2002), agindo dessa forma, os trabalhadores poderão promover o desenvolvimento saudável e integral dos institucionalizados, além de colaborar com a superação de seus problemas, estimulando-os a irem em busca de um novo projeto de vida, e incentivá-los em direção à autonomia e independência.

Complementando, BAZON (2001) diz que o desenvolvimento humano ocorre, simultaneamente, nos planos afetivo, cognitivo, social e psicomotor, e cabe à ação educativa mediar a interação entre o indivíduo e o meio, de forma a desenvolver todo o seu potencial.

Nas entidades de abrigo, cada trabalhador tem uma importante missão a cumprir, e o grupo em si, também, mas evidencia-se a responsabilidade e a fundamental atuação dos educadores, por serem as pessoas que têm contato mais próximo com as crianças e adolescentes, fornecendo-lhes proteção e cuidados, atuando no papel de "mãe substituta", inclusive com o estabelecimento de vínculos afetivos.

Outra informação relevante é que, embora cinco trabalhadores tenham se definido como auxiliares de enfermagem, dois deles não tinham formação na área, mas eram responsáveis por ações de saúde.

Tabela 7: Tempo de exercício da função nos abrigos.

\begin{tabular}{lcc}
\hline Tempo de exercício da função & $\mathbf{N}^{\circ}$ & $\%$ \\
\hline de 0 meses a 1 ano & 33 & 49,2 \\
de 1 ano a 2 anos & 17 & 25,4 \\
de 2 anos a 3 anos & 6 & 8,9 \\
de 3 anos a 4 anos & 3 & 4,5 \\
de 4 anos a 5 anos & 4 & $\mathbf{6 , 0}$ \\
acima de 5 anos & 3 & $\mathbf{6 , 0}$ \\
\hline Total & $\mathbf{6 7}$ & $\mathbf{1 0 0 , 0}$ \\
\hline
\end{tabular}


De acordo com a Tabela 7 , aproximadamente, metade $(49,2 \%)$ dos trabalhadores estava no exercício de suas respectivas funções há, no máximo, um ano. Um quarto dos trabalhadores $(25,4 \%)$ estava na função por um período entre um e dois anos. Assim, três quartos dos trabalhadores estavam no exercício de suas funções há, no máximo, dois anos, situação esta semelhante à observada quando analisado o tempo de exercício na função de responsáveis pelos abrigos. Somente três $(6,0 \%)$ trabalhadores estavam na função há mais de cinco anos.

Os dados sugerem duas reflexões: a primeira é sobre a qualidade da atenção prestada às crianças e adolescentes, já que a grande maioria dos trabalhadores contava com experiência de menos de dois anos em sua função e, a segunda, é que o elevado número de trabalhadores, relativamente novos, indica uma alta rotatividade dos mesmos.

KOSMINSKI (1993), WEBER (1999) e CARVALHO (2000) avaliam a rotatividade dos trabalhadores dos abrigos como um importante fator de interferência na formação de vínculos afetivos, por parte das crianças e adolescentes, que, assim como as transferências de uma entidade para outra, reflete na formação de relações sociais duradouras.

BAZON (2001) diz que a alta rotatividade pode ser decorrência da insatisfação ou da sensação de inadequação profissional, gerada pela falta de formação para atuar no campo da assistência social. 
Tabela 8: Atividades desenvolvidas pelos trabalhadores nos abrigos.

\begin{tabular}{|c|c|c|}
\hline Atividade desenvolvida & $\mathbf{N}^{\mathbf{0}}$ & $\%$ \\
\hline $\begin{array}{l}\text { exclusivamente cuidado pessoal com as crianças/adolescentes (higiene, } \\
\text { medicamentos) }\end{array}$ & 18 & 17,8 \\
\hline \multicolumn{3}{|l|}{ acompanhamento externo/motorista (levar a médico, escola, outro lugar) } \\
\hline & 12 & 11,9 \\
\hline apoio às atividades escolares & 12 & 11,9 \\
\hline atividades domésticas e cuidado com as crianças/adolescentes & 12 & 11,9 \\
\hline atividades lúdicas / físicas / profissionalizantes & 11 & 10,9 \\
\hline $\begin{array}{l}\text { exclusivamente atividades domésticas (limpeza, cozinha, roupas, } \\
\text { manutenção) }\end{array}$ & 11 & 10,9 \\
\hline \multicolumn{3}{|l|}{ serviços administrativos (coordenação, supervisão, atividades financeiras) } \\
\hline & 11 & 10,9 \\
\hline orientação (conversa, conselho, boas maneiras, disciplina, religiosa) & 8 & 7,9 \\
\hline atividades técnicas especializadas & 4 & 3,9 \\
\hline segurança & 2 & 2,0 \\
\hline Total & 101 & 100,0 \\
\hline
\end{tabular}

Das atividades realizadas pelos entrevistados, a maioria (60,4\%) estava relacionada à atenção direta às crianças e adolescentes, incluindo cuidados pessoais, controle de medicamentos, acompanhamento nas atividades externas ao abrigo, apoio nas atividades escolares, realização de atividades lúdicas, fisicas e profissionalizantes, além de conversas para orientação sobre boas maneiras, religião, entre outros. Outros trabalhadores $(11,9 \%)$ tinham que conciliar os afazeres domésticos no abrigo com os cuidados das crianças e adolescentes, enquanto 10,9\% dedicavam-se, exclusivamente, às atividades domésticas, como cozinhar, lavar e passar roupa, limpar a casa (Tabela 8). 
As responsabilidades administrativas cabiam a $10,9 \%$ dos trabalhadores e as atividades técnicas na área social a 3,9\% deles. Dois (2\%) trabalhadores realizavam a segurança de um dos abrigos (Tabela 8).

Questionou-se se as crianças e adolescentes auxiliavam na execução das tarefas diárias dos abrigos e 69\% (46) dos entrevistados afirmaram que havia participação deles, enquanto os demais $31 \%$ (21) afirmaram o contrário. Observou-se, no entanto, que a resposta de dez trabalhadores, que negaram a participação das crianças e adolescentes, foi incoerente com a informação dada pelos demais colegas de trabalho, talvez por receio de que a execução de atividades domésticas, por parte dos institucionalizados, contrariasse alguma regra ou legislação. Porém, em termos educacionais, é importante que os indivíduos possam colaborar nas atividades diárias, de modo que, gradativamente, sejam preparados para a vida, adquirindo noções de cooperação, organização, higiene e limpeza, e sintam-se parte do grupo, realizando pequenas tarefas, como na vida em família.

\section{Figura 10: Participação das crianças e adolescentes na execução das tarefas diárias do abrigo, segundo depoimento dos entrevistados $(\mathbf{N}=67)$.}

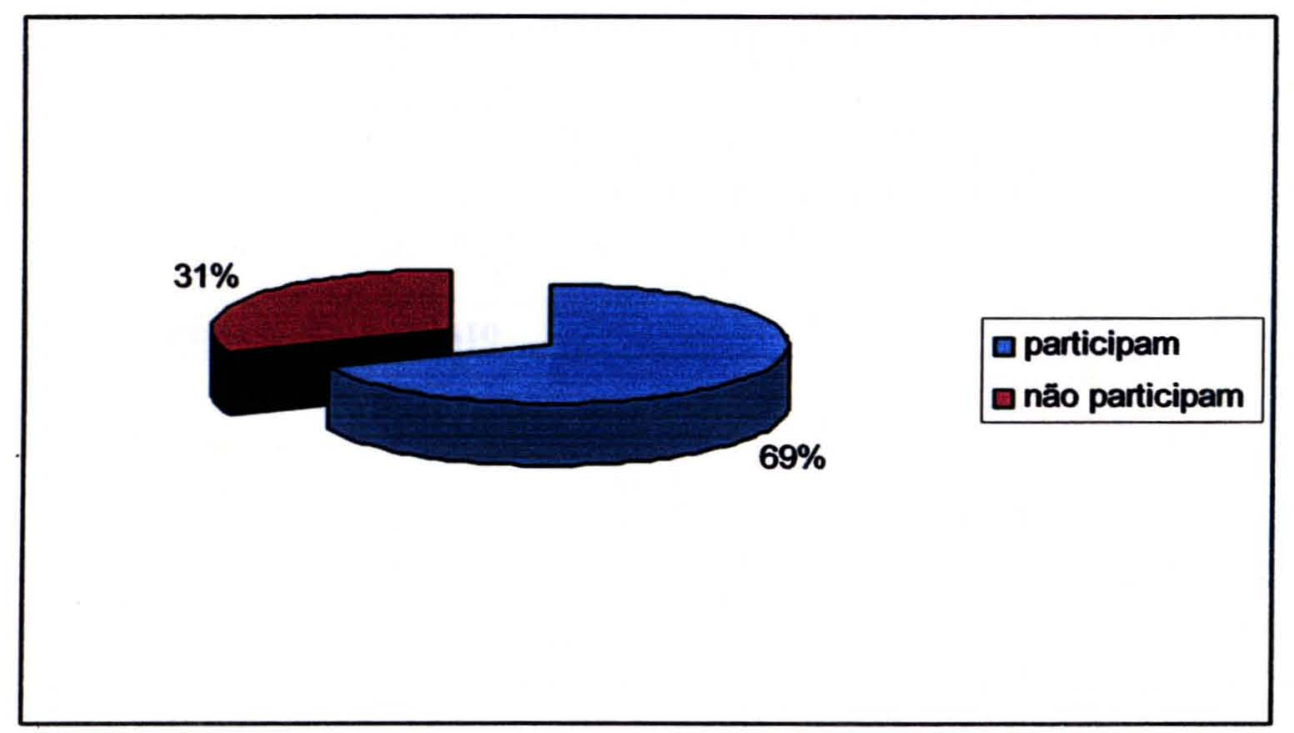

Os 46 trabalhadores que afirmaram a participação das crianças e adolescentes nas tarefas diárias do abrigo (Figura 10) disseram que havia uma predominância nas atividades de organização, arrumação e limpeza da casa $(72,1 \%)$ e que, em menor escala, eles 
auxiliavam nas atividades de cozinha $(8,8 \%)$ e cuidavam das roupas e calçados $(8,8 \%)$ (Tabela 9).

Tabela 9: Formas de participação das crianças e adolescentes na execução das tarefas diárias do abrigo.

\begin{tabular}{lcc}
\hline $\begin{array}{l}\text { Formas de participação na execução das tarefas } \\
\text { diárias do abrigo }\end{array}$ & $\mathbf{N}^{\circ}$ & $\%$ \\
\hline organização / arrumação da casa & 29 & 42,7 \\
limpeza da casa & 20 & 29,4 \\
participam de forma não especificada & 7 & 10,3 \\
auxílio nas atividades de cozinha & 6 & $\mathbf{8 , 8}$ \\
cuidado com as roupas, calçados (lavar / passar) & 6 & $\mathbf{8 , 8}$ \\
\hline Total & $\mathbf{6 8}$ & $\mathbf{1 0 0 , 0}$ \\
\hline
\end{tabular}

Em função da carga horária e do regime de trabalho dos profissionais, observou-se uma variação da freqüência de contato e do tempo de permanência deles com as crianças e adolescentes. Havia profissionais que trabalhavam diariamente no abrigo, mas com cargas horárias variadas, e outros que trabalhavam em regime de escala (12/24h ou 12/36h). Havia, também, os que trabalhavam em dias fixos da semana, variando entre um contato semanal e um contato mensal.

Tabela 10: Freqüência com que os trabalhadores tinham contato com as crianças e adolescentes.

\begin{tabular}{lcc}
\hline Freqüência de contato & $\mathbf{N}^{\mathbf{0}}$ & $\%$ \\
\hline diário & 22 & 33,3 \\
1 dia / semana & 1 & 1,5 \\
2 a 4 dias / semana & 42 & 63,7 \\
1 dia / mês & 1 & 1,5 \\
\hline Total & $\mathbf{6 6}$ & $\mathbf{1 0 0 , 0}$ \\
\hline
\end{tabular}

$\mathrm{Na}$ tabela 10 , é possível se verificar que dois terços $(66,7 \%)$ dos trabalhadores não tinham contato diário com as crianças e adolescentes e que um terço $(33,3 \%)$ deles tinha contato diário. Apenas um trabalhador não tinha qualquer contato com as crianças e adolescentes, por atuar em atividade administrativa. 
O fato de a grande maioria dos trabalhadores não ter contato diário com as crianças e adolescentes pode ser mais um fator de interferência na formação de vínculos afetivos entre as partes, embora, possivelmente, mais importante que o tempo de contato, deve ser a qualidade da relação interpessoal vivenciada. Mas, de qualquer forma, as características da relação diferenciam bem a vida da criança e adolescente institucionalizados, da vida passada em família.

Para BORGES (1981), o regime monótono de cuidados, o isolamento dos acontecimentos diários e a variedade de pessoas que prestam os cuidados geram transtornos comportamentais na criança, assim como retardam o seu desenvolvimento físico e mental. Deve-se, então, valorizar a continuidade e a estabilidade do relacionamento entre o adulto responsável e a criança ou adolescente.

\section{Figura 11: Número de entrevistados, por situação trabalhista} $(\mathrm{N}=67)$.

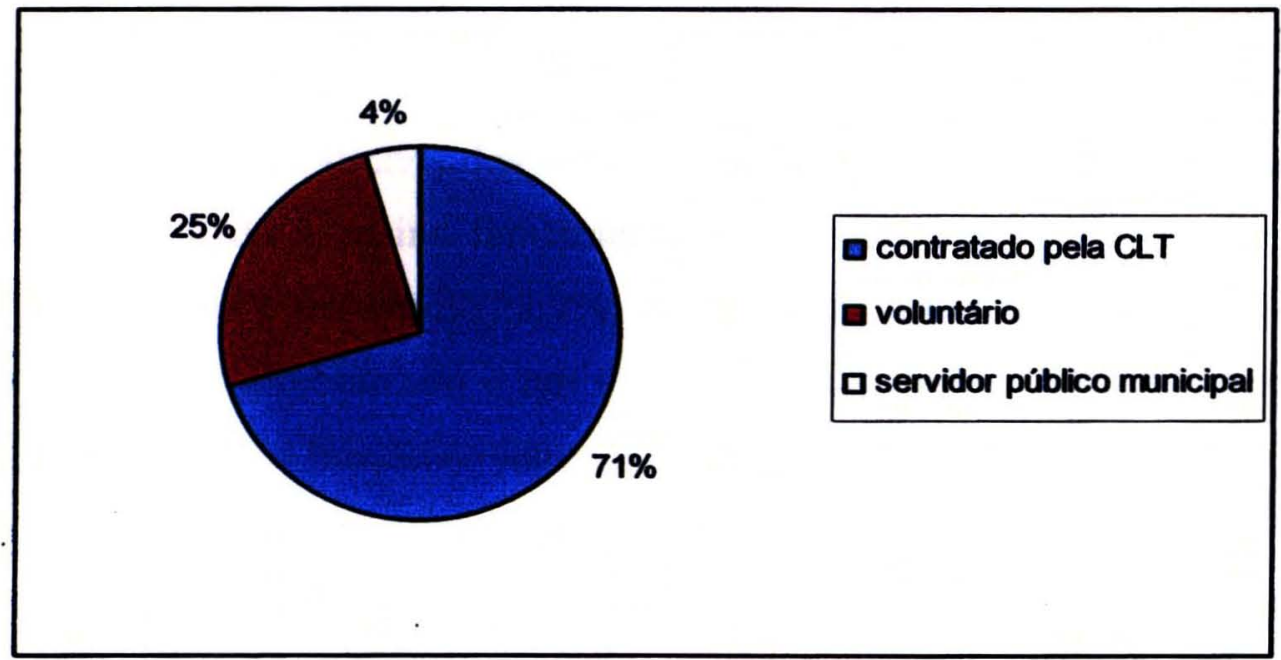

Com referência à situação trabalhista dos funcionários, verificou-se que a maioria (71\%) trabalhava em regime de contrato e $25 \%$ deles atuavam como voluntários. Somente três (4\%) funcionários eram servidores públicos municipais (Figura 11). 
Vale ressaltar que alguns voluntários informaram receber ajuda de custo. Porém, o trabalho voluntário caracteriza-se em fazer algo por vontade própria. A partir do momento em que há uma remuneração pela tarefa realizada, ele já está descaracterizado. Talvez o fato de manter trabalhadores na situação de voluntariado, mas oferecer a eles remuneração, seja uma forma mais econômica, porém é, assim mesmo, injusta e irregular frente à legislação trabalhista.

Tabela 11: Grau de instrução dos entrevistados.

\begin{tabular}{lcc}
\hline Grau de instrução & $\mathbf{N}^{\circ}$ & $\%$ \\
\hline somente assinava o nome & 1 & 1,5 \\
alfabetizado (lia e escrevia) & 1 & 1,5 \\
ensino fundamental $\left(1^{\mathrm{a}}\right.$ a $4^{\mathrm{a}}$ série) & 6 & $\mathbf{8 , 9}$ \\
ensino fundamental $\left(5^{\mathrm{a}}\right.$ a $\mathbf{8}^{\mathrm{a}}$ série) & 16 & 23,9 \\
ensino médio & 33 & 49,2 \\
superior incompleto & 4 & $\mathbf{6 , 0}$ \\
superior completo & 4 & $\mathbf{6 , 0}$ \\
pós-graduação lato-sensu & 2 & 3,0 \\
\hline Total & $\mathbf{6 7}$ & $\mathbf{1 0 0 , 0}$ \\
\hline
\end{tabular}

Ao se levantar o grau de instrução dos trabalhadores, observou-se que aproximadamente a metade $(49,2 \%)$ dos funcionários havia freqüentado o ensino médio e $32,8 \%$ haviam freqüentado o ensino fundamental, sendo que seis $(8,9 \%)$ haviam cursado somente as séries iniciais e dezesseis $(23,9 \%)$ haviam cursado as séries finais. Um $(1,5 \%)$ funcionário declarou ser alfabetizado e um $(1,5 \%)$ afirmou saber apenas assinar o nome, sendo que ambos exerciam a função de segurança (Tabela 11).

Quatro funcionários (6\%) tinham iniciado curso superior, mas não haviam concluído (Tabela 11). Os cursos freqüentados foram: administração, serviço social e teologia. Um não especificou o curso.

Seis $(9 \%)$ trabalhadores eram graduados, sendo que dois (3\%) deles tinham freqüentaram curso de pós-graduação lato-sensu (Tabela 11). Os cursos de graduação freqüentados foram: serviço social, em quatro casos; pedagogia, em um caso; e 
administração, em outro caso. Os cursos de pós-graduação foram: Políticas e Práticas Sociais em Saúde; e Sexologia.

Os cursos de graduação e de pós-graduação freqüentados pelos profissionais mostram-se pertinentes com a área de atuação. Muito embora, seja alto o número de trabalhadores sem formação adequada para atuar na área.

Tabela 12: Cursos frequientados pelos trabalhadores.

\begin{tabular}{lcc}
\hline Curso freqüentado & $\mathbf{N}^{\mathbf{0}}$ & $\%$ \\
\hline de informática & 22 & 22,0 \\
de língua estrangeira & 6 & 6,0 \\
outros & 50 & 50,0 \\
nenhum & 22 & 22,0 \\
\hline Total & $\mathbf{1 0 0}$ & $\mathbf{1 0 0 , 0}$ \\
\hline & & (múltipla escolha)
\end{tabular}

Além dos estudos regulares, vinte e dois trabalhadores tinham freqüentado curso de informática e seis tinham cursado alguma língua estrangeira. Vinte e dois trabalhadores nunca freqüentaram qualquer curso, o que confirma o fato de que não possuíam formação específica para o exercício de suas funções (Tabela 12).

Para que as entidades de abrigo atinjam os objetivos a que se propõem, faz-se necessário que os trabalhadores em exercício possuam qualificação no campo de atuação, pois as suas ações refletem diretamente no desenvolvimento de crianças e adolescentes com histórias de vida já muito complexas e marcadas por fatos negativos. Cabe a cada trabalhador contribuir, de forma positiva, para a melhoria da qualidade de vida dos institucionalizados, não bastando somente boa vontade, embora esta virtude também seja de fundamental importância.

Alguns trabalhadores freqüentaram cursos mais relacionados ao campo de atuação. Os cursos foram organizados por área e constam no Quadro 7: 
Quadro 7: Outros cursos freqüentados pelos trabalhadores dos abrigos.

\begin{tabular}{|c|c|c|}
\hline Área & Curso freqüentado & $\mathbf{N}^{\circ}$ \\
\hline \multirow[t]{5}{*}{ Educação } & capacitação de educadores & 5 \\
\hline & atendente de creche & 3 \\
\hline & magistério & 2 \\
\hline & matemática & 1 \\
\hline & pedagogia & 1 \\
\hline \multirow[t]{7}{*}{ Saúde } & primeiros socorros & 3 \\
\hline & auxiliar técnico de laboratório de análises clínicas & 2 \\
\hline & berçarista & 2 \\
\hline & técnico de enfermagem & 2 \\
\hline & auxiliar de enfermagem & 1 \\
\hline & medicina esportiva & 1 \\
\hline & sexualidade e drogas & 1 \\
\hline \multirow[t]{3}{*}{ Administrativa } & datilografia & 3 \\
\hline & técnico de secretariado & 3 \\
\hline & telefonista/recepcionista & 1 \\
\hline \multirow[t]{3}{*}{ Prestação de serviço } & telemarketing & 2 \\
\hline & garçonete & 1 \\
\hline & vendas & 1 \\
\hline \multirow[t]{3}{*}{ Psicologia } & lidar com falecimento & 1 \\
\hline & psicologia etransdisciplinar & 1 \\
\hline & relações humanas & 1 \\
\hline Artes & artesanato & 2 \\
\hline \multirow[t]{2}{*}{ Gestão } & gerenciamento & 1 \\
\hline & gestão hospitalar & 1 \\
\hline Alimentos & culinária & 1 \\
\hline Economia & contabilidade & 1 \\
\hline Não especificada & não especificado & 6 \\
\hline Total & & $\mathbf{5 0}$ \\
\hline
\end{tabular}

Observa-se que, além da formação escolar, doze trabalhadores freqüentaram cursos na área de educação, doze freqüentaram cursos na área de saúde e três, na área de 
psicologia (Quadro 7). Conhecimentos nessas três áreas, não minimizando as demais, são fundamentais para a promoção de saúde e desenvolvimento pessoal e intelectual das crianças e adolescentes. Porém, apesar de conhecimentos na área social serem fundamentais para quem atua em entidades de abrigo, percebe-se que nenhum trabalhador aprofundou seus estudos nesse campo.

Sete trabalhadores participaram de cursos na área administrativa, dois, na área de gerenciamento e um freqüentou curso de contabilidade (Quadro 7). Esses conhecimentos podem colaborar na parte gerencial, administrativa e econômica das entidades.

Dois entrevistados fizeram curso de artesanato, o que possibilita trabalhar a criatividade e a habilidade motora das crianças e adolescentes, entre outros aspectos. Outro trabalhador fez curso de culinária; conhecimento que, se bem aplicado, também, pode colaborar com a saúde dos institucionalizados (Quadro 7).

Embora a quantidade de cursos realizados possa sugerir que os trabalhadores estavam qualificados para o exercício de suas funções, a quantidade de curso por área é pequena, ainda mais se for considerado que os trabalhadores estavam atuando em sete diferentes entidades. Além disso, os temas dos cursos sugerem que eles aconteceram de forma isolada, não havendo um programa de qualificação permanente (assunto tratado no item 7.4.3.).

\subsubsection{Informações sobre saúde.}

Ao serem questionados sobre o que entendiam por saúde, trinta e seis $(37,5 \%)$ responderam que ter saúde era estar bem fisicamente, ressaltando a importância da alimentação, da higiene, da atividade física e do sono. Dezenove $(19,8 \%)$ entendiam que saúde era o bem-estar emocional e psíquico, chamando a atenção para o sentimento de felicidade. Dezenove $(19,8 \%)$ definiram saúde como a prioridade na vida, o mais importante de tudo. Onze $(11,5 \%)$ disseram que saúde era a ausência de doença, era não sentir nada (Tabela 13). 
Outras definições foram citadas, como bem-estar social $(5,2 \%)$, com ênfase para o meio ambiente, a moradia, o acesso à assistência médica; bem-estar cultural $(3,1 \%)$, com destaque para o bom desenvolvimento escolar; e bem-estar espiritual $(3,1 \%)$ (Tabela 13$)$.

Tabela 13: Significado de saúde para os entrevistados.

\begin{tabular}{lcc}
\hline Saúde é: & $\mathbf{N}^{\circ}$ & $\%$ \\
\hline bem-estar físico & 36 & 37,5 \\
bem-estar emocional / psíquico & 19 & 19,8 \\
o mais importante na vida & 19 & 19,8 \\
ausência de doença & 11 & 11,5 \\
bem-estar social & 5 & 5,2 \\
bem-estar cultural & 3 & 3,1 \\
bem-estar espiritual & 3 & 3,1 \\
\hline Total & $\mathbf{9 6}$ & $\mathbf{1 0 0 , 0}$ \\
\hline & \multicolumn{3}{c}{ (múltipla escolha) }
\end{tabular}

Embora alguns trabalhadores tenham citado mais de um aspecto relacionado a bemestar para definir saúde, nenhum deles citou a difundida definição de saúde da Organização Mundial de Saúde, de 1945, como sendo bem-estar físico, mental e social, e não apenas ausência de doença, e nem o conceito mais moderno da $8^{a}$ Conferência de Saúde de 1986, que fala do atendimento às necessidades individuais e coletivas e focaliza a saúde como resultante de condições de vida (PELICIONI 2000; SEBASTIANI 2004).

Tabela 14: Principais queixas das crianças e adolescentes em relação à saúde física.

\begin{tabular}{lcc}
\hline Principais queixas & $\mathbf{N}^{\circ}$ & $\%$ \\
\hline cefaléia & 22 & 26,5 \\
problemas do aparelho gastrintestinal & 21 & 25,3 \\
problemas do aparelho respiratório/ otorrinolaringológicos & 17 & 20,5 \\
problemas odontológicos & 6 & 7,2 \\
problemas dermatológicos & 5 & 6,1 \\
cólicas menstruais & 3 & 3,6 \\
outros & 6 & 7,2 \\
não sabe & 2 & 2,4 \\
não respondeu & 1 & 1,2 \\
\hline Total & $\mathbf{8 3}$ & $\mathbf{1 0 0 , 0}$ \\
\hline & & (múltipla escolha)
\end{tabular}


As queixas mais freqüentes das crianças e adolescentes em relação à saúde física eram: cefaléia (26,5\%); problemas do aparelho gastrintestinal (25,3\%), principalmente, "dor de barriga", gases, prisão de ventre e verminose; problemas do aparelho respiratório/otorrinolaringológicos $(20,5 \%)$, com ênfase para gripe, sinusite, dor de ouvido e de garganta; problemas odontológicos (7,2\%); problemas dermatológicos (6,1\%); e cólicas menstruais $(3,6 \%)$ (Tabela 14).

Dois trabalhadores não souberam informar as queixas por não terem contato direto com as crianças e adolescentes e quinze afirmaram que eles não faziam queixas relacionadas à questão da saúde física.

Tabela 15: Principais queixas das crianças e adolescentes em relação às questões afetivas.

\begin{tabular}{lcc}
\hline Principais queixas & $\mathbf{N}^{\circ}$ & $\%$ \\
\hline falta/saudade de um lar/família & 36 & $\mathbf{6 0 , 0}$ \\
necessidade de atenção e carinho & 9 & 15,0 \\
ciúmes & 3 & 5,0 \\
problemas da familiares & 3 & 5,0 \\
saudade dos funcionários que saíram & 1 & 1,7 \\
outros & 3 & 5,0 \\
não sabe & 2 & 3,3 \\
não respondeu & 3 & 5,0 \\
\hline Total & $\mathbf{6 0}$ & $\mathbf{1 0 0 , 0}$ \\
\hline & & (múltipla escolha)
\end{tabular}

Em relação às questões afetivas, a principal queixa era a falta do lar e/ou da família (60\%), sobretudo da mãe ou do pai, surgindo, por alguns, o desejo de adoção (Tabela 15). No entanto, segundo DIAS (1992) e WEBER (1995), embora muitas pessoas desejem adotar e muitas crianças sonhem com uma família substituta, existem entraves, como o preconceito. Somam-se a isso as questões jurídicas e burocráticas.

Ocorria, também, a solicitação de atenção e carinho (15\%), os ciúmes (5\%), relato dos problemas familiares (5\%) e a saudade dos funcionários que já não trabalhavam mais no abrigo (1,7\%) (Tabela 15), o que é coerente com a literatura. 
BORGES (1981), KOSMINSKI (1993) e MARTINS NETO (2001) relatam evidências de maior necessidade de afeto apresentada por crianças e adolescentes institucionalizados.

Dois trabalhadores não souberam informar sobre as queixas afetivas e dezesseis entrevistados disseram que não havia esse tipo de queixa.

$O$ relato de ausência de queixas leva a algumas reflexões: talvez as queixas fossem dirigidas a alguns trabalhadores e não a outros, por repressão, por maior ou menor receptividade/disponibilidade; ou talvez as queixas não ocorressem, por falta de referencial por parte das crianças e adolescentes, por não saberem a quem recorrer em caso de necessidades específicas; e ainda, é possível que as queixas ocorressem e fossem desvalorizadas, e, então, era como se não acontecessem. Em qualquer uma dessas hipóteses, a falta de atenção às questões afetivas pode deixar marcas nas crianças e adolescentes e os reflexos tornar-se-ão evidentes ao longo de suas vidas.

Tabela 16: Postura dos trabalhadores diante dos problemas relatados pelas crianças e adolescentes.

\begin{tabular}{lcc}
\hline Postura diante dos problemas relatados & $\mathbf{N}^{\mathbf{o}}$ & $\%$ \\
\hline escutava/ conversava/ orientava & 33 & 44,6 \\
dava medicação & 11 & 14,9 \\
encaminhava para outro trabalhador & 8 & 10,8 \\
procurava a veracidade da queixa & 6 & $\mathbf{8 , 1}$ \\
dava carinho & 5 & 6,8 \\
nada fazia & 4 & 5,4 \\
outros & 3 & 4,0 \\
não respondeu & 4 & 5,4 \\
\hline Total & $\mathbf{7 4}$ & $\mathbf{1 0 0 , 0}$ \\
\hline & & \multicolumn{2}{c}{ (múltipla escolha) }
\end{tabular}

Diante das queixas das crianças e adolescentes, trinta e três $(44,6 \%)$ trabalhadores optavam por escutar o problema, conversar e orientar. 
SOUZA NETO (2002) diz que diálogo e orientações geram bem-estar físico e emocional, estimulam a amizade e a confiança, que são subsídios capacitadores para o enfrentamento de problemas .

Onze (14,9\%) entrevistados administravam medicação, no caso de queixas físicas, e, em alguns casos, davam água com açúcar, fazendo de conta que era remédio. Oito $(10,8 \%)$ encaminhavam para outro trabalhador, mais comumente para a coordenadora, auxiliar de enfermagem ou assistente social. Seis $(8,1 \%)$ buscavam verificar se a queixa era verídica, normalmente, desviando a atenção para observar se a queixa se repetia. Cinco $(6,8 \%)$ entrevistados afirmaram que davam carinho (Tabela 16).

Quatro $(5,4 \%)$ funcionários nada faziam, por considerar que não era atribuição deles (Tabela 16); julgavam ser competência de outro trabalhador. No entanto, em entidades de abrigo, todos devem ter uma postura de contribuição para o bom desenvolvimento das crianças e adolescentes e para o estabelecimento de relações interpessoais positivas, de modo a prepará-los para a vida em sociedade.

Três trabalhadores disseram que tomavam atitude firme e otimista diante dos relatos das crianças e adolescentes, sem especificá-las, e quatro confirmaram a posição de que não havia queixas. 
Tabela 17: Problemas de saúde que as crianças e adolescentes mais apresentavam, na opinião dos entrevistados.

\begin{tabular}{lcc}
\hline Problemas de saúde que mais apresentavam & $\mathbf{N}^{\circ}$ & $\%$ \\
\hline problemas do aparelho respiratório/ otorrinolaringológicos & 41 & $\mathbf{3 8 , 0}$ \\
problemas do aparelho gastrintestinal & 17 & 15,7 \\
problemas dermatológicos & 14 & 13,0 \\
problemas psicológicos/psiquiátricos/neurológicos & 7 & $\mathbf{6 , 5}$ \\
cefaléia & 6 & 5,5 \\
problemas odontológicos & 4 & 3,7 \\
cólicas menstruais & 2 & 1,9 \\
problemas cardíacos & 1 & 0,9 \\
outros & 13 & 12,0 \\
não sabe & 1 & $\mathbf{0 , 9}$ \\
não respondeu & 2 & $\mathbf{1 , 9}$ \\
\hline Total & $\mathbf{1 0 8}$ & $\mathbf{1 0 0 , 0 0}$ \\
\hline
\end{tabular}

$\mathrm{Na}$ observação dos trabalhadores, os problemas de saúde que as crianças e adolescentes mais apresentavam estavam relacionados ao aparelho respiratório (38\%), entre eles, gripe, congestão nasal, tosse, dor de garganta e de ouvido, bronquite e pneumonia (Tabela 17).

A segunda maior freqüência estava relacionada a problemas do aparelho gastrintestinal (15,7\%), incluindo "dor de barriga", diarréia, prisão de ventre e verminose. Em seguida, os problemas dermatológicos (13\%): coceira, micose, furúnculo, dermatite atópica, sarna, entre outros (Tabela 17).

Entre os problemas de saúde apresentados estavam, também, os psicológicos/psiquiátricos/neurológicos (6,5\%), como depressão, disritmia, autismo, esquizofrenia, neuropatias, hidrocefalia, entre outros; a cefaléia (5,5\%); os problemas odontológicos $(3,7 \%)$; as cólicas menstruais $(1,9 \%)$ e os problemas cardíacos $(0,9 \%)$. Outros problemas citados foram: febre, cansaço, desnutrição e dores não especificadas (Tabela 17). 
Quatro trabalhadores disseram que não havia problemas de saúde, o que é incoerente com a realidade humana, sujeita a inúmeros fatores que podem desencadear doenças. Talvez a postura tenha sido uma tentativa exagerada de mostrar que as crianças e adolescentes eram bem cuidados.

Tabela 18: Formas de contribuição para a manutenção da saúde das crianças e adolescentes, na opinião dos trabalhadores.

\begin{tabular}{lcc}
\hline Formas de contribuição para a manutenção da saúde & $\mathbf{N}^{\circ}$ & $\%$ \\
\hline orientação / educação / cuidados pessoais & 54 & 65,1 \\
encaminhando para profissionais ou serviços especializados & 12 & 4,5 \\
dando amor / carinho / apoio emocional & 11 & 3,2 \\
realizando ou incentivando atividades físicas, lúdicas e de lazer & 2 & 2,4 \\
outros & 3 & 3,6 \\
não respondeu & 1 & 1,2 \\
\hline Total & $\mathbf{8 3}$ & $\mathbf{1 0 0 , 0}$ \\
\hline & & (múltipla escolha)
\end{tabular}

$\mathrm{Na}$ opinião dos trabalhadores, a maior forma de contribuição deles para a manutenção e proteção da saúde das crianças e adolescentes se dava por meio da orientação, da educação e dos cuidados pessoais - alimentação, higiene, vestuário adequado, medicação $(65,1 \%)$ (Tabela 18$)$.

Outras formas de contribuição eram: encaminhar para profissionais ou serviços especializados (4,5\%); dar amor, carinho, atenção e apoio emocional $(3,2 \%)$; realizar ou incentivar atividades físicas, lúdicas e de lazer $(2,4 \%)$ (Tabela 18$)$.

SOUZA NETO (2002) considera que o amor é o fundamento para a superação das frustrações. Interiorizar e exteriorizar a experiência amorosa ajudam a criança e o adolescente a transformar as frustrações em novos sonhos, construir um projeto de vida e conquistar a cidadania.

É importante observar que os trabalhadores valorizaram muitas ações relevantes para a promoção da saúde, como educação, orientação, atenção, carinho, atividades lúdicas 
e de lazer, entre outras, e não, somente, as de cunho assistencialistas, como consultas e medicações, e as de atendimento a necessidades biológicas, como higiene e alimentação.

Quatro trabalhadores entendiam que não contribuiam para a saúde das crianças e adolescentes, por não fazer parte das suas atribuições ou por não ter contato com eles. No entanto, colaborar com a promoção da saúde dos institucionalizados é dever de todos os envolvidos na dinâmica dos abrigos, mesmo que não seja uma atribuição direta ou contratual, inclusive porque, medidas aparentemente simples, como um momento de atenção, caracterizam-se como promotoras de saúde. É possível, também, que esses trabalhadores colaborassem neste sentido, mas, talvez, pelo conceito que tinham do que era saúde, não percebessem o valor de suas ações.

\subsubsection{Informações sobre o trabalho desenvolvido nos abrigos.}

Foi solicitado aos entrevistados que avaliassem os abrigos em relação às instalações físicas, à higiene, à ventilação, à iluminação e à segurança. As opiniões emitidas estão organizadas na Tabela 19:

Tabela 19: Opinião dos 67 trabalhadores entrevistados, em relação à situação do abrigo.

\begin{tabular}{lcccccc}
\hline Avaliação do abrigo & \multicolumn{2}{c}{ BOM } & \multicolumn{2}{c}{ REGULAR } & \multicolumn{2}{c}{ INSATISFATÓRIO } \\
\cline { 2 - 7 } & $\mathbf{N}$ & $\%$ & $\mathbf{N}$ & $\%$ & $\mathbf{N}$ & $\%$ \\
\hline instalações fisicas & 40 & 59,7 & 16 & 23,9 & 11 & 16,4 \\
higiene & 62 & 92,5 & 5 & 7,5 & - & - \\
ventilação & 60 & 89,5 & 5 & 7,5 & 2 & 3,0 \\
iluminação & 52 & 77,6 & 12 & 17,9 & 3 & 4,5 \\
segurança & 30 & 44,8 & 21 & 31,3 & 16 & 23,9 \\
\hline
\end{tabular}

Os trabalhadores apresentaram maior consenso ao avaliarem como bom os itens higiene, ventilação e iluminação. Quanto às instalações físicas, embora a maioria $(59,7 \%)$ as considerasse boas, $40,3 \%(23,9 \%+16,4 \%)$ as consideravam regular ou insatisfatória. As opiniões dividiram-se, pois alguns abrigos funcionavam em estrutura ampla e bem distribuída, enquanto outros apresentavam necessidade visível de reforma ou até de 
mudança de espaço físico. No item segurança, as opiniões foram mais variadas, sendo que $44,8 \%$ a consideravam boa; $31,3 \%$, regular; e $23,9 \%$, insatisfatória. Vale ressaltar que somente um abrigo contava com trabalhadores que exerciam a função de segurança (Tabela 19).

Figura 12: Grau de satisfação dos entrevistados com o trabalho que desenvolviam no abrigo $(\mathrm{N}=67)$.

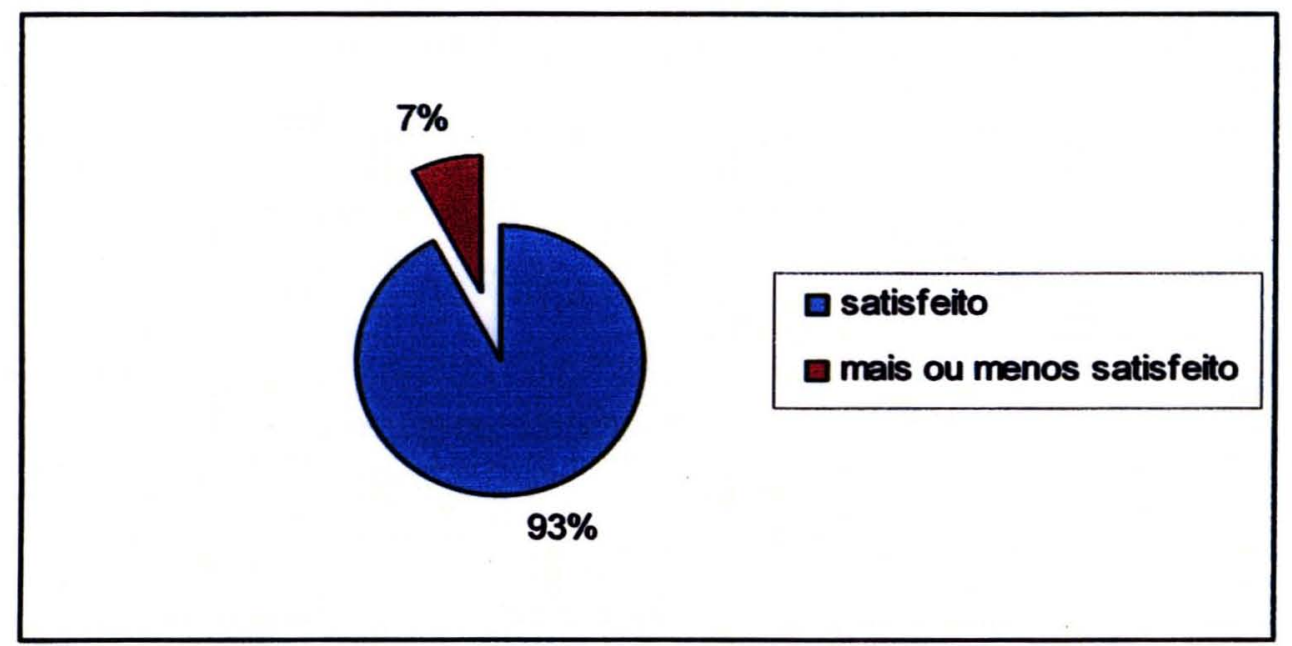

Quanto ao grau de satisfação em relação ao trabalho desenvolvido no abrigo, a grande maioria (93\%) dos trabalhadores manifestou estar satisfeita (Figura 12), principalmente, pelo relacionamento com as crianças e adolescentes, pela possibilidade de ajudar pessoas, pelo aprendizado e "crescimento" e, ainda, por considerar o trabalho gratificante.

Os trabalhadores (7\%) que disseram estar relativamente satisfeitos justificaram a resposta da seguinte forma: um considerava que os trabalhadores deveriam ter mais preparo; outro percebia que poderia fazer mais do que fazia; um relatou que estava com problema pessoal de saúde; outro disse que sentia a saída de algumas crianças; e um não especificou o motivo. Nenhum trabalhador declarou-se insatisfeito com o trabalho.

MARTINEZ e col. (2004), MARTINEZ e PARAGUAY (2001), LENZI e CORREAA (2000) e TAMOYO (1998) definem satisfação no trabalho como um estado subjetivo, que está sujeito a influências de forças internas e externas ao ambiente de 
trabalho imediato, baseado, em parte, pelo que o indivíduo pensa e em parte pelo que sente. O grau de satisfação pode interferir na saúde física e mental do trabalhador, influenciando o seu comportamento profissional e/ou social. Por ser um estado subjetivo, é possível compreender a variação do grau de satisfação em um mesmo ambiente de trabalho.

Para MARTINEZ e col. (2004), TAMOYO (1998) e FERNANDES e GUTIERREZ (1988), os elementos causais de satisfação no trabalho estão relacionados ao próprio trabalho e ao seu conteúdo, ao reconhecimento, ao sistema de promoções, às condições e ao ambiente de trabalho, às relações com os colegas, à liberação do potencial criativo, à retroinformação (feedback) sobre o desempenho, às características de supervisão e ao gerenciamento, entre outros

O fato de a grande maioria estar satisfeita com o trabalho nos abrigos demonstra que eles atribuem maior valor aos aspectos positivos, principalmente, pela contribuição social que ele representa.

Tabela 20: Dificuldades encontradas no exercício da função, segundo relato dos entrevistados.

\begin{tabular}{lcc}
\hline Dificuldades encontradas & $\mathbf{N}^{\circ}$ & $\%$ \\
\hline comportamento das crianças/adolescentes & 10 & 20,0 \\
falta de conhecimentos & 6 & 12,0 \\
número insuficiente de funcionários & 6 & 12,0 \\
ausência de apoio do governo & 6 & 12,0 \\
dificuldades no relacionamento com os colegas de trabalho & 5 & 10,0 \\
instalações fisicas precárias & 4 & $\mathbf{8 , 0}$ \\
falta de materiais de consumo & 2 & 4,0 \\
falta de reconhecimento da sociedade & 2 & 4,0 \\
outros & $\mathbf{9}$ & $\mathbf{1 8 , 0}$ \\
\hline Total & $\mathbf{5 0}$ & $\mathbf{1 0 0 , 0}$ \\
\hline & & (múltipla escolha)
\end{tabular}

Apesar do elevado grau de satisfação com o trabalho realizado, quarenta trabalhadores relataram encontrar dificuldades no exercício da função e vinte e sete trabalhadores disseram que não tinham qualquer dificuldade. 
Dos que relataram dificuldades, dez $(20 \%)$ consideraram que o problema estava relacionado, principalmente, ao comportamento das crianças e adolescentes (Tabela 20), sobretudo quando chegava uma nova criança ou adolescente, interferindo na dinâmica existente e no equilíbrio já alcançado, pois, segundo os funcionários, "os novos chegavam com vícios que os demais queriam adotar". Outras causas referidas foram: a baixa autoestima das crianças e adolescentes; a falta de respeito com o colega; as "barreiras" quando chegavam ao abrigo, criando obstáculos no relacionamento; o fato de alguns acharem que não precisavam estudar; a evasão (fuga) dos adolescentes; e a dificuldade de orientá-los.

Segundo SILVA (1997), as lembranças da vida sócio-afetiva anterior, a dependência materna, as preferências pessoais, o apego a coisas e objetos são fatores que dificultam o processo de institucionalização, e, quanto maior a idade, mais difícil é a substituição do referencial sócio-familiar pelo institucional.

O autor explica que a fuga do espaço institucional significa a busca de liberdade para o corpo, e o desenvolvimento do mecanismo de resistência representa o esforço para a preservação da subjetividade do indivíduo. A intensidade dessa resistência será determinada pelo quanto de auto-estima o indivíduo consegue reunir para motivar suas atitudes.

Seis (12\%) entrevistados reconheciam que a dificuldade estava na falta de capacitação (Tabela 20), conseqüência da insuficiência de cursos específicos para o exercício da função, além da falta de informações sobre as crianças e adolescentes, sobre o motivo da institucionalização e o desconhecimento sobre as doenças que eles apresentavam.

Outros seis (12\%) consideravam insuficiente o número de funcionários (Tabela 20), gerando uma sobrecarga para o pouco tempo de trabalho, e sentiam a falta de um número maior de educadores e de profissionais técnicos especializados, entre eles, psicólogos e médicos. 
Alguns (6 - 12\%) atribuíram as dificuldades à ausência de apoio do governo, sobretudo relativo ao repasse de verbas. Cinco (10\%) trabalhadores relataram dificuldades no relacionamento com os colegas de trabalho, quatro $(8 \%)$ queixaram-se da precariedade das instalações físicas, dois (4\%) falaram da falta de materiais de consumo, principalmente, devido ao alto custo de medicamentos, e dois (4\%) reclamaram da falta de reconhecimento e solidariedade, por parte da sociedade, que ainda discriminava as crianças e adolescentes (Tabela 20).

Outras dificuldades citadas foram: os entraves legais e a lentidão da justiça; as regras rígidas dos abrigos e a falta de autonomia; a dependência de doações; o fato de não haver intercâmbio entre as entidades; a dificuldade de diagnosticar algumas doenças; o pouco tempo para desenvolver o trabalho; e a falta de experiência em trabalhar com crianças.

Em pesquisa realizada por SIQUEIRA e COLETA (1989), com profissionais de empresas comerciais e industriais em Uberlândia - MG, as maiores freqüências sobre ocorrências desagradáveis no trabalho foram: interações pessoais; condições de trabalho e política de recursos humanos. Os resultados revelam que essas dificuldades não ocorrem somente em organizações da área social.

De acordo com MORIN (2001), para que o trabalho estimule o comprometimento daquele que o realiza, ele deve apresentar seis propriedades: variedade e desafio; aprendizagem contínua; margem de manobra e autonomia; reconhecimento e apoio; contribuição social que faça sentido; futuro desejável. Percebe-se, no relato dos entrevistados, que alguns desses fatores estimulantes não eram encontrados nas entidades de abrigo e por isso foram citados como dificuldades no exercício das funções. 
Tabela 21: Causas das dificuldades encontradas no exercício da função, de acordo com os entrevistados.

\begin{tabular}{lcc}
\hline Causas das dificuldades & $\mathbf{N}^{\mathbf{0}}$ & $\%$ \\
\hline poucas verbas & 9 & 19,6 \\
características pessoais dos funcionários / crianças & 8 & 17,4 \\
falta de formação específica dos funcionários & 6 & 13,1 \\
instalações físicas precárias & 3 & 6,5 \\
motivos familiares e comportamentais & 3 & 6,5 \\
tempo escasso & 2 & 4,3 \\
número insuficiente de funcionários / voluntários & 2 & 4,3 \\
dinâmica de funcionamento do abrigo & 1 & 2,2 \\
outros & 12 & 26,1 \\
\hline Total & $\mathbf{4 6}$ & $\mathbf{1 0 0 , 0}$ \\
\hline & \multicolumn{2}{c}{ (múltipla escolha) }
\end{tabular}

Quanto às causas das dificuldades encontradas no exercício da função, nove $(19,6 \%)$ trabalhadores atribuíram às poucas verbas e oito $(17,4 \%)$, às características pessoais dos funcionários e das crianças e adolescentes (Tabela 21). Entre as características indesejáveis dos funcionários, foram citadas: autoritarismo; egoísmo; individualidade; falta de interesse e de dedicação; diversidade de conduta e dificuldade em lidar com os voluntários. Em relação às características das crianças, eles salientaram a agressividade e os "vícios"; termo utilizado, tanto para se referir aos hábitos inadequados, quanto ao consumo de drogas.

Seis $(13,1 \%)$ funcionários consideravam que o motivo das dificuldades era a falta de formação específica para o exercício das suas funções (Tabela 21), sendo difícil encontrar pessoas qualificadas. Entre os que já estavam trabalhando, havia alguns que não sabiam como suprir as necessidades afetivas das crianças; havia, também, dúvidas sobre os medicamentos prescritos para as crianças e adolescentes; faltava, ainda, orientação sobre as atividades a serem desenvolvidas; bem como, condições financeiras para que muitos deles pudessem freqüentar um curso superior.

Três $(6,5 \%)$ trabalhadores atribuíram as dificuldades à precariedade das instalações físicas, três $(6,5 \%)$, aos motivos familiares e comportamentais, oriundos do risco social que 
as crianças e adolescentes haviam vivenciado e, também, dos abusos e maus tratos sofridos (Tabela 21).

Dois $(4,3 \%)$ consideravam que as dificuldades eram motivadas pelo pouco tempo para desenvolver o trabalho e, para dois entrevistados $(4,3 \%)$, havia número insuficiente de funcionários e voluntários. Um $(2,2 \%)$ atribuiu a dificuldade à dinâmica de funcionamento do abrigo, isto é, à inflexibilidade das regras (Tabela 21).

Vinte e três trabalhadores, dos vinte e sete que disseram não ter dificuldades, confirmaram a opinião.

Observou-se que os trabalhadores não citaram a alta rotatividade dos funcionários como um problema na dinâmica de trabalho, o que sugere que, talvez, ainda não tenham refletido sobre as conseqüências dessa rotatividade, tanto para as crianças e adolescentes, como para a equipe em si.

Tabela 22: Sugestões dos entrevistados para melhorar as condições de trabalho.

\begin{tabular}{lcc}
\hline Sugestões & $\mathbf{N}^{\circ}$ & $\%$ \\
\hline promover a integração da equipe & 10 & 17,2 \\
realizar cursos de formação & 9 & 15,5 \\
admitir um número maior de trabalhadores/ voluntários & $\mathbf{8}$ & 13,8 \\
melhorar as instalações físicas & 8 & 13,8 \\
regularizar a situação trabalhista & 5 & $\mathbf{8 , 6}$ \\
estimular maior participação da comunidade & 4 & 6,9 \\
aumentar verbas & 3 & 5,2 \\
adquirir novos equipamentos & 2 & 3,5 \\
outros & 9 & 15,5 \\
\hline Total & $\mathbf{7 4}$ & $\mathbf{1 0 0 , 0 0}$ \\
\hline & & (múltipla escolha)
\end{tabular}

Para melhorar as condições de trabalho, dez (17,2\%) trabalhadores sugeriram promover a integração da equipe (Tabela 24), visando maior união, mais diálogo e bom humor no trabalho, o que evidenciou a existência de problemas de relacionamento interpessoal nas equipes. 
Nove $(15,5 \%)$ sugeriram a realização de cursos de formação, de capacitação e de conscientização, oito $(13,8 \%)$ propuseram a admissão de mais trabalhadores e elevação do número de voluntários e oito $(13,8 \%)$ citaram a necessidade de melhorar as instalações fisicas e investir em segurança (Tabela 22).

Cinco $(8,6 \%)$ trabalhadores sugeriram a regularização da situação trabalhista (Tabela 22), pela assinatura da carteira de trabalho, melhoria salarial, remuneração mínima no valor de um salário mínimo, vale-transporte, exames pré-admissionais e pósdemissionais e pagamento em dia. Estas sugestões reforçaram a observação de que alguns trabalhadores não tinham seus direitos trabalhistas respeitados.

Para FARIA e STANISCI (1990), a ausência de planos de carreira, a falta de perspectiva de melhoria de posição e a baixa remuneração profissional na área social são fatores de desestímulo aos trabalhadores.

Quatro (6,9\%) trabalhadores sugeriram maior participação da comunidade e mais doações. Três $(5,2 \%)$ funcionários disseram que era preciso aumentar as verbas destinadas aos abrigos e dois $(3,5 \%)$ consideravam necessário adquirir novos equipamentos, entre eles, eletrodomésticos, materiais esportivos, arquivo e móvel com gavetas (Tabela 22).

Outras sugestões apresentadas foram: aceitação da opinião das crianças, adolescentes e funcionários; reforço escolar; busca de parceiros que ajudassem a concretizar o plano de atendimento; complementação do histórico e da documentação das crianças e adolescentes; incentivo à elevação da auto-estima das crianças e adolescentes; imposição de limites às crianças e adolescentes, em relação ao trato com os educadores; divisão das crianças por faixa etária; aumento do número de entidades de abrigo e local para encaminhar as crianças que estavam crescendo.

Percebeu-se que alguns trabalhadores reconheciam a necessidade de promoção de cursos de formação e elevação do número de trabalhadores para melhoria da qualidade do 
atendimento prestado, ao mesmo tempo em que observavam a necessidade de maior participação e colaboração da comunidade. Observou-se, ainda, a deficiência em relação ao histórico de vida e documentação das crianças e adolescentes, além de dificuldades no processo educacional.

Torna-se importante evidenciar que um trabalhador sugeriu aumentar o número de abrigos, o que leva a crer que não houve reflexão sobre a necessidade de se trabalhar a origem dos problemas que ainda levam à institucionalização de crianças. Certamente, não será o aumento do número de abrigos que contribuirá para a resolução de problemas sociais como violência, maus tratos, miséria, entre outros.

Dezesseis trabalhadores não apresentaram sugestões, alguns porque estavam satisfeitos, outros porque acreditavam que não havia como melhorar e outros, ainda, por não saber o que sugerir ou por não desejar fazê-lo. A opção por não sugerir demonstrou a situação cômoda, sem reflexão e pessimista em que esses trabalhadores se encontravam.

No trabalho realizado por SIQUEIRA e COLETA (1989), as sugestões dos profissionais das empresas de Uberlândia - MG para melhoria da vida no trabalho em muito coincidem com as sugestões dos profissionais das entidades de abrigo: alterações na política de recursos humanos, incluindo contratação de outros servidores e implantação de cursos e treinamentos; melhoria das condições de trabalho, com adequação do espaço físico e equipamentos de trabalho; oportunidade de colocação de idéias, maior valorização, mais autonomia e reconhecimento; melhoria nas relações com os colegas, maior colaboração, confiança e amizade.

O fato de duas pesquisas sobre dificuldades encontradas no processo trabalho, em distintos ramos de atividades, terem obtido respostas semelhantes sugere que as insatisfações parecem não depender da área de atuação. 
Segundo LENZI e CORREAA (2000) e VIEIRA (1997), muitas frustrações no trabalho estão relacionadas à falta de uma política direcionada à satisfação profissional nas organizações, com o objetivo de se atingir melhor qualidade na prestação de serviços.

Figura 13: Percep̧̧̃̃o dos trabalhadores, em relação ao seu desenvolvimento profissional dentro do abrigo.

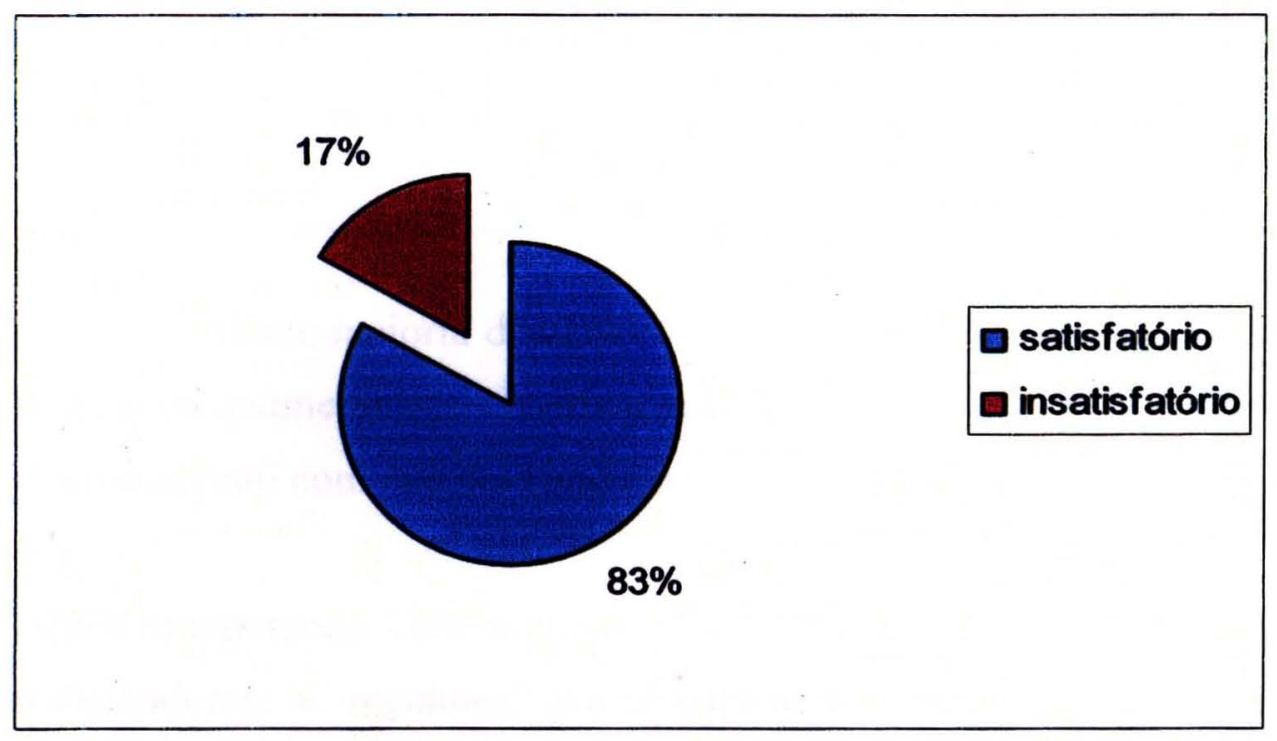

(Múltipla escolha)

Em relação ao desenvolvimento profissional nos abrigos, alguns trabalhadores manifestaram-se satisfeitos, pois afirmaram que estavam aprendendo muito e crescendo profissionalmente, além de gostarem do trabalho que faziam. Outros se disseram satisfeitos, porém com falas do tipo "não tenho reclamação" ou "faço o possível", o que mais uma vez evidencia o comodismo no trabalho realizado. Cinco entrevistados mostraram-se satisfeitos com o trabalho, mas manifestaram algumas preocupações em relação ao que acontecia com as crianças quando saiam do abrigo e com as falhas no atendimento, devido à alta demanda.

Quanto aos aspectos de insatisfação foram citados: a falta de conhecimento específico e a necessidade de cursos da capacitação; a falta de reconhecimento do trabalho realizado; a percepção de que o trabalho poderia ser melhor desenvolvido; e a sensação de estagnação profissional. 
Tabela 23: Opinião dos entrevistados sobre o seu relacionamento interpessoal no ambiente de trabalho.

\begin{tabular}{|c|c|c|c|c|c|c|c|c|}
\hline \multirow{2}{*}{$\begin{array}{l}\text { Avaliação do seu } \\
\text { relacionamento com }\end{array}$} & \multicolumn{2}{|c|}{ Bom } & \multicolumn{2}{|c|}{ Regular } & \multicolumn{2}{|c|}{ Não se aplicava } & \multicolumn{2}{|c|}{ Total } \\
\hline & $\mathbf{N}$ & $\%$ & $\mathbf{N}$ & $\%$ & $\mathbf{N}$ & $\%$ & $\mathbf{N}$ & $\%$ \\
\hline a direção & 51 & 76,1 & 5 & 7,5 & 11 & 16,4 & 67 & 100,0 \\
\hline a coordenação & 56 & 83,6 & 5 & 7,5 & 6 & 8,9 & 67 & 100,0 \\
\hline os outros funcionários & 59 & 88,1 & 7 & 10,4 & 1 & 1,5 & 67 & 100,0 \\
\hline as crianças e adolescentes & 64 & 95,5 & 3 & 4,5 & - & - & 67 & 100,0 \\
\hline
\end{tabular}

$\mathrm{Na}$ opinião da grande maioria dos entrevistados as relações interpessoais dentro do abrigo eram boas, principalmente com as crianças e adolescentes (95,5\%). Apenas em 4,5\% dos casos o relacionamento com eles foi considerado regular (Tabela 23).

As relações interpessoais com os demais trabalhadores eram consideradas boas, por $88,1 \%$ dos trabalhadores, e regulares, por 10,4\% deles; situação já manifestada em questionamentos anteriores. Quanto ao relacionamento com a coordenação do abrigo, $83,6 \%$ dos funcionários entendiam como bom e 7,5\% deles o consideravam regular. Também foi avaliado como bom o relacionamento com a direção, por $76,1 \%$ dos trabalhadores, e como regular, por 7,5\% deles (Tabela 23).

Em alguns casos considerou-se que a avaliação não se aplicava pelo fato do profissional ocupar a função de coordenação ou de direção. Em outras situações não houve avaliação porque o funcionário não tinha contato com a direção ou com os outros trabalhadores, o que ressaltou que pessoas que trabalhavam por objetivos comuns não tinham a oportunidade de se relacionar e trocar informações e experiências.

Nenhum trabalhador considerou o seu relacionamento interpessoal ruim.

As relações interpessoais, a valorização e o investimento no potencial humano, o estabelecimento de parcerias, o trabalho em equipe e o compartilhamento de metas e valores, cada vez mais devem ser cuidadosamente avaliados para que se alcance sucesso nas organizações. 
Segundo FATHEAZAM (2000), LENZI e CORREAA (2000), TAMOYO (2000) e MORIN (2001), é necessária uma liderança forte, que transmita energia, entusiasmo e paixão. Deve-se criar um ambiente de aprendizagem contínua, de treinamento e educação, de maior engajamento e lealdade por parte dos trabalhadores, além de se buscar aproximar os valores pessoais dos organizacionais, pois a correspondência entre as exigências do trabalho e os valores, interesses e competências do indivíduo, gera maior interesse pelo trabalho. Atualmente, há a necessidade de se administrar com as pessoas e não as pessoas, de modo que o profissional aja como um colaborador e parceiro e não como um empregado.

Tabela 24: Opinião dos trabalhadores sobre as relações interpessoais com as crianças e adolescentes.

\begin{tabular}{|c|c|c|c|c|c|c|c|c|c|c|}
\hline \multirow[t]{2}{*}{$\begin{array}{l}\text { Relacionamento com as } \\
\text { crianças e adolescentes }\end{array}$} & \multicolumn{2}{|c|}{ Bom } & \multicolumn{2}{|c|}{ Regular } & \multicolumn{2}{|c|}{ Ruim } & \multicolumn{2}{|c|}{$\begin{array}{c}\text { Não se } \\
\text { aplicava ou } \\
\text { não sabia }\end{array}$} & \multicolumn{2}{|c|}{ Total } \\
\hline & $\mathbf{N}$ & $\%$ & $\overline{\mathbf{N}}$ & $\%$ & $\mathbf{N}$ & $\%$ & $\mathbf{N}$ & $\%$ & $\mathbf{N}$ & $\%$ \\
\hline da direção & 50 & 74,6 & 7 & 10,4 & 1 & 1,5 & 9 & 13,5 & 67 & 100,0 \\
\hline da coordenação & 59 & 88,0 & 2 & 3,0 & 2 & 3,0 & 4 & 6,0 & 67 & 100,0 \\
\hline dos outros funcionários & 54 & 80,6 & 11 & 16,4 & - & - & 2 & 3,0 & 67 & 100,0 \\
\hline
\end{tabular}

Foi solicitada a opinião dos trabalhadores sobre o relacionamento da direção, da coordenação e dos demais funcionários com as crianças e adolescentes. A grande maioria relatou que o relacionamento interpessoal com os institucionalizados era bom, embora alguns considerassem que o relacionamento era regular (Tabela 24).

Um trabalhador disse que o relacionamento da direção com as crianças e adolescentes era ruim e dois disseram que a relação interpessoal da coordenação com eles, também, era ruim, embora, talvez por receio, não tenham explicado o por quê. De todo modo, o relato torna-se extremamente preocupante, em função do papel que esses trabalhadores exercem na vida dessas crianças e adolescentes e do reflexo que tal conduta poderá ter no desenvolvimento desses indivíduos (Tabela 24). 
Oito entrevistados relataram que a direção não tinha contato com as crianças e adolescentes. Alguns trabalhadores não souberam responder, por não presenciarem a forma de relacionamento dentro do abrigo ou por estarem a pouco tempo no trabalho.

Mais uma vez evidencia-se que alguns "gestores de vidas" nem sequer tinham contato com as crianças e adolescentes pelos quais tomavam decisões e que nem todos os trabalhadores exerciam suas funções de forma integrada com os demais colegas e, também, com os institucionalizados, uma vez que não presenciavam como se davam as relações interpessoais.

\section{Tabela 25: Motivos que levaram os entrevistados a trabalharem em um abrigo.}

\begin{tabular}{lcc}
\hline Motivos que o levaram a trabalhar em abrigo & $\mathbf{N}^{\circ}$ & $\%$ \\
\hline necessidade financeira/ oportunidade de trabalho & 30 & 37,4 \\
indicação & 19 & 23,8 \\
interesse pela clientela & 19 & 23,8 \\
motivo religioso & 4 & 5,0 \\
solidariedade & 4 & 5,0 \\
outros & 4 & 5,0 \\
\hline Total & $\mathbf{8 0}$ & $\mathbf{1 0 0 , 0}$ \\
\hline & & (múltipla escolha)
\end{tabular}

Entre os motivos que levaram os entrevistados a trabalharem nos abrigos, a necessidade financeira e a oportunidade de trabalho apresentaram a maior freqüência $(37,4 \%)$, seguidas pela indicação de pessoa conhecida $(23,8 \%)$ e interesse pela clientela das entidades de abrigo (23,8\%). Os motivos religiosos (5\%) e a solidariedade (5\%), também, foram citados como um incentivo do trabalho em abrigo (Tabela 25).

Os outros motivos citados foram: busca de experiência; curiosidade; desejo de sair da rotina; vocação.

Percebeu-se que a razão financeira foi o fator motivador que levou mais de um terço dos profissionais a trabalhar nos abrigos, sobrepondo-se aos motivos de ideal profissional e 
auxílio ao próximo. No entanto, entre os fatores que mantinham os trabalhadores nos abrigos, a necessidade financeira $(18,8 \%)$ foi superada pela satisfação com o trabalho desenvolvido $(33,8 \%)$ e pelo amor pelas crianças $(32,5 \%)$ (Tabela 26$)$.

\section{Tabela 26: Motivos que mantêm os entrevistados trabalhando em um abrigo.}

\begin{tabular}{lcc}
\hline Motivos que os mantêm trabalhando em abrigo & $\mathbf{N}^{\circ}$ & $\%$ \\
\hline satisfação com o trabalho & 27 & 33,8 \\
as crianças & 26 & 32,5 \\
necessidade financeira & 15 & 18,8 \\
desafios/metas & 4 & 5,0 \\
falta de alternativa de emprego & 4 & 5,0 \\
motivo religioso & 3 & 3,7 \\
sair da rotina & 1 & 1,2 \\
\hline Total & $\mathbf{8 0}$ & $\mathbf{1 0 0 , 0 0}$ \\
\hline & \multicolumn{3}{c}{ (múltipla escolha) }
\end{tabular}

Quatro trabalhadores disseram que a razão de permanecerem trabalhando em entidade de abrigo era o desafio da atividade e as metas a cumprir (5\%). Outros quatro relataram a falta de alternativa de emprego (5\%), o que confirma que alguns trabalhadores não exerciam as atividades nos abrigos por desejo próprio. Os motivos religiosos foram mantidos por três trabalhadores $(3,7 \%)$ e o desejo de sair da rotina foi mais uma vez citado por um trabalhador $(1,2 \%)$ (Tabela 26$)$.

Para MORIN (2001), o trabalho é uma necessidade, uma dimensão importante na vida das pessoas. $\mathrm{O}$ trabalho coloca as pessoas em relação com as outras, o que contribui para o desenvolvimento de suas identidades, além de permitir um sentimento de segurança e possibilitar ser autônomo e independente. Ele ocupa o tempo de vida e lhe dá sentido. E é esse sentido que gera a satisfação. Possivelmente, esta seja a explicação da inversão de valores dos trabalhadores com o passar do tempo nas entidades de abrigo e com a relação que estabelecem com as crianças e adolescentes. 


\subsubsection{Programa de educação continuada.}

Procurou-se verificar se os trabalhadores consideravam necessário o desenvolvimento de um programa de educação continuada, para melhor realizarem as atividades nos abrigos $\mathrm{e}$ melhor contribuírem com as crianças $\mathrm{e}$ adolescentes institucionalizados.

Figura 14: Percepção da necessidade de desenvolvimento de um programa de educação continuada $(\mathbf{N}=67)$.

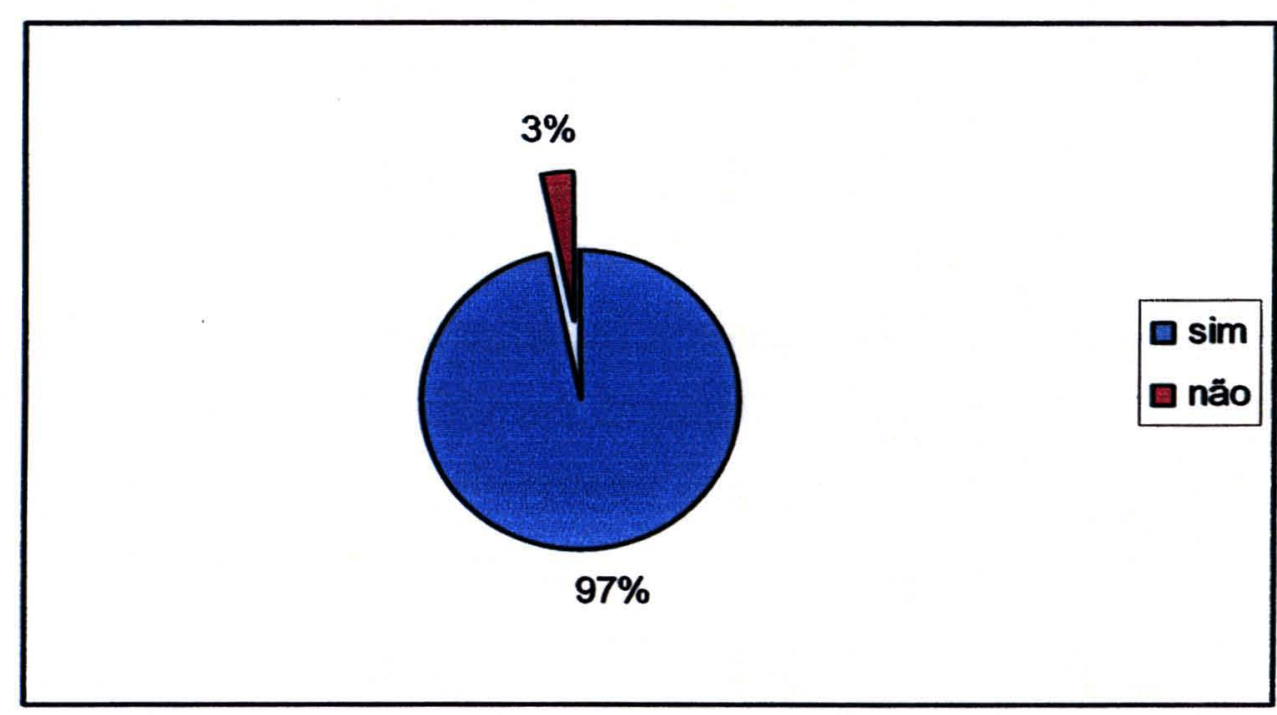

Embora, quando questionados sobre as dificuldades no exercício da função, somente seis trabalhadores tenham atribuído à falta de formação, e para melhorar as condições de trabalho, apenas nove tenham sugerido a realização de cursos, diante do questionamento sobre a necessidade de implantação de um programa de educação continuada, a grande maioria (97\%) respondeu positivamente e apenas $3 \%$ deles consideraram não ser necessário (Figura 14).

O resultado demonstra que a necessidade de formação específica e de realização de cursos era sentida por poucos, mas diante da possibilidade de oferta de qualificação, os trabalhadores mostraram-se receptivos, o que pode facilitar a implantação de um programa educativo. 
Tabela 27: Conhecimentos que gostariam de adquirir para melhorar a execução das suas atividades.

\begin{tabular}{lcc}
\hline Conhecimentos que gostariam de adquirir & $\mathbf{N}^{\circ}$ & $\%$ \\
\hline conhecimentos na área de psicologia & 21 & 28,4 \\
conhecimentos na área de saúde & 12 & 16,2 \\
conhecimentos na área social & 11 & 14,9 \\
conhecimentos na área de educação/cuidados pessoais & 7 & 9,4 \\
informática & 5 & 6,8 \\
culinária & 3 & 4,0 \\
trabalhos manuais/artesanato & 2 & 2,7 \\
serviços gerais & 2 & 2,7 \\
outros & 11 & 14,9 \\
\hline Total & $\mathbf{7 4}$ & $\mathbf{1 0 0 , 0}$ \\
\hline & & (múltipla escolha)
\end{tabular}

Dos trabalhadores que manifestaram a necessidade de um programa de educação continuada, vinte e um $(28,4 \%)$ gostariam de adquirir conhecimentos na área de psicologia e doze $(16,2 \%)$ tinham interesse em receber informações sobre a área de saúde. Onze $(14,9 \%)$ trabalhadores relataram interesse por temas na área social e sete $(9,4 \%)$, por temas relacionados à educação e cuidados pessoais (Tabela 27). Informações nessas quatro grandes áreas, certamente, são essenciais para trabalhadores que se dedicam ao atendimento de crianças e adolescentes institucionalizados, pois estão diretamente relacionados à história de vida, saúde, educação e desenvolvimento dos mesmos.

Outras áreas de interesse citadas foram: informática (6,8\%); culinária (4\%); trabalhos manuais/artesanato $(2,7 \%)$; serviços gerais $(2,7 \%)$. As onze demais sugestões estavam relacionadas à prática diária nos abrigos. Quatro trabalhadores optaram por não sugerir (Tabela 27).

Os temas sugeridos para um curso de educação continuada estão organizados no Quadro 8: 


\section{Quadro 8: Temas sugeridos para um curso de educação continuada.}

\begin{tabular}{ll}
\hline Área & Temas sugeridos \\
\hline saúde & $\begin{array}{l}\text { AIDS } \\
\text { desenvolvimento infantil } \\
\text { drogas e dependência química } \\
\text { enfermagem } \\
\text { higiene } \\
\text { portadores de necessidades especiais } \\
\text { primeiros socorros } \\
\text { sexualidade }\end{array}$ \\
psicologia & $\begin{array}{l}\text { aspectos emocionais } \\
\text { família } \\
\text { relações interpessoais } \\
\text { rejeição } \\
\text { violência }\end{array}$ \\
& alfabetização especial \\
papel do educador & cidadania \\
educação & recepção/atendimento \\
social & culinária \\
administrativa & \\
culinária & \\
\hline
\end{tabular}

Os temas foram organizados com o objetivo didático, porém compreende-se que ao se considerar o ser humano como ser integral e inserido em um meio social, os temas devem ser tratados de forma integrada, com uma abordagem interdisciplinar.

FARIA e STANISCI (1990) sugeriram os seguintes temas para um curso de formação de educadores: contexto socioeconômico, político e cultural em que se insere a questão da criança e do adolescente; políticas públicas de atendimento às crianças e adolescentes; pedagogia de intervenção; conceitos de infância e adolescência; modelos significativos na formação de identidade; análise da história de vida de crianças e adolescentes marginalizados, incluindo família, escola, trabalho, saúde, sexualidade, drogas, violência, questão racial. 
Os temas citados pelos autores são muito pertinentes, mas é necessário ressaltar que não basta reproduzir a experiência de um curso, embora as idéias possam, em muito, colaborar. No processo educativo com trabalhadores, é muito importante a participação deles na construção da proposta, uma vez que esta deve ser baseada nos conhecimentos prévios e na experiência do grupo em foco, para que se possa, de fato, corresponder às expectativas e alcançar os objetivos. 


\section{CONCLUSÕES}




\section{CONCLUSÕES}

A presente investigação, sobre a dinâmica realidade das sete entidades de abrigo de crianças e adolescentes existentes município de Vitória-ES, incluiu as formas de organização administrativa, o perfil dos institucionalizados $e$ as características e opiniões dos trabalhadores em exercício, tendo se chegado às seguintes conclusões:

Quanto às características das entidades de abrigo:

Todos os abrigos eram Organizações Não Governamentais (ONGs), regularmente constituídas, e arrecadavam recursos por meio de contribuições de associados, contribuições de doadores espontâneos, auxílio de outras ONGs ou eram subvencionados por alguma Secretaria Municipal.

Possuiam capacidade total instalada para atender 109 crianças e adolescentes e recebiam crianças abandonadas, vítimas de maus tratos, negligência e violência sexual, portadores de excepcionalidade mental, portadores de necessidades físicas especiais e portadores do vírus HIV, de acordo com o público a que cada uma se destinava. Para atender a essa demanda, contavam com um total de 73 trabalhadores.

Três entidades atendiam exclusivamente crianças e adolescentes do sexo masculino, duas exclusivamente do sexo feminino e outras duas de ambos os sexos.

A faixa etária do público atendido era estabelecida em cada abrigo, variando entre 0 e 18 anos incompletos.

\section{Em relação às crianças e adolescentes:}

No levantamento realizado em 2002, havia 91 crianças e adolescentes institucionalizados no município de Vitória - ES, dos quais $58 \%$ pertenciam ao sexo feminino. 
Com referência à idade das crianças $e$ adolescentes no ato da institucionalização, ocorreu maior freqüência durante a primeira infância ( 1 mês $\vdash 4$ anos), 39,5\%, seguida da adolescência (13 anos $\vdash 17$ anos), $26,4 \%$, sendo que $16,5 \%$ das crianças foram institucionalizadas antes de completar um ano de vida

Quanto ao tempo de institucionalização, 61,5\% das crianças e adolescentes estavam institucionalizados há menos de um ano e somente $3,3 \%$ estavam institucionalizados há mais de seis anos.

\section{Com referência à organização administrativa:}

Os responsáveis de cinco abrigos atuavam nas próprias entidades e dois, trabalhavam nas instituições mantenedoras, participando pouco dos acontecimentos diários.

Em $68,8 \%$ dos casos, os responsáveis pelo encaminhamento das crianças e adolescentes para os abrigos eram as autoridades judiciárias e os conselhos tutelares.

A rotina apresentou-se semelhante entre os abrigos, com definição de horários e baseada em regras estabelecidas.

Somente três entidades possuíam um Plano de Trabalho compatível com os princípios do Estatuto da Criança e do Adolescente (ECA) e nem todos os trabalhadores tinham ciência do que era o referido documento.

Nos sete abrigos existiam prontuários individualizados das crianças e adolescentes e, em somente dois, existia o plano individual de atendimento previsto no ECA.

Em todas as entidades havia um processo de recepção e acolhimento na chegada das crianças e adolescentes, com participação de $70,8 \%$ dos trabalhadores. 
Em somente três a quatro das entidades de abrigo havia um programa de incentivo à preservação dos vínculos familiares, estímulo à adoção e à inserção em familia substituta, nos casos de impossibilidade de reaproximação com a família, e não desmembramento de grupos de irmãos.

Em cinco entidades havia transferências de crianças e adolescentes para outros abrigos e também recebimento.

Segundo as responsáveis, todas as entidades realizavam atividades para envolver a comunidade, com participação de $59,3 \%$ dos trabalhadores, embora oito trabalhadores tenham informado o inverso.

As sete entidades incentivavam as crianças e adolescentes à prática religiosa e realizavam atividades de cultura e lazer. Crianças e adolescentes, de quatro das entidades, praticavam atividades esportivas, fora da entidade.

Somente quatro abrigos tinham a totalidade das crianças e adolescentes freqüentando a escola.

A preparação para o dia do desligamento das crianças e adolescentes era realizada por cinco entidades, com a participação de $34 \%$ dos trabalhadores e ênfase para o papel das assistentes sociais e psicólogas.

O acompanhamento dos egressos era realizado por cinco entidades, embora parecesse insuficiente.

Houve incoerência quanto à participação das crianças e adolescentes na execução das tarefas diárias dos abrigos, sendo que $69 \%$ dos entrevistados afirmaram que eles auxiliavam e $31 \%$ disseram o contrário. 


\section{Quanto ao perfil e qualificação dos trabalhadores:}

Dos 67 trabalhadores entrevistados, $87 \%$ pertenciam ao sexo feminino, incluindo todas as responsáveis pelos abrigos, e mais da metade $(57,1 \%)$ exercia a função de educador, embora tenham utilizado diferentes nomenclaturas para a mesma função (educador, monitor, auxiliar de educação e babá), realizando atividades de atenção direta às crianças e adolescentes.

Havia trabalhadores com idade de 18 a 57 anos, sendo a maior freqüência observada na faixa etária de 21 a 30 anos (35,8\%), seguida pela faixa etária de 41 a 50 anos $(29,9 \%)$.

Aproximadamente, metade $(49,2 \%)$ dos funcionários havia freqüentado o ensino médio, $6 \%$ possuiam curso superior incompleto e somente $9 \%$ eram graduados. Os demais haviam freqüentado o ensino fundamental, sendo que um trabalhador era só alfabetizado e outro sabia apenas assinar o nome.

Nenhum trabalhador teve a oportunidade de participar de curso de formação específica para o trabalho em entidade de abrigo, mas ao serem questionados sobre a necessidade de um programa de educação continuada, a grande maioria (97\%) dos trabalhadores manifestou-se positivamente, sugerindo temas nas áreas de psicologia, de saúde, de assistência social e de educação, prioritariamente.

Aproximadamente $75 \%$ dos trabalhadores estavam no exercício de suas funções há, no máximo, dois anos e dois terços $(66,7 \%)$ deles não tinham contato diário com as crianças e adolescentes.

Com referência à situação trabalhista, $25 \%$ atuavam como voluntários. No entanto, alguns informaram receber ajuda de custo. 


\section{Em relação à dinâmica de trabalho:}

A grande maioria (93\%) dos trabalhadores manifestou estar satisfeita em relação ao trabalho desenvolvido no abrigo, embora $59,7 \%$ tenham relatado encontrar dificuldades no exercício da função. Nenhum trabalhador declarou-se insatisfeito com o trabalho.

$\mathrm{Na}$ opinião da grande maioria dos entrevistados, as suas relações interpessoais dentro do abrigo eram boas, principalmente com as crianças e adolescentes $(95,5 \%)$, tendo sido consideradas regulares em $4,5 \%$ dos casos.

A grande maioria dos trabalhadores relatou que o relacionamento interpessoal da direção, da coordenação e dos demais funcionários com os institucionalizados era bom, embora tenha havido relato contrário.

Entre os motivos que levaram os trabalhadores a atuarem nos abrigos, a necessidade financeira e a oportunidade de trabalho representaram a maior frequiência $(37,4)$. No entanto, entre os fatores que mantinham os trabalhadores nas entidades, a necessidade financeira $(\mathbf{1 8 , 8 \%})$ foi superada pela satisfação com o trabalho desenvolvido $(33,8 \%)$ e pelo amor em relação às crianças $(32,5 \%)$.

\section{Com referência ao conceito de saúde e à saúde dos institucionalizados:}

O conceito de saúde dos trabalhadores das entidades ainda apresentava-se restrito, tendo sido ressaltado o bem-estar físico, o bem-estar emocional e a importância da saúde para a vida.

Os abrigos não possuíam profissionais da área de psicologia e de pedagogia contratados; dependiam de voluntários. Os atendimentos de saúde eram realizados fora das instalações das entidades. 
As queixas mais freqüentes apresentadas pelas crianças e adolescentes em relação à saúde física eram: cefaléia, problemas do aparelho gastrintestinal e problemas do aparelho respiratório/otorrinolaringológicos.

Em relação às questões afetivas, a principal queixa relatada era a falta do lar e/ou da família (60\%), sobretudo da mãe ou do pai, ocorrendo, também, a solicitação de atenção e carinho (15\%).

A conduta mais utilizada pelos trabalhadores, frente às queixas das queixas das crianças e adolescentes, era escutar o problema, conversar e orientar $(44,6 \%)$.

Os trabalhadores consideravam que a maior contribuição deles para a saúde das crianças e adolescentes se dava por meio da orientação, da educação e dos cuidados $(65,1 \%)$.

Por fim, entende-se que os objetivos da pesquisa foram alcançados, principalmente, devido às características peculiares das entidades de abrigo de crianças e adolescentes, tendo-se conseguido informações para subsidiar futuros estudos e ações, na área da infância e da juventude. 


\section{CONSIDERAÇÕES FINAIS}




\section{CONSIDERAÇŌES FINAIS}

Chamou atenção o carinho e o envolvimento expressos pela maioria dos trabalhadores entrevistados, em relação às crianças e adolescentes. Observou-se o desejo de transformar a complexa realidade, de interferir, mas sem se saber como. Alguns trabalhadores demonstravam que a falta de informação sobre o motivo da institucionalização e sobre as causas de algumas doenças, além da ausência de conhecimentos específicos para atuarem com crianças e adolescentes, os deixava sem muitos instrumentos para alterarem o quadro estabelecido.

A insegurança nas condutas e ações, também, parece estar relacionada a dúvidas quanto à legislação. Conforme relatado, não havia momentos de reflexão e de discussão sobre práticas pedagógicas e atenção psicossocial, as reuniões eram, basicamente, para tratar de questões do dia-a-dia.

Porém, as entidades de abrigo têm uma missão que vai além daquela definida em dicionário (abrigo = algo que oferece proteção ou refúgio contra dano físico, ataque, perigo). Elas têm a função de cuidar e proteger, mas, também, possuem outra grande responsabilidade, cumprir seu papel social e educacional.

Certamente, a reversão desses problemas sociais, não pode ser atribuída somente às entidades de abrigo, depende, do mesmo modo, ou até mais, da disposição dos diversos poderes públicos e segmentos da sociedade organizada, que, de forma complementar, podem alcançar resultados mais eficientes. 


\section{SUGESTÕES}




\section{SUGESTÕES}

$\mathrm{Na}$ intenção de colaborar com a melhoria da atenção prestada às crianças e adolescentes e diante do que foi apresentado e discutido neste trabalho, sugere-se:

Às diferentes esferas do governo:

- Criar políticas sociais que garantam as condições mínimas para as famílias manterem, dignamente, os seus filhos junto a si, incluindo educação, oportunidade de trabalho, alimentação, moradia, transporte, vestuário, além de outras condições essenciais à vida.

Ao Poder Jurídico:

- Colaborar no sentido de agilizar os processos das crianças e adolescentes institucionalizados e, com isso, criar novas oportunidades de encaminhamento das questões que envolvem a vida dos mesmos, sobretudo quando da impossibilidade de retorno às suas famílias, viabilizando a inserção em famílias substitutas.

Ao CAIJ/MPES:

- Continuar investindo em pesquisa, a fim de diagnosticar, acompanhar, e avaliar a realidade e a dinâmica de funcionamento das entidades de abrigo, em busca, não somente de fiscalizar, mas, também, de colaborar com a reversão da realidade das crianças e adolescentes institucionalizados, tanto por iniciativas próprias, como por meio do estabelecimento de parcerias.

Aos responsáveis pelas entidades de abrigo:

- Estabelecer um protocolo de seleção para admissão de trabalhadores;

- Oferecer treinamento aos trabalhadores recém-admitidos;

- Garantir, junto às entidades mantenedoras, os direitos trabalhistas dos profissionais;

- Manter-se próximo da realidade do abrigo; 
- Construir instrumentos de acompanhamento e avaliação do desempenho dos trabalhadores;

- Viabilizar estratégias de avaliação institucional periódica, com plena participação dos trabalhadores, crianças e adolescentes, e outros que se fizerem importantes, pois críticas construtivas são úteis para alavancar novas posturas e ações;

- Criar uma forma para que sugestões, críticas e opiniões das pessoas possam ser oferecidas às entidades, resguardando as suas identidades, quando desejarem;

- Oportunizar momentos de discussão e construção em equipe, viabilizando, inclusive, a participação das crianças e adolescentes, de modo que todos tenham igual direito de se fazer ouvir, para, juntos, refletirem sobre a realidade em que estão inseridos e buscarem alternativas que tornem mais amena a realidade institucional e a realidade de suas próprias vidas;

- Promover momentos de leitura sobre a temática;

- Instituir momentos de reflexão sobre o papel de cada um no processo de educação das crianças e adolescentes e de avaliação das implicações da prática diária sobre o desenvolvimento dos mesmos e sobre os encaminhamentos dados à vida de cada um deles;

- Dedicar especial atenção aos educadores, no sentido de criar oportunidades para que recebam boa formação e estejam sempre atualizados, por serem os trabalhadores que têm contato mais próximo com as crianças e adolescentes, e que, possivelmente, estabelecem maiores vínculos com eles, colaborando com o desenvolvimento e a saúde dos mesmos;

- Contratar psicólogos e pedagogos para atuarem, de forma mais próxima e freqüente, junto às crianças e adolescentes;

- Estabelecer convênios e parcerias:

- com instituições de ensino, a fim de iniciar um programa de formação e de educação continuada para os trabalhadores;

- com outras instituições e com a sociedade organizada, de modo a criar oportunidades para as crianças e adolescentes e viabilizar a concretização de ações que possam contribuir com a qualidade da atenção prestada aos mesmos. 
Aos trabalhadores das entidades de abrigo:

- Refletir sobre a sua prática profissional e humana, dentro das entidades de abrigo, e sobre o efeito de suas ações na formação individual e coletiva das crianças e adolescentes institucionalizados;

- Buscar leitura que possa contribuir para a atuação profissional;

- Procurar participar de eventos que possam colaborar direta ou indiretamente com a sua formação;

- Criticar de forma construtiva e sugerir alternativas para a solução dos problemas detectados;

- Ter iniciativa, propor ações e lutar contra o comodismo;

- Procurar apoio para as suas necessidades profissionais e pessoais, sobretudo as emocionais;

- Promover o bom relacionamento interpessoal da equipe de trabalhadores, das crianças e adolescentes entre si e de todo o grupo;

- Buscar a integração da equipe, sobretudo quanto às condutas adotadas frente às crianças e adolescentes;

- Atuar de forma profissional, de modo a contribuir de fato com as crianças e adolescentes, sem se afastar dos princípios éticos, humanos e afetivos, essenciais na formação dos mesmos.

Às instituições de ensino superior:

- Incluir nos currículos dos cursos noções básicas de direitos humanos e responsabilidade social;

- Criar oportunidades de direcionar os "olhares", as reflexões e ações dos docentes e discentes para a realidade social;

- Colaborar com as entidades de abrigo, com as crianças e adolescentes institucionalizados e com os trabalhadores das entidades, construindo projetos, proferindo palestras, ministrando cursos, oferecendo atenção à saúde, apoio educacional, entre outros, permitindo, assim, que os conhecimentos gerados no meio acadêmico revertam-se em benefício para essa parcela da sociedade. 
À sociedade organizada:

- Mobilizar-se para proporcionar a inclusão das crianças e adolescentes institucionalizados em atividades culturais, esportivas e de lazer, assim como para integrá-los à dinâmica da comunidade;

- Colaborar direta $\mathrm{e}$ indiretamente com a atenção prestada às crianças e adolescentes institucionalizados.

Como forma de contribuição e incentivo à implantação do programa de formação e de educação continuada para os trabalhadores das entidades de abrigo do município de Vitória - ES, apresenta-se uma proposta de curso de formação básica, estruturada a partir das sugestões apresentadas pelos entrevistados e dos temas relatados na literatura. Foram incluídos, também, temas complementares considerados importantes, tanto para o embasamento teórico, como para a atividade prática deles junto às crianças e adolescentes institucionalizados (Anexo 4).

Pretende-se desenvolver o curso por meio da parceria firmada entre o Centro de Apoio Operacional da Infância e da Juventude do Ministério Público do Estado do Espírito Santo (CAIJ/MPES) e a Instituição de Ensino Superior que apoiou este trabalho. Antes de sua realização, a proposta será apresentada e debatida junto aos trabalhadores, para que possam avaliar e julgar a pertinência, além de colaborar com novas sugestões. Acredita-se que uma proposta somente faz sentido para o público alvo e se pode obter bons resultados, quando o processo de construção é coletivo.

Espera-se que a iniciativa do estudo e da sugestão de implantação do programa de formação e de educação continuada para os trabalhadores de entidades de abrigo estimule outros municípios a construírem seus próprios projetos, com semelhante finalidade, respeitando as necessidades e as características locais e do grupo de pessoas envolvidas. 
REFERÊNCIAS 


\section{REFERÊNCIAS}

Adorno RCF. Educadores em lugar de carcereiros na FEBEM. Hygeia, São Paulo, 1999 set.; (8): 4-6.

Alvarez MAS, Moraes MCL, Rabinovich EP. Resiliência: um estudo com brasileiros institucionalizados. Rev. Bras. Cresc. Des. Hum. 1998; 8(1/2): 70-5.

Anaf C, Paiva AD. Uma experiência numa instituição de abrigo. Psikhê - Rev. Curso Psicol. Cent. Univ. FMU 2000; 5 (2): 52-7.

Ariès P. História social da criança no Brasil. $2^{a}$ ed. Rio de Janeiro: Guanabara; 1981. Da família medieval à família moderna: p. 225-79.

Arpini DM. Adolescência e violência: reflexões a partir da história. Rev. Psicol. Argumento 1999 abr.; (XXIV): 99-112.

Bazon MR. Investir na formação de educadores: uma forma de qualificar os serviços e programas de atenção direta à infância e adolescência. In: Biasoli-Alves ZMM, Fischmann $\mathrm{R}$ (organizadoras). Crianças e adolescentes construindo uma cultura da tolerância. São Paulo: Edusp; 2001. p. 169-81.

Bazon MZ, Biasoli-Alves ZMM. A transformação de monitores em educadores: uma questão de desenvolvimento. Psicol. Reflex. Crit. 2000a; 13 (1).

Bazon MZ, Biasoli-Alves ZMM. Avaliando a implementação de um modelo de atendimento a crianças e adolescentes em situação de risco social. Rev. Bras. Cresc. Des. Hum. 2000b; 10 (1): 61-73.

Borges MV. Privação de cuidados maternos nos primeiros anos de vida: conceituação e observação em uma situação hospitalar. Rev. FSESP 1981; XXVI(1): 79-91. 
Brasil. Constituição Federal de 1988. Capítulo VII, Art. 226 a 230.

Brasil. Estatuto da Criança e do Adolescente. Lei Federal ${ }^{\circ} 8.069 / 90$.

Brasil. Lei Orgânica da Assistência Social - LOAS. Lei Federal nº 6.742/93.

Cariola T, Jaehn SM. Estudo comparativo a través do psicodiagnóstico de Rorschach entre crianças criadas em instituições e em família. Pediatria (São Paulo) 1985; 7: 25-9.

Carvalho AM. Fatores contextuais na emergência do comportamento de cuidado entre crianças. Psicol. Reflex. Crit. 2000; 13(1): 81-8.

Carvalho C. Diagnóstico: abuso infantil. Rev. Bras. Odontol. 2002; 59 (3): 180-3.

Carvalho MCB, Guará IMFR. A família: um sujeito pouco refletido no movimento de luta pelos direitos da criança e do adolescente. Rev. Bras. Cresc. Des. Hum. 1994; IV (1): 45-8.

Célia S. Maus tratos à criança. In: Vanzin AS, Nery MES (organizadoras). Atenção integral à saúde da criança: um enfoque epidemiológico. Porto Alegre: RM\&L Gráfica; 1998. p. 112-6.

Costa Neto MM, Amaral CM, Janiques MA. Algumas propostas para a elaboração de uma política de desenvolvimento de recursos humanos em saúde para o Distrito Federal. Rev. de Saúde do DF 1995 jul./set.; 6(3): 5-12.

Crivellari HMT, Melo COM. Saber fazer: implicações da qualificação. Rev. Adm. Empres. 1989 abr./jun.; 29(2): 47-62.

De Antoni C, Koller SH. A visão de família entre adolescentes que sofreram violência intrafamiliar. Estud. Psicol. (Natal) 2000 Jul./Dez.; 5 (2). 
Dias EMP. Programa de atenção social à maus tratos à criança. In: Vanzin AS, Nery MES (organizadoras). Atenção integral à saúde da criança: um enfoque epidemiológico. Porto Alegre: RM\&L Gráfica; 1998. p. 50-2.

Dias ML. Vivendo em família: relações de afeto e conflito. $7^{a}$ ed. São Paulo: Moderna; 1992.

Escola de Administração de Empresas de São Paulo. Uma chave para a inclusão: Projeto Pró-Vida “A chave do tamanho". In: Escola de Administração de Empresas. Histórias de um Brasil que funciona: governos locais ajudando a construir um país mais justo. São Paulo: Escola de Administração de Empresas de São Paulo; 2000. p. $71-4$.

Faria SO, Stanisci AS. A formação de recursos humanos na política de atenção a crianças e jovens marginalizados. Cad. FUNDAP 1990 set.; 9 (18): 61-7.

Fatheazam S. A empresa de amanhã nos dias de hoje. Rev. Adm. Saúde 2000 abr./jun. 2 (7): 23-5.

Fernandes EC, Gutierrez LH. Qualidade de vida no trabalho (QVT): uma experiência brasileira. Rev. Adm. 1988 out./dez.; 23(4): 29-38.

Feuerwerker LCM, Kalil ME, Baduy RJ. A construção de modelos inovadores de ensino-aprendizagem: as lições aprendidas pela Rede UNIDA. Divulg. Saúde Deb. 2000 dez.; 22: 49-62.

Gil AC. Métodos e técnicas de pesquisa social. $4^{\text {a }}$ ed. São Paulo: Atlas; 1994.

Goffman E. Manicômios, prisões e conventos. $7^{\text {a }}$ ed. São Paulo: Perspectiva; 2001.

Gomide PIC. Sorriso: um indicador de felicidade. Rev. Bras. Cresc. Des. Hum. 1996; 6 (1/2): 39-48. 
Günther IA. Cuidados alternativos em crianças e seus efeitos no desenvolvimento sócio-emocional. Est. Psicol. 1988 jan./jul.; (1): 74-92.

Junqueira MFPS, Deslandes SF. Resiliência e maus-tratos à criança. Cad. Saúde Pública 2003 jan./fev.; 19(1): 227-35.

Klaus $\mathrm{MH}$, Kennell JH, Klaus $\mathrm{PH}$. Vínculo: construindo as bases para um apego seguro e para a independência. Porto Alegre: Artmed; 2000. p. 168-80.

Kosminski EV. Internados: os filhos do estado padrasto. In: Martins JS. O massacre dos inocentes: a criança sem infância no Brasil. $2^{\text {a }}$ ed. São Paulo: Hucitec; 1993. p. $155-80$.

Leite MP, Posthuma AC. Reestruturação produtiva e qualificação: reflexões sobre a experiência brasileira. São Paulo Perspect. 1996; 10(1): 63-76.

Lenzi MM, Corrêa LB. Qualidade de vida no trabalho: uma experiência possível. Divulg. Saúde Deb. 2000 nov.; 19: 24-9.

Lordelo ER. O papel do adulto e da criança como parceiros do desenvolvimento em Vygotsky. Rev. Bras. Cresc. Desenv. Hum. 1998; 8(1/2): 26-32.

Lyra J, Medrado B, Nascimento P, Galindo D, Moraes M, Pedrosa C. “A gente não pode fazer nada, só podemos decidir sabor de sorvete". Adolescentes: de sujeito de necessidades a um sujeito de direitos. Cad. CEDES 2002 ago.; 22(57): 9-21.

Maia FB. Limites: o fundamento de uma boa educação. Rev. Psicol. Argumento 1998 abr.; (XXII): 95-100.

Marcilio ML. A roda dos expostos e a criança abandonada na história do Brasil. 1726-1950. In: Freitas MC, organizador. História social da infância no Brasil. $4^{\mathbf{a}}$ ed. São Paulo: Cortez; 2001. p. 53-79. 
Marconi MA, Lakatos EM. Técnicas de pesquisa: planejamento e execução de pesquisas, amostragens e técnicas de pesquisas, elaboração, análise e interpretação de dados. $3^{\text {a }}$ ed. São Paulo: Atlas; 1996.

Martinez MC, Paraguay AIBB. A análise ergonômica do trabalho no estudo das relações entre os fatores psicossociais e a satisfação no trabalho. In; ABERGO. Anais ABERGO 2001; [cd-rom]. s.1, s.n, 2001. p.1-7.

Martinez MC, Paraguay AIBB, Latorre MRDO. Relação entre satisfação com aspectos psicossociais e saúde dos trabalhadores. Rev. Saúde Pública 2004 fev.; 38(1): 55-61.

Martins Neto AC. O conto joãozinho e mariazinha como instrumento para avaliar o sentimento de rejeição em crianças de ambiente familiar e institucional. São Paulo; 2001. [Dissertação de Mestrado - Universidade Presbiteriana Mackenzie].

Mauro MYC. A criança no núcleo familiar e no contexto comunitário: uma abordagem de enfermagem. In: Vanzin AS, Nery MES (organizadoras). Atenção integral à saúde da criança: um enfoque epidemiológico. Porto Alegre: RM\&L Gráfica; 1998. p. 55- .

Medeiros M, Ferriani MGC, Gomes R, Munari DB. O significado de casa e rua para meninos com experiência de vida nas ruas: em busca de uma compreensão sobre as implicações para a saúde. Rev. Bras. Cresc. Desenv. Hum. 2002; 12(2): 1-12.

Mello SL. Estatuto da criança e do adolescente: é possível torná-lo realidade psicológica? Psicol. USP 1999; 10 (2).

Menezes A. Pais permissivos - filhos “problema”. Rio de janeiro: Artes \& Contos; 1995. 
MNMMR - Movimento Nacional de Meninos e Meninas de Rua. Conheça o movimento [on line]. Disponível em <http://www.mnmmr.org.br $>$ [4 out 2004]

Monteiro MCN, Cabral MAA, Morgado AF. Aspectos psicossociais de pais agressores. J. Bras. Psiq. 1995; 44(1): 7-13.

Morin EM. Os sentidos do trabalho. Rev. Adm. Empres. 2001 jul./set.; 41(3): 8-19.

Nery CB. Atenção de enfermagem à mãe e à criança. In: Vanzin AS, Nery MES (organizadoras). Atenção integral à saúde da criança: um enfoque epidemiológico. Porto Alegre: RM\&L Gráfica; 1998. p. 29- .

Papalia DE, Olds SW. O mundo da criança. Trad de MLGL Rosa. $2^{a}$ ed. São Paulo: Markon Books; 1998.

Pelicioni, MCF. Educação em saúde e educação ambiental: estratégias de construção da escola promotora da saúde. São Paulo; 2000. [Tese de Livre Docência - Faculdade de Saúde Pública da USP].

Pelicioni MCF. Qualidade de vida das mulheres trabalhadoras das creches conveniadas do bairro Bela Vista do município de São Paulo. São Paulo; 1995. [Tese de Doutoramento - Faculdade de Saúde Pública da USP].

Pernetta C. Terapêutica pediátrica. $7^{\mathrm{a}}$ ed. Rio de Janeiro: Atheneu; 1982.

Pino A. Direitos e realidade social da criança no Brasil a propósito do "Estatuto da Criança e do Adolescente". Educ. Sociedade 1990 ago.; (36): 61-79.

Reis CA. Casa-abrigo e escola: um estudo exploratório. São Paulo; 2001. [Dissertação de Mestrado - Universidade Presbiteriana Mackenzie]. 
Roque EMST, Ferriani MGC. Desvendando a violência doméstica contra crianças e adolescentes sob a ótica dos operadores do direito na comarca de Jardinópolis - SP. Rev. Latino-Am. Enferm. 2002 mai./jun.; 10(3): 334-44.

Santana JSS. O processo de exclusão de adolescentes no Brasil: sua origem na infância desvalorizada. In: Ramos FRS, Monticelli M, Nitschke RG, organizadoras. Projeto acolher: um encontro da enfermagem com o adolescente brasileiro. Brasília: ABEn / Governo Federal; 2000. p. 15-36.

Santos MF, Bastos ACS. Padrões de interação entre adolescentes e educadores num espaço institucional: resignificando trajetórias de risco. Psicol. Reflex. Crit. 2002; 15(1): 45-52.

Sebastiani RW. O adolescente em situação de risco social: uma intervenção para promoção de saúde. São Paulo; 2004. [Dissertação de Mestrado - Faculdade de Saúde Pública da USP].

Silva AL, Vogel C, Virgílio MS. Significados de cuidado para crianças e adolescentes vítimas da violência doméstica. Rev. Bras. Enferm. 2001 jan./mar.; 54 (1): 48-62.

Silva R. Os filhos do governo. São Paulo: Ática; 1997.

Siqueira MMM, Coleta JAD. Metodologia para investigação da qualidade de vida no trabalho. Arq. Bras. Psicol. 1989 ago.; 41(3): 51-66.

Souza Neto JC. Crianças e adolescentes abandonados: estratégias de sobrevivência. $2^{\mathrm{a}}$ ed. São Paulo: Arte Impressa; 2002. p. 91-172.

Souza Neto JC. História da criança e do adolescente no Brasil. Rev. Unifieo 2000 junho: 103-15. 
Tamoyo A. Prioridades axiológicas e satisfação no trabalho. Rev. Adm. 2000 abr./jun.; 35(2): 37-47.

Tamoyo A. Valores organizacionais: sua relação com satisfação no trabalho. cidadania organizacional e comprometimento afetivo. Rev. Adm. 1998 jul./set.; 33(3): 56-63.

Vieira A. A abordagem sócio-técnica e os programas de qualidade de vida no trabalho. Psic. Rev. São Paulo 1997; (4): 73-90.

Vives EW. Família, sistema básico de estimulação para o bebê. Rev. Psicol. Argumento 1995 abril: 67-74.

Wagner A, Ferreira VS, Rodrigues MIM. Estratégias educativas: uma perspectiva entre pais e filhos. Rev. Psicol. Argumento 1998 out.; (XXIII): 37-46.

Weber LND. A ficção e a realidade de crianças institucionalizadas: uma proposta de intervenção. Rev. Texto \& Contexto 1999 maio/ago.; 8 (2): 427-30.

Weber LND. Crianças sem família no Brasil. [Apresentado no XXVI Congrès International de Psychologie; 1996a out. 16 a 21; Montreal (Canadá)].

Weber LND. Da institucionalização à adoção: um caminho possível? Rev. Igualdade 1995 dez.; 9: 1-9.

Weber LND, Kossobudski LHM. Filhos da solidão: institucionalização, abandono e adoção. Curitiba: Governo do estado do Paraná; 1996b. 211 p. [Resenha de C Amorim, JCF Turbay, LAB Canuto. Rev. Psicol. Arg. 1997 abr.; (XX): 77-85].

Wendland J. A abordagem clínica das interações pais-bebê: perspectivas teóricas e metodológicas. Psicol. Reflex. e Crit. 2001; 14(1): 45-56. 
Winnicott DW. Privação e delinqüência. Trad. de A Cabral. $3^{a}$ ed. São Paulo: Martins Fontes; 1999. A criança desapossada e como pode ser compensada pela falta de vida familiar; p. 195-213.

Zagury T. O adolescente por ele mesmo. Rio de Janeiro: Record; 1996. Na atitude dos pais, a construção do cidadão do futuro; p. 241-4. 


\section{ANEXOS}




\section{ANEXO 1 \\ Declaração Universal dos Direitos da \\ Criança

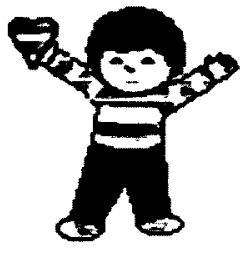

\section{Proclamada pela Assembléia das Nações Unidas}

\section{no dia 2 de novembro de 1959}

Principio I - A criança desfrutará de todos os direitos enunciados nesta Declaração. Estes direitos serão outorgados a todas as crianças, sem qualquer exceção, distinção ou discriminação por motivos de raça, cor, sexo, idioma, religião, opiniōes politicas ou de outra natureza, nacionalidade ou origem social, posição econômica, nascimento ou outra condição, seja inerente à própria criança ou à sua familia.

Princípio II - A criança gozará de proteção especial e disporá de oportunidade e serviços, a serem estabelecidos em lei por outros meios, de modo que possa desenvolver-se física, mental, moral, espiritual e socialmente de forma saudável e normal, assim como em condições de liberdade e dignidade. Ao promulgar leis com este fim, a consideração fundamental a que se atenderá será o interesse superior da criança.

Principio III - A criança tem direito, desde o seu nascimento, a um nome e a uma nacionalidade.

Princípio IV - A criança deve gozar dos beneficios da previdência social. Terá direito a crescer e desenvolver-se em boa saúde; para essa finalidade deverão ser proporcionados, tanto a ela, quanto à sua mãe, cuidados especiais, incluindo-se a alimentação pré e pós-natal. A criança terá direito a desfrutar de alimentação, moradia, lazer e serviços médicos adequados.

Principio V - A criança física ou mentalmente deficiente ou aquela que sofre de algum impedimento social deve receber o tratamento, a educação e os cuidados especiais que requeira o seu caso particular. 
Princípio VI - A criança necessita de amor e compreensão, para o desenvolvimento pleno e harmonioso de sua personalidade; sempre que possivel, deverá crescer com o amparo e sob a responsabilidade de seus pais, mas, em qualquer caso, em um ambiente de afeto e segurança moral e material; salvo circunstâncias excepcionais, não se deverá separar a criança de tenra idade de sua mãe. A sociedade e as autoridades públicas terão a obrigação de cuidar especialmente do menor abandonado ou daqueles que careçam de meios adequados de subsistência. Convém que se concedam subsídios governamentais, ou de outra espécie, para a manutenção dos filhos de familias numerosas.

Princípio VII - A criança tem direito a receber educação escolar, a qual será gratuita e obrigatória, ao menos nas etapas elementares. Dar-se-á à criança uma educação que favoreça sua cultura geral e lhe permita - em condiçōes de igualdade de oportunidades

- desenvolver suas aptidōes e sua individualidade, seu senso de responsabilidade social e moral. Chegando a ser um membro útil à sociedade. O interesse superior da criança deverá ser o interesse diretor daqueles que têm a responsabilidade por sua educação e orientação; tal responsabilidade incumbe, em primeira instância, a seus pais. A criança deve desfrutar plenamente de jogos e brincadeiras, os quais deverão estar dirigidos para educação; a sociedade e a autoridades públicas se esforçarão para promover o exercício deste direito.

Princípio VIII - A criança deve - em todas as circunstâncias - figurar entre os primeiros a receber proteção e auxilio.

Princípio IX - A criança deve ser protegida contra toda forma de abandono, crueldade e exploração. Não será objeto de nenhum tipo de tráfico. Não se deverá permitir que a criança trabalhe antes de uma idade mínima adequada; em caso algum será permitido que a criança dedique-se, ou a ela se imponha, qualquer ocupação ou emprego que possa prejudicar sua saúde ou sua educação, ou impedir seu desenvolvimento físico, mental ou moral.

Principio X - A criança deve ser protegida contra as práticas que possam fomentar a discriminação racial, religiosa ou de qualquer outra indole. Deve ser educada dentro de um espirito de compreensão, tolerância, amizade entre os povos, paz e fraternidade universais e com plena consciência de que deve consagrar suas energias e aptidões ao serviço de seus semelhantes. 


\section{ANEXO 2}

Entrevista $n^{\circ}: \quad$ Pesquisa: "Entidades de Abrigo do Municipio de Vitória-ES

\section{Roteiro de Entrevista para o Responsável}

\section{Módulo I - IDENTIFICAÇĀO DO ABRIGO}

1. Identificação do Abrigo:

2. Endereço?

3. Bairro:

6. CEP:

4. Cidade:

7. Telefone/Fax:

5. Estado:

8. E-mail:

9. Data de fundação:

10. Quem é o responsável pelo abrigo (Nome)?
11. Sexo: ( )F ( )M
12. Escolarização:

13. Profissão:

15. Função que exerce no Abrigo:

14. Há quanto tempo trabalha neste Abrigo?

16. Há quanto tempo exerce essa função?

17. O Abrigo é regularmente constituído? ( ) Sim ( ) Não

18. O Abrigo possui Regimento Interno? ( ) Sim ( ) Não

19. Está registrado no Conselho Municipal de Direitos da Criança e do Adolescente?

( ) Sim. ( ) Não

20. Qual a classificação desse abrigo quanto organização na sociedade?
( ) ONG de natureza religiosa
( ) ONG de natureza laica
( ) Governamental

21. Quem são as Entidades mantenedoras?

( ) Subvenção de alguma Secretaria (Estadual ou Municipal). Qual?

( ) Contribuições de associados ( ) Contribuições de doadores espontâneos ( ) ONG's

( ) Outros.

22. Qual é o público atendido por esse Abrigo? ( ) Crianças de 0 a 5 anos ( ) Crianças de 6 a

12 anos ( ) Adolescentes de 13 a 18 anos Obs.:

23. Como são caracterizadas as crianças/adolescentes atendidos nesse Abrigo?
( ) Portador de excepcionalidade mental
( ) Portador de virus HIV
( ) Abandonados
( ) Portador de necessidades físicas especiais
( ) Vitimas de maus tratos/negligência
( ) Outros. Especificar:

24. Qual é o sexo das crianças abrigadas: ( ) Masculino ( ) Feminino ( ) Ambos

25. Qual é a capacidade total de atendimento do Abrigo?

26. Qual é o $n^{\circ}$ de crianças/adolescentes atendidos no momento da entrevista?

27. Documentação exigida pelo Abrigo: ( ) Certidão de nascimento

( ) Cartão de vacina

( ) Comprovante de freqüéncia a escola ( ) Outros.

( ) náo é exigida documentação alguma

28. Existem prontuários individualizado das crianças/adolescentes atendidos pelo Abrigo?

( ) Sim ( ) Não

29. Que documentos fazem parte de prontuário? 
30. Como se dá o encaminhamento para este Abrigo? ( ) Conselho Tutelar Judiciária ( )Familia ( ) Outros. Especificar:

31. Quais categorias profissionais constam no quadro de funcionários do Abrigo? (Citar o número de profissionais)

( ) Médico

Profissionais

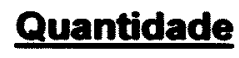

\section{Profissionais}

( ) Profissional Administrativo

( )Autoridade

( ) Enfermeiro

( ) Psicólogo

( ) Assistente Social

( ) Dentista

( ) Pedagogo/Professor

( ) Educador/ Monitor

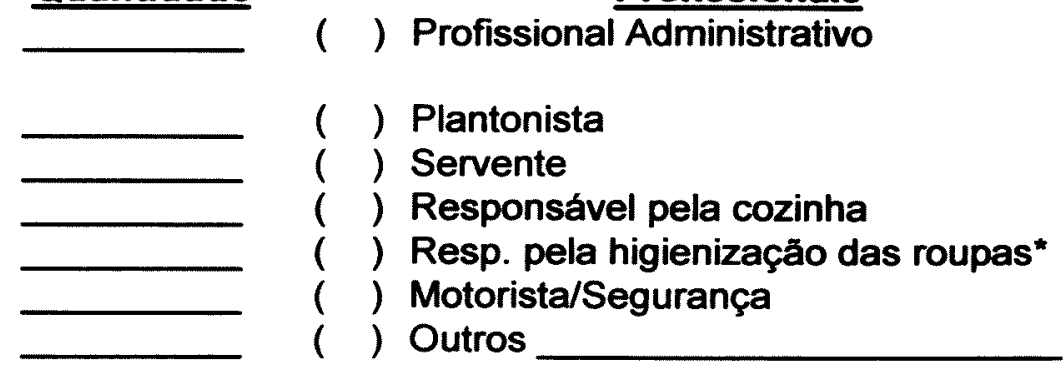

Quantidade

* roupas de cama, mesa e banho, e de uso pessoal.

Módulo II - PLANO DE TRABALHO (Art. 92, ECA) - Proposta Sócio-Educativa

32. Como é a rotina do Abrigo?

33. Existe um plano de trabalho escrito, redigido de forma clara e explícita, compativel com os princípios do Estatuto da Criança e do Adolescente? ( ) Sim ( ) Não

34. Se sim, quem participa dessa elaboração do plano de trabalho?
( ) Diretoria/responsável pelo Abrigo
( ) Equipe técnica
( ) Crianças/adolescentes ( ) Entidade ( ) Outros
( ) Comunidade

35. O Abrigo realiza reuniōes com a equipe de funcionários para discutir sobre o Estatuto da Criança e do Adolescente, ou qualquer outra legislação referente à criança e ao adolescente, com o objetivo de aprimorar o conhecimento? ( ) Sim ( ) Não

36. Há plano individual de atendimento? ( ) Sim ( ) Não

37. As crianças/adolescentes participam da elaboração do plano individual de atendimento?

( ) $\operatorname{Sim}($ ) Não

38. Quais são os atendimentos oferecidos pelo Abrigo?

MO ABRIGO

\section{FORA DO}

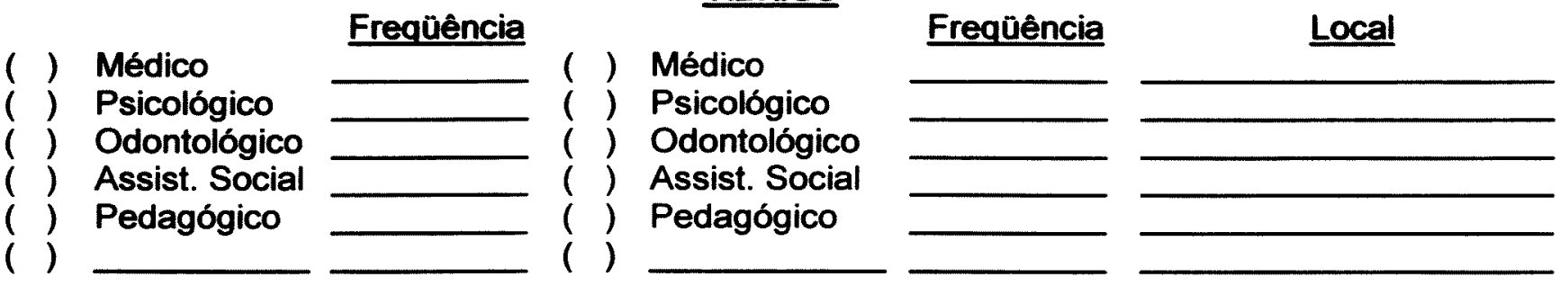

39. Qual é o tipo de vestuário usado pelas crianças/adolescentes? ( ) Uniforme ( ) Outros trajes

40. Existem armários com compartimentos individualizados? （） Sim （）Não 
41. Existe um processo de recepção e acolhimento das crianças/adolescentes no Abrigo?

( ) $\operatorname{Sim}($ ) Não

42. Como é realizado?

43. Há transferência de crianças/adolescentes deste para outros Abrigos?

( ) Sim. Por que?

Freqüência:

( ) Năo

44. Vocês já receberam crianças/adolescentes vindas de outros Abrigos?

( ) Sim.Por que?

Freqüência:

( ) Não

45. Como se dá a participação dos pais/familiares no Abrigo?

46. Há algum programa de incentivo a preservação dos vínculos familiares?（） Sim （）Não 47. Se sim, quais?

48. Qual a postura do Abrigo quando encaminhado grupos de irmãos?

49. São desenvolvidas atividades para envolver a comunidade? （） Sim （）Não

50. Quais?

51. Săo realizadas atividades de esporte?
( ) Sim. Freqüência?
( ) Não

52. São realizadas atividades de cultura e lazer?

( ) Sim. Freqüência?

( ) Não

53. São incentivadas práticas religiosas? ( ) Sim ( )Não

54. Quais?

55. Todas as crianças/adolescentes freqüentam a escola? （）Sim （）Não Por que?

56. São desenvolvidos programas que estimulem a adoção daquelas crianças/adolescentes diante da impossibilidade da reaproximação com a familia de origem? ( ) Sim ( ) Não

57. Quais?

58. Qual o tempo médio de permanência das crianças/adolescentes neste Abrigo? 
59. Existe avaliação da situação das crianças/ adolescentes (Estudo de caso)? ( ) Sim ( ) Não

60. Existe programa de preparação para o desligamento da criança/adolescente?

( ) $\operatorname{Sim}$ ( ) Não

Como se dá essa preparação?

61. Existe acompanhamento de egresso? ( ) Sim （） Não

62. Se sim, como é desenvolvido?

Impressões do observador: 


\section{ANEXO 3}

Entrevista no:

Pesquisa: Entidades de Abrigos do Municipio de Vitória-ES"

Data: I_ Entrevistador:

\section{Roteiro de Entrevista para o Funcionário}

1. Identificação do Abrigo:

2. Iniciais do Nome:

5. Qual a função que exerce no Abrigo? 3. Sexo: ( )F ( ) M 4. Idade:

6. Há quanto tempo exerce essa função?

7. Qual a sua carga horária de trabalho?

8. Qual a sua relação de trabalho?

( ) Servidor público. Especificar:

( ) Contratado pela CLT

( ) Voluntário (Federal/Estadual/Municipal)

( ) Outro. Especificar:

9. Qual o seu grau de instrução?

( ) Não alfabetizado

( ) Alfabetizado

( ) Assina o nome

( ) $5^{\mathrm{a}}$ a $8^{\mathrm{a}}$ série

( ) $1^{\mathrm{a}}$ a $4^{\mathrm{a}}$ série

( ) Superior Incom

( ) Ensino Médio

Especificar o curso:

( Superior Completo. Especificar o curso:

( ) Pós-graduação lato-senso. Especificar o curso:

( ) Pós-graduação strictu-senso. Especificar o curso:

10. Que outros cursos você já freqüentou?

( ) nenhum ( ) Informática

( ) Lingua estrangeira

( ) Outro

11. Que atividades você desenvolve no Abrigo?

12. Com que freqüência você tem contato com as crianças/adolescentes?

( ) Diariamente

( ) Mensalmente

( ) Semanalmente

( ) Outro

13. Você participou da elaboração do plano de trabalho do Abrigo?

( ) Năo há plano de trabalho ( ) Sim ( ) Não

14. Vocé participa das reuniōes de estudo do ECRIAD da equipe?

( ) Não há ( ) Sim ( ) Não

15. Como você participa do acolhimento das crianças/adolescentes que chegam ao Abrigo? ( ) Nảo há. 
16. Qual a participação das crianças/adolescentes na execução das tarefas diárias do Abrigo?

17. Você participa da avaliação da situação das crianças/ adolescentes (Estudo de caso)?

( ) Não há avaliação.

( ) Sim. Como?

( ) Não. Por que?

18. Você participa das atividades que o Abrigo desenvolve junto com a comunidade?

( ) Não são desenvolvidas atividades com a comunidade ( ) Sim ( ) Não

19. Você participa do programa de preparação para o desligamento da criança/adolescente?

( ) Não há programa de preparação para desligamento.

( ) Sim. Como?

( ) Não. Por que?

20. O que você entende por saúde?

21. Quais são as principais queixas das crianças e adolescentes em relação à saúde física?

22. Quais são as principais queixas das crianças e adolescentes em relação a questōes afetivas?

23. Qual sua postura diante dos problemas relatados pelas crianças?

24. Quais são os problemas de saúde que as crianças e adolescentes mais apresentam?

25. De que forma você contribui para a saúde da criança/adolescente?

26. Você está satisfeito(a) com o trabalho que desenvolve no Abrigo?（） Sim （） Não Por que?

27. Quais são as dificuldades encontradas no exercício de sua função?

28. Quais săo os motivos dessas dificuldades? 
29. O que você sugere para melhorar as condições de trabalho?

30. Você considera necessário o desenvolvimento de um programa de formação continuada?

( ) Sim ( ) Não

Por que?

31. Que conhecimentos você gostaria de adquirir para melhorar a execução de suas atividades?

32. Que temas você sugere para um curso de formação continuada?

33. O que o levou a trabalhar em um Abrigo?

34. O que Ihe mantém trabalhando em um Abrigo?

35. Como você vê o seu desenvolvimento profissional dentro do abrigo?

36. Como você avalia o Abrigo nos seguintes itens:

\begin{tabular}{|c|c|c|c|}
\hline & BOM & REGULAR & INSATISFATÓRIO \\
\hline Instalações físicas & & ( ) & ( ) \\
\hline Higiene & () & ( ) & ( ) \\
\hline Ventilação & $(1)$ & ( ) & ( ) \\
\hline Iluminação & ( ) & ( ) & ( ) \\
\hline Segurança & ( ) & ( ) & ( ) \\
\hline Plano de Trabalho & $(j)$ & ( ) & ( ) \\
\hline
\end{tabular}

37. Como você avalia as seguintes relações interpessoais:

Sua com a Direção

Sua com a Coordenação

Sua com as crianças/adolescentes

Sua com os outros funcionários

Da Direção com as crianças/adolescentes

Da Coordenação com as crianças/adolescentes

Dos outros funcionários com as

crianças/adolescentes

Da Coordenação com os funcionários

BOM REGULAR RUIM NÃO SE APLICA

Impressões do observador: 


\section{ANEXO 4}

\section{PROPOSTA DE CURSO}

NOME: Formação básica para profissionais de entidades de abrigo DURAÇÃO: 6 meses

PERIODICIDADE: um encontro mensal

CARGA HORÁRIA TOTAL: 24 horas

PROGRAMAÇÃo:

\begin{tabular}{|l|c|}
\hline \multicolumn{1}{|c|}{ Tema } & Carga horária \\
\hline Serviço Social & $4 \mathrm{~h}$ \\
\hline Psicologia & $8 \mathrm{~h}$ \\
\hline Saúde & $8 \mathrm{~h}$ \\
\hline Educação & $4 \mathrm{~h}$ \\
\hline
\end{tabular}

\section{CONTEÚDOS:}

AREA DE SERVIÇO SOCIAL:

- Estatuto da Criança e do Adolescente (ECA);

- direitos humanos;

- políticas públicas;

- responsabilidade social;

- assistência social;

- crianças e adolescentes institucionalizados;

- outros de interesse dos profissionais.

ÁREA DE PSICOLOGIA:

- relações interpessoais;

- socialização;

- identidade;

- família;

- rejeição;

- violência;

- preconceito;

- desenvolvimento infantil;

- adolescência;

- relacionamento com crianças e adolescentes;

- acolhimento;

- limites;

- outros de interesse dos profissionais. 
AREA DE SAÚDE:

- conceito de saúde;

- SUS;

- ciclos de vida;

- higiene e cuidados;

- medicamentos;

- primeiros socorros;

- portadores de necessidades especiais;

- drogas / dependência química;

- sexualidade;

- AIDS e outras DSTs;

- outros de interesse dos profissionais.

AREA DE EDUCAÇÃO:

- educação da criança e do adolescente;

- papel do educador;

- pedagogias de intervenção;

- alfabetização especial;

- outros de interesse dos profissionais.

\section{METODOLOGIA:}

- Aulas expositivas dialogadas;

- Dinâmicas em grupo.

\section{RECURSOS DIDÁTICOS:}

- Quadro branco e canetas para quadro branco;

- Retroprojetor;

- Datashow;

- Materiais necessários às dinâmicas em grupo.

\section{AVALIAÇÃO:}

- Será aplicado um instrumento antes do início de cada encontro para se verificar os conhecimentos prévios sobre os temas que serão abordados no dia.

- Ao final de cada encontro será aplicado um segundo instrumento com o objetivo de averiguar a contribuiçăo do encontro, em termos de conhecimentos adquiridos.

- Será realizada avaliação do curso por meio de instrumento com questões abertas e serão solicitadas sugestōes para a continuidade do programa.

OBS.: Antes da operacionalização do curso, a proposta será apresentada aos profissionais dos abrigos para verificação do atendimento às suas necessidades e sugestões. 